DENISE DA SILVA REIS

\title{
AVALIAÇÃO DA EXPRESSÃO DA ENZIMA INDOLEAMINA 2,3-DIOXIGENASE (IDO) EM MONÓCITOS E CÉLULAS DENDRÍTICAS DERIVADAS DE MONÓCITOS DE INDIVÍDUOS INFECTADOS PELO HIV
}

Dissertação apresentada ao Programa de PósGraduação em Imunologia do Instituto de Ciências Biomédicas da Universidade de São Paulo, para obtenção do Título de Mestre em Ciências. 


\title{
DENISE DA SILVA REIS
}

\section{AVALIAÇÃO DA EXPRESSÃO DA ENZIMA INDOLEAMINA 2,3- DIOXIGENASE (IDO) EM MONÓCITOS E CÉLULAS DENDRÍTICAS DERIVADAS DE MONÓCITOS DE INDIVÍDUOS INFECTADOS PELO HIV}

\author{
Dissertação apresentada ao Programa de Pós- \\ Graduação em Imunologia do Instituto de \\ Ciências Biomédicas da Universidade de São \\ Paulo, para obtenção do Título de Mestre em \\ Ciências. \\ Área de concentração: Imunologia \\ Orientadora: Dra. Telma Miyuki Oshiro \\ Sumida \\ Versão original
}


DADOS DE CATALOGAÇÃO NA PUBLICAÇÃO (CIP)

Serviço de Biblioteca e Informação Biomédica do

Instituto de Ciências Biomédicas da Universidade de São Paulo

(ㄱ) reprodução total

Reis, Denise da Silva.

Avaliação da expressão da enzima indoleamina 2,3-dioxigenase (IDO) em monócitos e células dendríticas derivadas de monócitos de indivíduos infectados pelo HIV / Denise da Silva Reis. -- São Paulo, 2015.

Orientador: Profa. Dra. Telma Miyuki Oshiro.

Dissertação (Mestrado) - Universidade de São Paulo. Instituto de Ciências Biomédicas. Departamento de Imunologia. Área de concentração: Imunologia. Linha de pesquisa: Imunoterapia anti-HIV.

Versão do título para o inglês: Evaluation of indoleamine 2,3dioxygenase (IDO) expression in monocytes and monocyte derived dendritic cells of HIV patients.

1. IDO 2. Células dendriticas 3. HIV 4. Monócitos I. Oshiro, Profa. Dra. Telma Miyuki II. Universidade de São Paulo. Instituto de Ciências Biomédicas. Programa de Pós-Graduação em Imunologia III. Título. 
Candidato(a):

Título da Dissertação:

Avaliação da expressão da enzima indoleamina 2,3dioxigenase (IDO) em monócitos e células dendríticas derivadas de monócitos de indivíduos infectados pelo HIV.

Orientador(a):

Profa. Dra. Telma Miyuki Oshiro.

A Comissão Julgadora dos trabalhos de Defesa da Dissertação de Mestrado, em sessão pública realizada a considerou
( ) Aprovado(a)
( ) Reprovado(a)

Examinador(a): Assinatura:

Nome:

Instituição:

Examinador(a): Assinatura:

Nome:

Instituição:

Presidente: Assinatura:

Nome:

Instituição: 
São Paulo, 01 de outubro de 2013.

\section{PARECER 1140/CEP}

A Comissão de Ética em Pesquisas em Seres Humanos do ICB, na reunião realizada no dia 25.09.2013, APROVOU o projeto intitulado: "Avaliação da expressão da enzima indoleamina 2,3-dioxigenase (ido) em monócitos e células dendríticas derivadas de monócitos de indivíduos infectados pelo HIV" da pesquisadora Telma Miruki Oshiro Sumida e aluna Denise da SILVA ReIS.

Cabe aos Pesquisadores executantes elaborar e apresentar a este Comitê, relatórios anuais (parciais ou final), de acordo com a resolução 196/06 do Conselho Nacional da Saúde, item IX. 2 letra c. conforme modelo constante no site.icb.usp.br.

Ao pesquisador cabe também finalizar o processo junto à Plataforma Brasil quando do encerramento deste.

O primeiro relatório deverá ser encaminhado à Secretaria deste CEP em 25.09.2014.

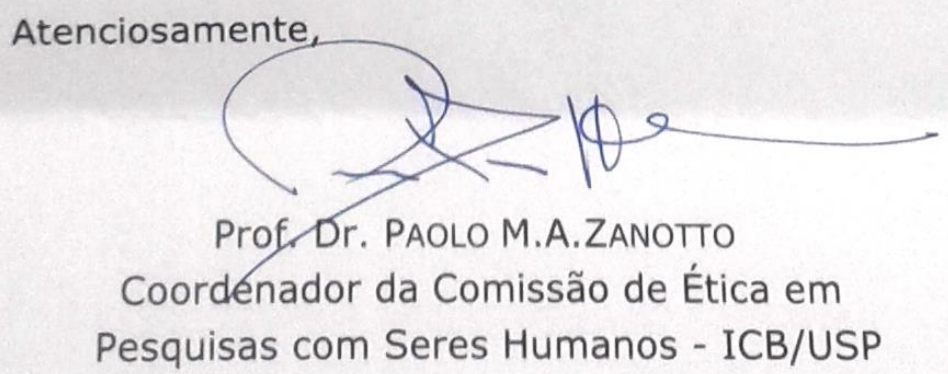


Dedico este trabatho aos mens pais, Salete e Neto, por serem $\sigma$ alicerce que me dá forças para seguir no caminho certo e nunca desistir. 


\section{AGRADECIMENTOS}

Agradeço primeiramente a Deus, por estar presente em mais essa fase da minha vida, me apoiando e me dando forças para seguir em frente.

Agradeço à minha mãe, Salete, por acreditar no meu potencial, ser a minha grande e melhor amiga e por me apoiar em minhas decisões. Ao meu pai, Neto, por fazer com que eu sempre me sinta especial, por limpar minhas lágrimas nos momentos difíceis e me fazer sorrir a cada obstáculo superado. Agradeço aos meus pais por estarem sempre a postos para me amparar em cada tropeço e por vibrarem com cada conquista minha.

Agradeço às minhas amigas Fernanda, Valquíria e Clarissa por me lembrarem de que amizades verdadeiras superam a distância física e ficam cada vez mais fortes e sinceras. Ás minhas antigas companheiras de república Geórgia, Marcela, Laura, Talitha e Amanda que se fizeram presentes em mais esse momento importante e solidificaram uma linda e eterna amizade.

Agradeço à minha orientadora, Dra. Telma Oshiro, que me incentivou, transmitiu seus conhecimentos e contribuiu infinitamente para o meu crescimento profissional e pessoal. Ás minhas companheiras de grupo Laís, Wanessa, Marcela, Nathália, Bruna, Ana Paula, Alana e Edione que me ensinaram que as recompensas de um bom trabalho em equipe vão muito além do espaço físico do laboratório. Vocês estiveram comigo desde o começo, em todos os erros e a cada acerto.

Àqueles que acompanharam o final dessa jornada e que, mesmo de longe, transmitiram seus pensamentos positivos e demonstraram apoio em momentos difíceis, meu muito obrigada.

Agradeço á todos os integrantes do LIM-56 e do departamento de imunologia do Instituo de Ciências Biomédicas da USP pelos ensinamentos compartilhados.

Agradeço aos pacientes pela doação de amostras, compreensão e colaboração. Ao Prof. Dr. Alberto José da Silva Duarte, pela oportunidade de realizar o mestrado. Ao HC-FMUSP e CAPES, pelo auxílio técnico e apoio financeiro.

Muito obrigada a todos! 
"A mente que se abre a uma nova ideia jamais voltará ao seu tamanho original"

(AlbertEinstein) 


\section{RESUMO}

Reis DS. Avaliação da expressão da enzima indoleamina 2,3-dioxigenase (IDO) em monócitos e células dendríticas derivadas de monócitos de indivíduos infectados pelo HIV. [dissertação (Mestrado em Imunologia)]. São Paulo: Instituto de Ciências Biomédicas, Universidade de São Paulo; 2015.

INTRODUÇÃO: Células dendríticas (DCs) constituem uma população fenotípica e funcionalmente heterogênea, podendo ser responsáveis tanto pelas funções imunogênicas quanto pelas tolerogênicas na resposta imune. Neste contexto, um dos mecanismos propostos para diferenciar os perfis imunológicos adotados pelas DCs está relacionado com a expressão da enzima indoleamina 2,3-dioxigenase (IDO), envolvida no processo de regulação da resposta imune. IDO catalisa o primeiro passo de degradação do triptofano, levando à depleção desse aminoácido essencial do microambiente e à formação de metabólitos, inibindo a proliferação de linfócitos T. Durante a infecção pelo HIV, IDO pode suprimir a resposta aos antígenos virais e pacientes cronicamente infectados apresentam redução crônica dos níveis plasmáticos de triptofano e aumento dos níveis de metabólitos, característicos de uma ampla ativação da enzima. No contexto de utilização de vacinas de DCs como alternativa terapêutica para o tratamento de pacientes $\mathrm{HIV}^{+}$, a detecção da enzima IDO pode fornecer informações importantes sobre aspectos fenotípicos e funcionais dessas células, auxiliando o aperfeiçoamento das técnicas atualmente utilizadas. OBJETIVOS: avaliar a expressão de IDO em monócitos e DCs derivadas de monócitos de indivíduos $\mathrm{HIV}^{+}$. MÉTODOS: monócitos e DCs, geradas em três estágios distintos de maturação, foram obtidos a partir de amostras de indivíduos sadios $(\mathrm{n}=5)$ e $\mathrm{HIV}^{+}(\mathrm{n}=10)$ e avaliados por citometria fluxo quanto à expressão de marcadores específicos e presença de IDO. Adicionalmente foram realizados ensaios para análise da expressão de RNAm de IDO por PCR em tempo real. A capacidade das DCs obtidas em estimular linfoproliferação e apresentar antígenos de HIV a linfócitos autólogos foi avaliada por ensaio de cocultivo através da diferenciação de células citotóxicas e produção de citocinas detectadas por citometria de fluxo. RESULTADOS: monócitos de indivíduos sadios e $\mathrm{HIV}^{+}$demonstraram um perfil fenotípico e expressão de IDO semelhantes. DCs ativadas, do grupo de indivíduos infectados pelo HIV, demonstraram expressão mais elevada de IDO em relação às DCs imaturas. DCs de indivíduos $\mathrm{HIV}^{+}$, nos diferentes estágios de ativação, demonstraram expressão mais elevada de IDO com relação aos indivíduos sadios. Além disso, foi possível observar que as DCs imaturas, maduras e pulsadas foram capazes de induzir uma resposta proliferativa e polifuncional de linfócitos autólogos em 24 e 96 horas de cocultivo. CONCLUSÕES: nossos resultados sugerem uma expressão diferencial de IDO entre indivíduos sadios e $\mathrm{HIV}^{+}$, indicando um importante papel da enzima no controle da resposta imune e na patogênese da AIDS.

Palavras-chave: Células dendríticas. HIV. IDO. Monócitos. 


\begin{abstract}
Reis DS. Evaluation of indoleamine 2,3-dioxygenase (IDO) expression in monocytes and monocyte derived dendritic cells of HIV patients. [Masters thesis (Immunology)]. São Paulo: Instituto de Ciências Biomédicas, Universidade de São Paulo; 2015.

INTRODUCTION: Dendritic cells (DCs) are a very phenotypically and functionally heterogeneous population that is responsible for both immunogenic or tolerogenic functions. The properties that characterize the stimulatory or regulatory functions of DCs are not clearly identified and one of the mechanisms currently proposed to differentiate these immunological profiles is related to the expression of the regulatory enzyme indoleamine 2,3-dioxygenase (IDO). IDO catalyzes the first step of the tryptophan degradation, leading to this amino acid depletion and metabolites (kynureninas) formation, inhibiting $\mathrm{T}$ cell proliferation. During HIV infection, IDO can suppress the imune response to viral antigens. In fact, $\mathrm{HIV}^{+}$patients demonstrate chronic reduction in tryptophan plasma levels and an increase in kynureninas levels, indicating a broad IDO activation. In the context of DCs vaccines as a therapeutic alternative for the HIV+ patients, the evaluation of IDO levels can bring information about phenotypic and functional aspects of DCs that can improve current techniques of vaccine production. OBJECTIVES: To evaluate IDO expression in monocytes and monocyte derived dendritic cells (MoDCs) of $\mathrm{HIV}^{+}$patients. METHODS: Monocytes and MoDCs (generated in three different activation stages) were obtained from healthy subjects $(\mathrm{n}=5)$ and $\mathrm{HIV}^{+}$ patients $(\mathrm{n}=10)$ and evaluated by flow cytometry for specific markers expression and IDO presence. Additionally, expression of IDO mRNA was performed by real-time PCR. MoDCs ability in stimulate lymphoproliferation and presenting HIV antigens to autologous lymphocytes was evaluated in coculture assays, through cytotoxic cells differentiation, cytokines and chemokines production by flow cytometry. RESULTS: Monocytes obtained from both healthy donors and $\mathrm{HIV}^{+}$patients showed a similar phenotypic profile and IDO expression. Comparison between immature and activated DCs showed an increased IDO expression in activated DCs in patients group. On the other hand, DCs derived from $\mathrm{HIV}^{+}$ patients at different activation stages showed an increased IDO expression when compared to healthy donors. MoDCs were able to induce lymphoproliferation, cytotoxic cells differentiation, cytokines and chemokines production in 24 and 96 hours of coculture. CONCLUSIONS: Our results suggest a differential expression of IDO between health subjects and $\mathrm{HIV}^{+}$patients, indicating an important role of IDO in the control of the immune response and in the HIV pathogenesis.
\end{abstract}

Keywords: Dendritic cells. HIV. IDO. Monocytes. 


\section{LISTA DE FIGURAS}

Figura 1 Estrutura e genes do HIV

Figura 2 Ciclo replicativo do HIV-1

Figura 3 Resumo esquemático das funções da enzima indoleamina 2,3-dioxigenase (IDO) durante a infecção pelo HIV

Figura 4 Aspecto morfológico e esquema de diferenciação dos monócitos e das DCs de indivíduo infectado pelo HIV

Figura 5 Perfil fenotípico de monócitos

Figura 6 Perfil fenotípico de DCs.

Figura 7 Perfil fenotípico de DCs com base no percentual de expressão de marcadores de caracterização e ativação celular.

Figura 8 Perfil fenotípico de DCs com base na intensidade de fluorescência média de marcadores de caracterização e ativação celular.

Figura 9 Perfil fenotípico de DCs imaturas na presença de HIV inativado e DCs ativadas sob influência de 1-metil-triptofano.

Figura 10 Protocolos de ativação para indução da expressão da enzima IDO.

Figura 11 Produção de citocinas por linfócitos TCD4 citotóxicos estimulados por 24 horas com DCs em diferentes estágios de ativação. 
Figura 12 Análise por citometria de fluxo da expressão da enzima IDO em DCs de indivíduos $\mathrm{HIV}^{+}$

Figura 13 Expressão relativa do RNAm de IDO em monócitos e DCs imaturas.

Figura 14 Expressão relativa do RNAm de IDO em DCs

Figura 15 Resposta linfoproliferativa de células $\mathrm{TCD}^{+}$estimuladas por DCs.

Figura 16 Resposta linfoproliferativa de células $\mathrm{TCD}^{+}$estimuladas por DCs.

Figura 17 Resposta linfoproliferativa de $\mathrm{TCD}^{+}$e $\mathrm{TCD}^{+}$estimuladas com DCs.

Figura 18 Análise booleana de produção mono e polifuncional de mediadores imunológicos por linfócitos $\mathrm{TCD} 4^{+}$e $\mathrm{TCD} 8^{+}$

Figura 19 Produção de mediadores imunológicos por linfócitos TCD4 ${ }^{+}$estimulados por 24 horas com DCs em diferentes estágios de ativação

Figura 20 Produção de mediadores imunológicos por linfócitos TCD4 ${ }^{+}$estimulados por 24 horas com DCs imaturas e DCs imaturas/vírus

Figura 21 Produção de mediadores imunológicos por linfócitos TCD4 ${ }^{+}$estimulados por 24 horas com DCs maduras e DCs maduras/1MT. 
Figura 22 Produção de mediadores imunológicos por linfócitos $\mathrm{TCD}^{+}$estimulados por 24 horas com DCs pulsadas e DCs pulsadas/1MT

Figura 23 Produção de mediadores imunológicos por linfócitos TCD4 ${ }^{+}$estimulados por 96 horas com DCs em diferentes estágios de ativação

Figura 24 Produção de mediadores imunológicos por linfócitos TCD4 ${ }^{+}$estimulados por 96 horas com DCs imaturas e DCs imaturas/virus.

Figura 25 Produção de mediadores imunológicos por linfócitos TCD4 ${ }^{+}$estimulados por 96 horas com DCs maduras e DCs maduras/1MT

Figura 26 Produção de mediadores imunológicos por linfócitos TCD4 ${ }^{+}$estimulados por 96 horas com DCs pulsadas e DCs pulsadas/1MT.

Figura 27 Produção de mediadores imunológicos por linfócitos $\mathrm{TCD} 8^{+}$estimulados por 24 horas com DCs em diferentes estágios de ativação

Figura 28 Produção de mediadores imunológicos por linfócitos $\mathrm{TCD} 8^{+}$estimulados por 24 horas com DCs imaturas e DCs imaturas/virus.

Figura 29 Produção de mediadores imunológicos por linfócitos TCD8 ${ }^{+}$estimulados por 24 horas com DCs maduras e DCs maduras/1MT 
Figura 30 Produção de mediadores imunológicos por linfócitos $\mathrm{TCD}^{+}$estimulados por 24 horas com DCs pulsadas e DCs pulsadas/1MT.

Figura 31 Produção de mediadores imunológicos por linfócitos $\mathrm{TCD} 8^{+}$estimulados por 96 horas com DCs em diferentes estágios de ativação.

Figura 32 Produção de mediadores imunológicos por linfócitos $\mathrm{TCD} 8^{+}$estimulados por 96 horas com DCs imaturas e DCs imaturas/virus

Figura 33 Produção de mediadores imunológicos por linfócitos $\mathrm{TCD}^{+}$estimulados por 96 horas com DCs maduras e DCs maduras/1MT.

Figura 34 Produção de mediadores imunológicos por linfócitos TCD8 ${ }^{+}$estimulados por 96 horas com DCs maduras e DCs maduras/1MT 


\section{LISTA DE TABELAS}

Tabela 1 Caracterização dos indivíduos HIV+ participantes do estudo com relação ao gênero, idade, carga viral plasmática e contagem de células

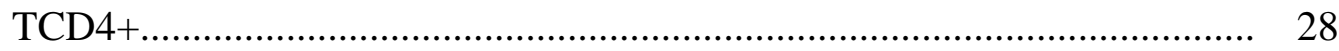

Tabela 2 Caracterização dos indivíduos sadios participantes do estudo com relação ao

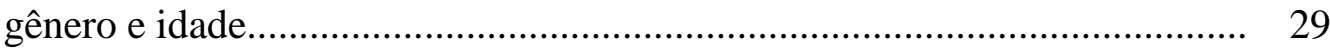




\section{LISTA DE ABREVIATURAS E SIGLAS}

AIDS Síndrome da Imunodeficiência Adquirida (do inglês Acquired Immunodeficiency Syndrome)

APC Célula apresentadora de antígenos (do inglês Antigen Presenting Cell)

ART Terapia antirretroviral (do inglês Antiretroviral Therapy)

AT-2 Aldrithiol-2

BFA Brefeldina A

BSA Albumina sérica bovina (do inglês Bovine Serum Albumin)

CD Cluster of Differentiation

cDNA DNA complementar (do inglês, complementary Deoxyribonucleic Acid)

CFSE Carboxifluoresceina diacetato sucinimidil ester

DC Célula Dendrítica (do inglês Dendritic Cell)

DMSO Dimetilsulfóxido

FSC Foward Scatter

GM-CSF Fator de Crescimento de Colônia de Granulócitos e Macrófagos (do inglês Granulocyte Macrophage Colony Stimulating Factor)

HIV Vírus da Imunodeficiência Humana (do inglês Human Immunodeficiency Virus)

HLA Antígeno Leucocitário Humano (do inglês Human Leucocyte Antigen)

IDO Indoleamina 2,3-dioxigenase (do inglês Indoleamine 2,3-dioxygenase)

IFN Interferon

IL Interleucina

LPS Lipopolissacarídeo

MFI Intensidade de Fluorescência Média (do inglês Mean Fluorescence Intensity) 
MHC Complexo Principal de Histocompatibilidade (do inglês Major Histocompatibility Complex)

MIP Proteína inflamatória de macrófagos (do inglês Macrophage Inflammatory Protein)

MoDC Célula Dendrítica derivada de Monócitos (do inglês Monocyte Derived Dendritic Cell)

NK Natural killer

PBMC Células Mononucleares do Sangue Periférico (do inglês Peripheral Blood Mononuclear Cells)

PBS Tampão Fosfato-Salino (do inglês Phosphate Buffer Saline)

PHA Fitohemaglutinina (do inglês Phytohemagglutinin)

RNA Ácido Ribonucléico (do inglês Ribonucleic Acid)

FBS Soro Fetal Bovino (do inglês Fetal Bovine Serum)

SAB Soro tipo $A B$ humano

SEB Enterotoxina B de estafilococos (do inglês Staphylococcal Enterotoxin B)

SSC Side Scatter

TLR Receptor do tipo Toll (do inglês Toll Like Receptor)

TNF Fator de Necrose Tumoral (do inglês Tumor Necrosis Factor) 


\section{SUMÁRIO}

1 INTRODUÇÃ

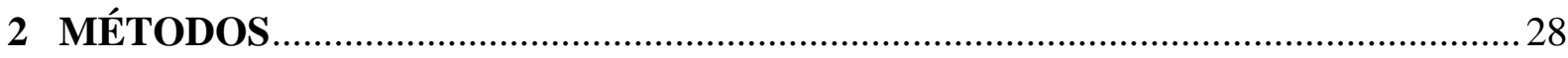

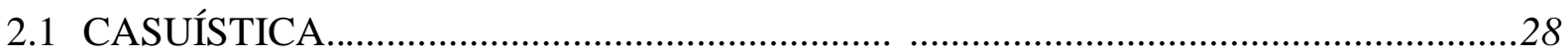

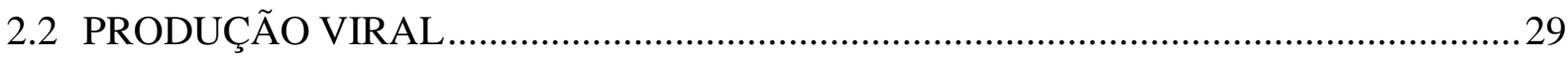

2.3 OBTENÇÃO DE CÉLULAS MONONUCLEARES DE SANGUE PERIFÉRICO (PBMCS)

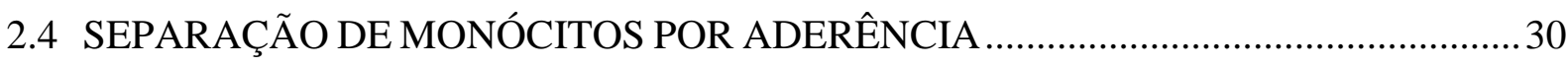

2.5 DIFERENCIAÇÃO DE CÉLULAS DENDRÍTICAS DERIVADAS DE MONÓCITOS

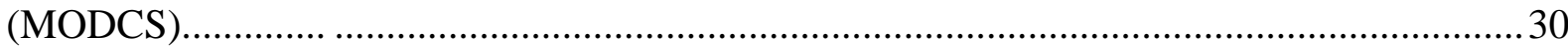

2.6 MARCAÇÃO EXTRACELULAR DE MONÓCITOS E DCS PARA CITOMETRIA DE FLUXO

2.7 MARCAÇÃO INTRACELULAR DE MONÓCITOS E DCS PARA CITOMETRIA DE FLUXO

2.8 QUANTIFICAÇÃO DE RNAM DA ENZIMA IDO - PCR EM TEMPO REAL .............32

2.9 AVALIAÇÃO DA RESPOSTA LINFOPROLIFERATIVA INDUZIDA POR DCs ....33

2.10 AVALIAÇÃO DA POLIFUNCIONALIDADE DE LINFÓCITOS AUTÓLOGOS ESTIMULADOS POR DCS.

2.11 MARCAÇÃO DE LINFÓCITOS PARA ENSAIO DE CITOMETRIA DE FLUXO ... 34

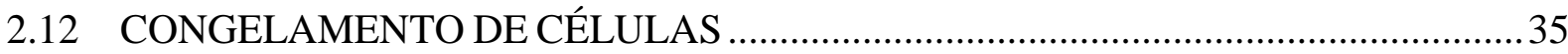

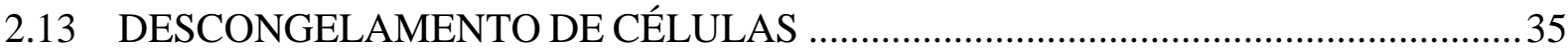

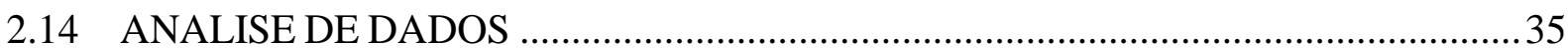

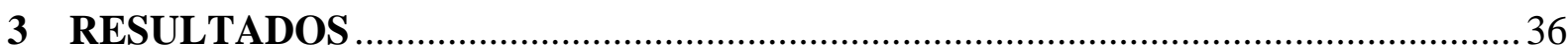

3.1 PERFIL MORFOLÓGICO DE MONÓCITOS E DE DCS ….........................................36 
3.2 PERFIL FENOTÍPICO DE MONÓCITOS

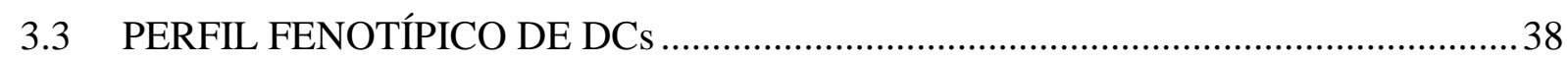

3.4 DETECÇÃO DE IDO EM MONÓCITOS E DCS POR CITOMETRIA DE

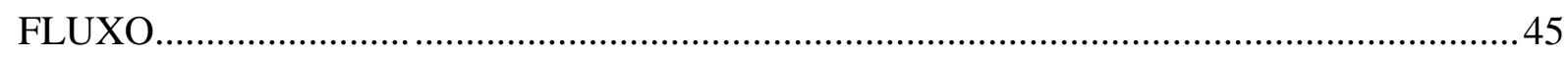

3.5 EXPRESS ÃO DE RNAm DE IDO POR PCR EM TEMPO REAL...............................48

3.6 RESPOSTA LINFOPROLIFERATIVA INDUZIDA DCs ............................................50

3.7 ATIVIDADE POLIFUNCIONAL DE LINFÓCITOS T AUTÓLOGOS

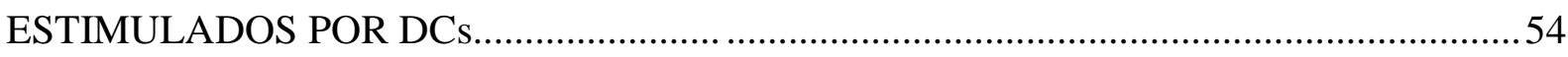

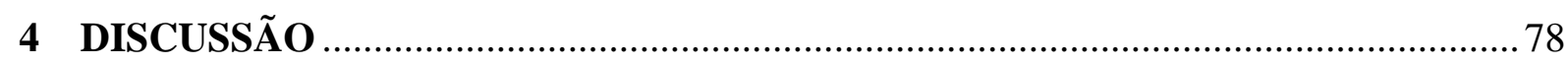

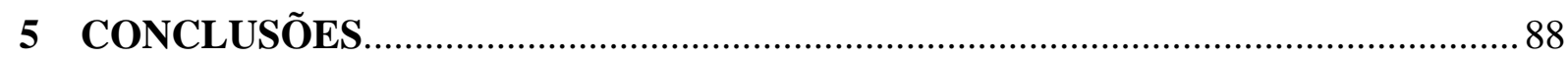

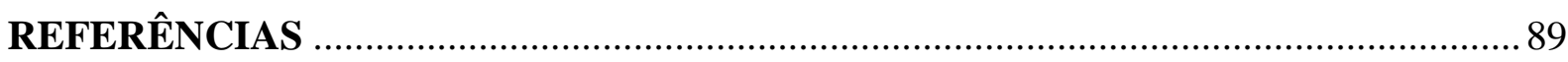

APÊNDICE - CINÉTICA PARA DETERMINAÇÃO DOS TEMPOS DE COCULTIVO ..96 


\section{INTRODUÇÃO}

A infecção causada pelo Vírus da Imunodeficiência Humana (HIV, do inglês Human Immunodeficiency Virus) é um grande problema de saúde pública no mundo. Dados do UNAIDS (Programa Conjunto das Nações Unidas em HIV/AIDS) revelam que cerca de 36,9 milhões de pessoas estavam infectadas pelo HIV em 2014, além disso, ocorreram 2,0 milhões de novos casos de infecção e 1,2 milhões de pessoas morreram devido à síndrome da imunodeficiência adquirida (AIDS, do inglês Acquired Immunodeficiency Syndrome) nesse mesmo ano (1).

O HIV pertence à Família Retroviridae, gênero Lentivirus, um grupo de vírus associado a infecções persistentes, composto de um invólucro formado por uma bicamada lipídica e um capsídeo em forma cônica associado a um genoma viral composto por duas fitas de RNA. O HIV tem seu genoma composto basicamente pelos genes gag, pol e env, que codificam proteínas com funções diversas (figura 1). As proteínas originadas do gene gag compõem a matriz, o capsídeo e o nucleocapsídeo; o gene pol, por sua vez, gera as proteínas com função enzimática, denominadas integrase, protease e transcriptase reversa; e por fim, o gene env codifica as glicoproteínas de membrana gp120 (porção extramembrana) e gp41 (porção transmembrana) (2-5).

Figura 1 - Estrutura e genes do HIV.

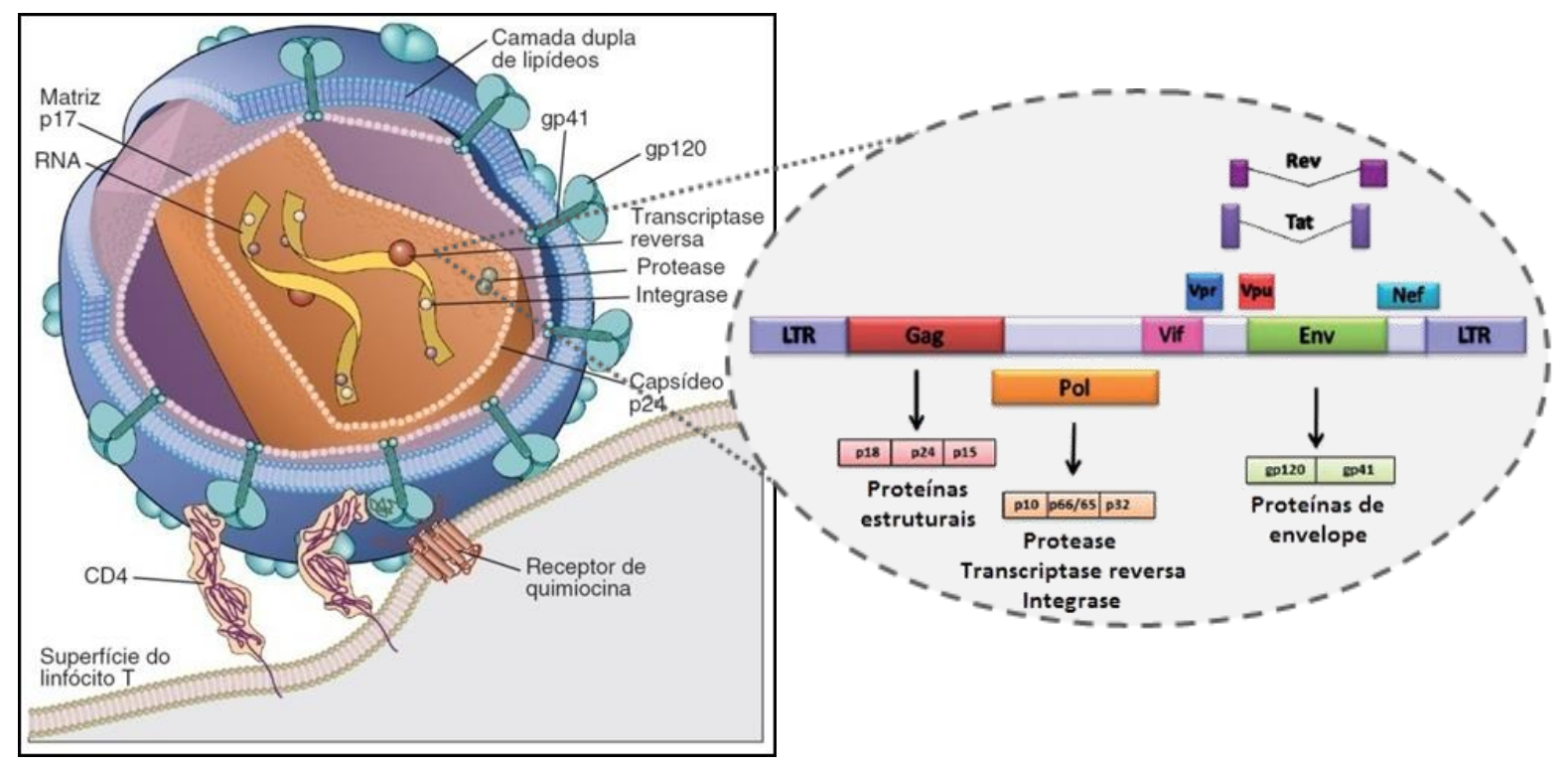

Esquema ilustrativo da estrutura do HIV, moléculas envolvidas no processo de infecção e componentes do genoma viral. (Adaptado de Abbas, 2011 e Arroyave Johanna C et al., 2013). 
A alta taxa de mutação do HIV, resultado da rápida replicação em combinação com uma transcriptase reversa propensa a erros, contribui para a alta variabilidade genética e para o surgimento contínuo de novas variantes virais (6). O HIV utiliza-se de receptores e correceptores presentes principalmente na superfície de linfócitos $\mathrm{T}$, macrófagos e células dendríticas (DCs, do inglês Dendritic Cells), para que haja a ligação e a adsorção viral, proporcionando a infecção celular (figura 2).

Figura 2 - Ciclo replicativo do HIV-1.

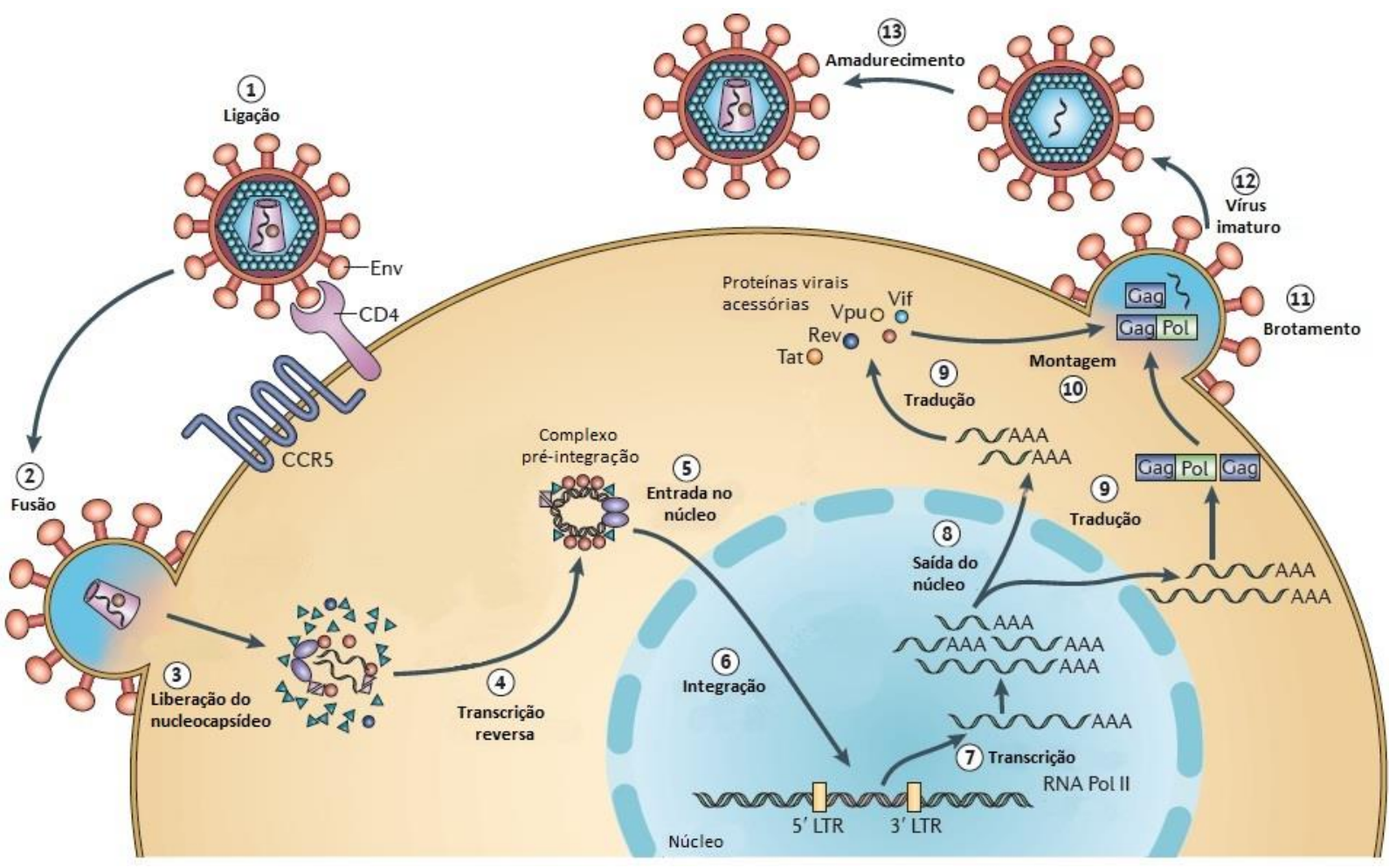

A infecção é iniciada quando glicoproteínas de membrana do envelope ligam-se ao CD4 e ao CCR5/CXCR4 (etapa 1) favorecendo a fusão da membrana do vírus com a membrana da célula hospedeira (etapa 2). Posteriormente ocorre liberação do nucleocapsídeo viral no interior da célula (etapa 3) e, uma vez no citoplasma, ocorre o desnudamento do material genético e a transcrição reversa do RNA viral seguida da entrada do DNA proviral no núcleo (etapa 5), onde o material genético do vírus é integrado ao DNA da célula formando o provírus (etapa 6). A transcrição proviral (etapa 7), mediada pela RNA polimerase II do hospedeiro, gera novos mRNAs que ao saírem do núcleo da célula (etapa 8) são utilizados como fitas molde para a produção de novas proteínas virais (etapa 9). Com os componentes virais prontos, ocorre a montagem do vírus (etapa 10) seguido do brotamento (etapa 11) e liberação de partículas viras imaturas (etapa 12), as quais sofrem o processo de maturação por protease específica quando fora da célula (etapa 13), culminando na geração da partícula viral infecciosa (Adaptado de Elgeman, Cherepanov, 2012). 
A interação ocorre entre os receptores CD4 que estão presentes na membrana da célula alvo e as moléculas gp120 presentes no envelope viral. No entanto, para que haja a ligação e a entrada do HIV na célula hospedeira há necessidade também da interação com correceptores (receptores de quimiocinas) que estão adjacentes aos receptores CD4, sendo as moléculas CCR5 e CXCR4 as mais bem caracterizadas. Após o estabelecimento dessas interações moleculares ocorre fusão do envelope viral com a membrana celular e o nucleocapsídeo viral entra no citoplasma da célula hospedeira para que ocorra o processo de replicação do genoma viral (figura 2) (7).

A infecção pelo HIV causa a ativação crônica do sistema imunológico e a destruição maciça de linfócitos $\mathrm{TCD} 4^{+}$, provocando um profundo comprometimento da resposta imune do hospedeiro que culmina em um quadro de imunossupressão profunda, característico da AIDS (8).

Com a introdução da terapia antirretroviral (ART, do inglês Active Antiretroviral Therapy) nos anos 90, houve uma notável diminuição na mortalidade relacionada à AIDS (9). Os benefícios clínicos decorrentes dessa terapia estão relacionados à efetividade na diminuição da progressão da doença devido à supressão contínua da replicação viral (10). No entanto, efeitos adversos, caracterizados por alterações clínicas e laboratoriais importantes, relacionadas ao uso desta terapia constituem fatores importantes a serem considerados (11). Além das alterações decorrentes da terapia antirretroviral, o aumento de pacientes com falência terapêutica e o reconhecimento de vírus altamente resistentes demandam medidas para reavaliação do tratamento com essas drogas altamente potentes.

Estratégias terapêuticas distintas têm sido desenvolvidas para evitar o uso prolongado dos medicamentos antirretrovirais e suas consequências, dentre elas, destaca-se o uso de imunomoduladores como a interleucina 2 (IL-2), além da possibilidade de outras manipulações imunológicas antivirais mais específicas (12).

A utilização de vacinas terapêuticas ou o uso de imunomoduladores têm sido apontados como possíveis intervenções para aumentar a capacidade do organismo infectado em elaborar uma resposta específica contra o vírus. Alguns estudos preliminares sugerem que vacinas terapêuticas baseadas em DCs fornecem os melhores resultados no controle da infecção, embora seja necessário aprofundar os conhecimentos sobre os mecanismos de proteção induzidos por essas vacinas (13). Existem alguns ensaios clínicos já publicados em relação à imunoterapia baseada em DCs para o tratamento de indivíduos $\mathrm{HIV}^{+}$(14-20). A maioria desses ensaios detectou a indução de uma resposta imunológica por DCs pulsadas com diferentes antígenos de HIV. 
Neste contexto, Lu e colaboradores demonstraram que em um pequeno grupo de indivíduos infectados pelo HIV, a vacinação terapêutica utilizando DCs derivadas de monócitos pulsadas com vírus autólogo inativado, foi capaz de induzir in vivo uma resposta celular efetiva capaz de controlar por até um ano a replicação viral (21). Tais resultados demonstraram o potencial do uso desta vacina de DCs como estratégia terapêutica para o tratamento de pacientes $\mathrm{HIV}^{+}$.

Células apresentadoras de antígenos (APC, do inglês Antigen Presenting Cell), como as DCs, são responsáveis pela captura, processamento e apresentação de antígenos. Uma vez estimuladas, estas células expressam moléculas coestimuladoras, migram para órgãos linfoides secundários e produzem citocinas capazes de modular a resposta imune pelo estímulo de linfócitos $\mathrm{T}$ específicos (22).

DCs residem nos tecidos periféricos em um estado imaturo, monitorando o ambiente quanto à presença de patógenos e, a partir desse encontro, ocorre sua captura e processamento. Os produtos resultantes são integrados às moléculas do complexo principal de histocompatibilidade (MHC, do inglês Major Histocompatibility Complex) para posterior apresentação aos linfócitos T (23).

DCs imaturas, caracterizadas por baixos níveis de moléculas coestimuladoras, são particularmente eficazes na captura e processamento de antígenos, mas apresentam restrições para desencadear uma resposta imune produtiva mediada por linfócitos T (23). Além disso, são capazes de induzir tolerância devido à apresentação de antígenos sem sinais coestimuladores, necessários para uma completa ativação das células efetoras da resposta imunológica (24).

Um número crescente de estudos está relacionado à capacidade das DCs imaturas em induzir tolerância, tanto pela indução de anergia em linfócitos T quanto pela expansão de células $\mathrm{T}$ reguladoras (Tregs) após o processo de captura dos antígenos (25). Enquanto a maioria dos estudos clínicos sobre a utilização de vacinas de DCs tem como objetivo a estimulação do sistema imunológico, a descoberta do potencial das DCs imaturas em silenciar a resposta imune sugere um papel importante na aplicação dessas células para o tratamento de transplantes, alergias e doenças inflamatórias crônicas (23).

Após lesão tecidual, inflamação ou invasão por patógenos, DCs recebem sinais de ativação adicionais que induzem alterações fenotípicas e funcionais resultando no processo de maturação $(22,26)$. DCs maduras expressam altos níveis de complexos estáveis MHCpeptídeo na superfície celular, moléculas coestimuladoras e de adesão e baixos níveis de moléculas associadas à captura de antígenos (22). Estas células são eficazes na apresentação 
de antígenos e estímulo de células $\mathrm{T}$ naive localizadas em áreas específicas dos órgãos linfóides secundários, ou seja, estimulam uma resposta imunológica mediada por linfócitos T (27). A relação entre o estado de maturidade celular e a ação das DCs ainda não está bem definida e os mecanismos moleculares pelos quais essas células devem funcionar permanecem obscuros.

A utilização de vacinas de DCs pulsadas com antígenos virais em pacientes infectados pelo HIV visa o estímulo de resposta imune efetiva contra o vírus. A descoberta de que DCs mieloides podem ser geradas a partir de monócitos do sangue periférico ou de precursores $\mathrm{CD} 4^{+}$permitiu o desenvolvimento de estudos baseados na utilização dessas células geradas in vitro em protocolos clínicos de imunoterapia [3].

A cultura de monócitos na presença de IL-4 e fator de crescimento de colônia de granulócitos e macrófagos (GM-CSF, do inglês Granulocyte Macrophage Colony Stimulating Factor) origina DCs imaturas capazes de capturar e processar antígenos. A ativação das DCs, realizada através da adição de fatores indutores de maturação, promove profundas mudanças nas células, como redução na capacidade de capturar antígenos, aumento na expressão de moléculas coestimuladoras e capacidade de estimular linfócitos T. Por sua vez, uma gama de estímulos para maturação tem sido utilizada, como por exemplo, citocinas pró-inflamatórias, LPS (lipopolissacarídeos), CD40L, agonistas de receptores do tipo Toll (TLR, do inglês Toll like receptors), entre outros. Alternativamente, tem sido demonstrada a obtenção de DCs através da cultura de monócitos ou células progenitoras $\mathrm{CD}^{+} 4^{+}$na presença de interferon- $\alpha$ (IFN- $\alpha$ ) e GM-CSF, sendo denominadas IFN-DCs (28).

DCs são heterogêneas tanto fenotipicamente como funcionalmente (25). Além disso, uma mesma subpopulação de DCs pode ser responsável tanto pelas funções imunogênicas quanto pelas tolerogênicas, dependendo do nível de ativação, expressão de moléculas coestimuladoras e da quantidade de DCs que migram para os órgãos linfoides secundários, além de outros fatores (29). As propriedades que caracterizam a função estimuladora ou reguladora, incluindo a capacidade de indução de tolerância das DCs ainda não estão claramente identificadas. Neste contexto, um dos mecanismos atualmente propostos para diferenciar os perfis imunológicos adotados pelas DCs está relacionado com a expressão de enzimas envolvidas no processo de regulação da resposta imune como, por exemplo, a enzima indoleamina 2,3-dioxigenase (IDO).

IDO, uma enzima envolvida no catabolismo do triptofano, é expressa em determinadas células e tecidos, particularmente em células apresentadoras de antígenos, em órgãos linfoides e na placenta (30). Alguns estudos apoiam a ideia de que, além de atuar na defesa contra 
patógenos, essa enzima participa na regulação da resposta de células $\mathrm{T}$, incluindo clones autorreativos (31).

IDO catalisa o primeiro passo de degradação do triptofano na via da quinurenina e desempenha um papel central na conversão desse aminoácido em $\mathrm{N}$-formil-quinurenina. A via da quinurenina é a principal via para o metabolismo do triptofano e, sob circunstâncias normais, o catabolismo da proteína é balanceado por sua síntese, garantindo níveis constantes de triptofano no organismo (30). Aproximadamente $99 \%$ de todo triptofano consumido pela dieta e transformado bioquimicamente em outros compostos é metabolizado pela via da quinurenina (32). Embora a IDO tenha sido primeiramente descrita no intestino de coelhos em 1967 (33) e os mecanismos envolvendo resistência antimicrobiana sejam conhecidos há anos, apenas recentemente o significado biológico da indução dessa enzima vem sendo examinado em um contexto mais amplo (34).

Quando agentes infecciosos invadem os tecidos, leucócitos se acumulam no local da infecção e liberam interferons (IFN), principalmente IFN- $\gamma$ no tecido inflamado. O IFN- $\gamma$ age em receptores específicos e induz a expressão de IDO, de modo autócrino ou parácrino. $\mathrm{O}$ triptofano é degradado pela enzima IDO, o que inibe o crescimento de vírus, bactérias e parasitas, uma vez que o triptofano é um importante aminoácido essencial para o crescimento desses e de outros patógenos (35). Por outro lado, ocorre também uma supressão da resposta de células T, uma vez que os metabólitos derivados da degradação do triptofano exercem uma ação citotóxica sobre linfócitos $\mathrm{T}$ e inibem sua proliferação (36). Esse mecanismo afeta principalmente linfócitos $\mathrm{T}$ ativados e é potencializado gradualmente pelo tempo de exposição aos agentes tóxicos (37).

Em mamíferos, o estudo da enzima IDO teve início a partir da análise do processo imunossupressivo que previne a rejeição fetal no útero materno. O trabalho pioneiro de Mellor e Munn revelou o papel das células capazes de expressar IDO na regulação da imunidade celular materna durante a gravidez (38). O bloqueio do catabolismo do triptofano durante o período gestacional murino induz as células $\mathrm{T}$ maternas a promover uma rejeição ao aloenxerto fetal (39). Desse modo, fortes evidências sugerem que células placentárias capazes de sintetizar IDO protegem as células fetais contra o ataque dos linfócitos T maternos.

Furset e colaboradores demonstraram que a ativação de receptores toll-like, principalmente TLR 7 e 8, com ligantes específicos pode induzir a expressão de IDO em monócitos humanos, mas não em células dendríticas derivadas de monócitos (MoDCs, do inglês Monocyte Derived Dendritic Cell). Além disso, em contraste aos ligantes toll-like, o tratamento dessas mesmas MoDCs com IFN- $\gamma$ foi capaz de induzir a expressão da enzima 
(40). Em pacientes com carcinoma pulmonar, foi evidenciado que, em monócitos, os níveis de expressão da enzima IDO foram significativamente menores após tratamento quimioterápico (41). Esses dados sugerem alterações na expressão da enzima de acordo com o tipo celular ou estado de maturação estudado.

A supressão da resposta imune mediada por IDO adquire uma especial relevância em pacientes infectados pelo HIV. Nestes indivíduos, o quadro clínico de imunodeficiência é um marcador utilizado para acompanhamento da progressão da infecção. Em paralelo, a ativação de inúmeras células tem sido observada, incluindo linfócitos $\mathrm{B}$, linfócitos $\mathrm{T}$ e macrófagos. A produção de citocinas pró-inflamatórias como o fator de necrose tumoral (TNF- $\alpha$, do inglês Tumor Necrosis Factor) e IFN- $\gamma$ são cruciais na patogênese da doença (42). Desse modo, sugere-se que durante a infecção pelo HIV, o estado de imunodeficiência apareça juntamente com uma ativação exacerbada do sistema imunológico (43-45).

Indivíduos infectados pelo HIV, com progressão para o quadro clínico da AIDS, apresentam um aumento significativo de níveis plasmáticos de lipopolissacarídeos (LPS), um indicador para a ocorrência de translocação microbiana (passagem de produtos microbianos do lúmen intestinal para a corrente sanguínea sem bacteremia evidente, após danos na mucosa no trato gastrointestinal) (46). Além disso, também foi evidenciada estimulação crônica in vivo de monócitos por LPS, associação entre o aumento dos níveis plasmáticos de LPS e a ativação da imunidade inata e adaptativa, entretanto, após tratamento antirretroviral, observou-se diminuição dos níveis plasmáticos de LPS e reconstituição da população de linfócitos $\mathrm{T} \mathrm{CD}^{+}$(46). Esses dados sugerem que o aumento da translocação de produtos microbianos gastrointestinais contribui diretamente para uma ativação imune sistêmica na fase crônica da infecção pelo HIV e pode determinar a taxa de progressão da doença (46).

O HIV é capaz de induzir a síntese de IDO e, consequentemente, desencadear o metabolismo do triptofano em macrófagos humanos, um processo aparentemente mediado pela produção de IFN- $\gamma$ (47). Estudos indicam que IDO pode suprimir a resposta aos antígenos virais. Esta hipótese foi sugerida por Fuchs e colaboradores que constataram que pacientes infectados pelo HIV possuem redução crônica dos níveis plasmáticos de triptofano e aumento dos níveis de quinureninas, característicos de uma ampla ativação de IDO (48). Em 2013, um estudo revelou que a proteína Tat do HIV-1 é capaz de induzir a expressão de IDO em células dendríticas derivadas de monócitos de uma maneira independente de IFN- $\gamma$. Considerando-se o fato dessa mesma proteína viral também ser capaz de induzir a produção dessa citocina, tal correlação poderia influenciar os mecanismos de indução da enzima (figura 3) (49). 
Figura 3 - Resumo esquemático das funções da enzima indoleamina 2,3-dioxigenase (IDO) durante a infecção pelo HIV.

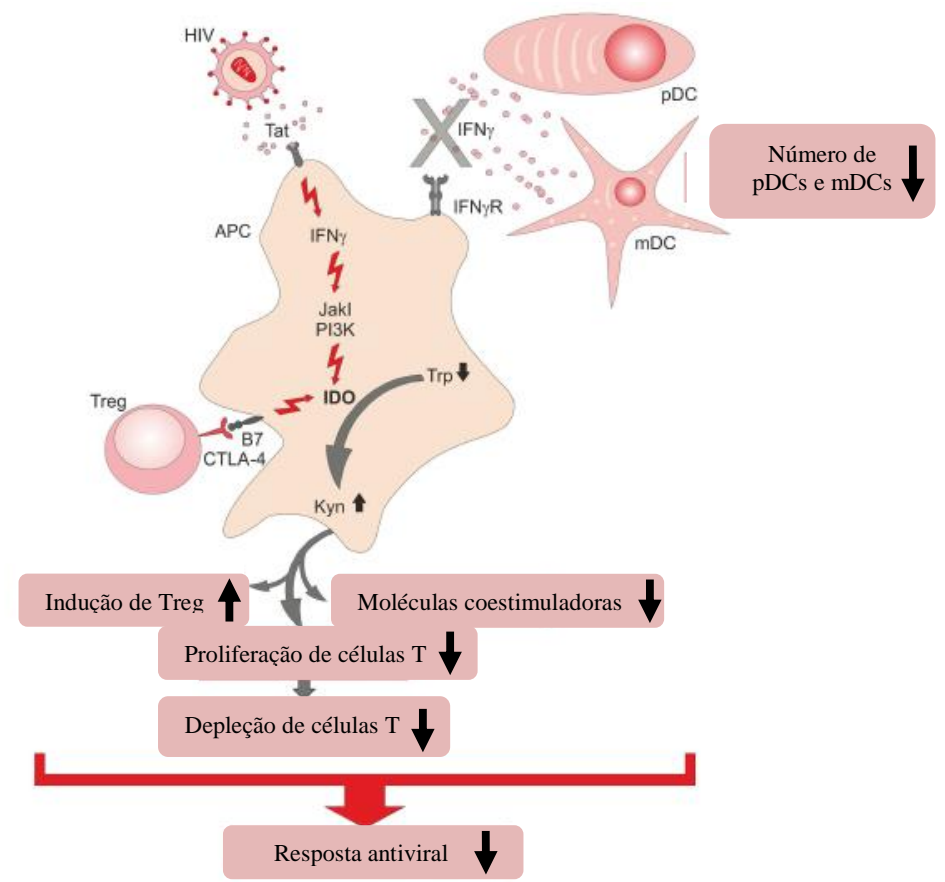

A indução direta de IDO em células apresentadoras de antígenos (APCs) pela proteína viral Tat é estabelecida por uma cascata de sinalização intracelular incluindo quinases (Jakl e PI3K) ou a interação de moléculas CTLA4 na superfície de linfócitos T reguladores (Tregs) com correceptores B7 na superfície das APCs, gerando a conversão de triptofano (Trp) em quinureninas (Kyn). A diminuição da resposta imune antiviral na fase crônica da infecção pelo HIV é causada por um bloqueio da resposta T celular, queda da secreção de IFN- $\gamma$ e indução de função imunossupressora de APCs capazes de expressar IDO. pDC (células dendríticas plasmocitóides); mDC (células dendríticas mielóides) Adaptado de Susanne V. Schmidt e Joachim Schultze, 2014).

Um dado interessante revela que a degradação do triptofano está aumentada na infecção pelo HIV e pode ser parcialmente revertida após tratamento antirretroviral, sugerindo que a ativação de linfócitos $\mathrm{T}$ e a produção de IFN- $\gamma$, mediadas pela proliferação do vírus, representam os principais estímulos para a indução de expressão de IDO e a hiperativação da enzima pode ser o ponto chave entre a ativação do sistema imune e a diminuição da resposta das células $\mathrm{T}(50,51)$.

Os mecanismos envolvendo a patogênese do HIV, expressão de IDO e regulação da resposta imunológica são bastante complexos e requerem análise detalhada para o estabelecimento de correlações adequadas. Nosso grupo de pesquisa vem desenvolvendo um trabalho sobre a utilização de vacina de células dendríticas derivadas de monócitos para o tratamento de pacientes $\mathrm{HIV}^{+}$, analisando os mecanismos imunes relacionados à proteção anti-HIV estimulada pelas DCs, buscando aumentar a eficácia das metodologias atualmente propostas. Além disso, as alterações na expressão da enzima IDO decorrentes do processo de 
obtenção das DCs derivadas de monócitos ainda não foram avaliadas em pacientes infectados pelo HIV.

A imunoterapia baseada em células dendríticas constitui uma estratégia promissora para o tratamento de indivíduos infectados pelo HIV. Devido à sua notória plasticidade, populações heterogêneas de MoDCs podem ser obtidas in vitro, dependendo das condições da cultura celular. Conseqüentemente pode ocorrer variação do perfil fenotípico e da eficácia da resposta imune estimulada por estas DCs.

No contexto de utilização de vacinas de DCs como alternativa terapêutica para o tratamento de pacientes infectados pelo HIV, a detecção da enzima IDO, desde os precursores (monócitos) até o produto final (células dendríticas), pode funcionar como marcador para caracterização do perfil das células geradas e associada com outros aspectos fenotípicos e funcionais, auxiliar no aperfeiçoamento das técnicas atualmente utilizadas.

Trabalhos recentes mostram que indivíduos infectados pelo HIV apresentam uma ampla ativação da enzima IDO e que isto pode estar relacionado à ativação do sistema imune e à redução da resposta de células $\mathrm{T}$ efetoras. Desse modo, tendo em vista a capacidade de DCs em expressar IDO, torna-se importante investigar a expressão desta enzima tanto nas DCs quanto em seus precursores, os monócitos.

Desse modo, o presente trabalho visa avaliar a expressão de IDO em monócitos e DCs derivadas de monócitos (MoDCs) de pacientes infectados pelo HIV e correlacionar esses achados com o perfil funcional das MoDCs geradas. Incluem-se nos objetivos específicos avaliar a expressão do RNAm da enzima IDO nos monócitos e nas MoDCs em diferentes estágios de maturação; avaliar a capacidade das MoDCs em apresentar antígenos de HIV a linfócitos autólogos, induzir diferenciação de células citotóxicas e atividade polifuncional por produção de IFN- $\gamma$, IL-2, TNF- $\alpha$ e MIP-1 $\beta$, além de correlacionar esses resultados com os níveis de expressão de IDO. 


\section{MÉTODOS}

\subsection{Casuística}

Os ensaios foram realizados com amostras de 5 doadores sadios e de 10 pacientes cronicamente infectados pelo HIV. Os critérios de inclusão foram: indivíduos com idade $\geq 18$ anos, ausência de terapia antirretroviral e contagem de células CD4 $\geq 500$ células $/ \mathrm{mm}^{3}$. Os critérios de exclusão foram: uso de terapia antirretroviral, corticoides, quimioterapia, gravidez ou qualquer outra condição com potencial para induzir imunodisfunção.

Todos os sujeitos envolvidos neste estudo participaram voluntariamente após assinatura de termo de consentimento livre e esclarecido, de acordo com a resolução No. 196/96 do Ministério da Saúde, sobre pesquisa envolvendo seres humanos.

Este projeto tem a aprovação da Comissão de Ética para Análise de Projetos de Pesquisa (CAPPesq) HCFMUSP - de acordo com parecer no. 202.010 de 20 de fevereiro de 2013 e da Comissão de Ética em Pesquisas em Seres Humanos do ICB/USP - de acordo com parecer no. 1140/CEP de 01 de outubro de 2013.

Tabela 1 - Caracterização dos indivíduos $\mathrm{HIV}^{+}$participantes do estudo com relação ao gênero, idade, carga viral plasmática e contagem de células TCD4 ${ }^{+}$.

\begin{tabular}{ccccc}
\hline Indivíduos & Sexo & Idade & $\begin{array}{c}\text { Carga viral } \\
(\text { cópias/mL) }\end{array}$ & $\begin{array}{c}\text { CD4 } \\
\text { (células/mm } \mathbf{m}^{\mathbf{3}} \text { ) }\end{array}$ \\
\hline P1 & M & 31 & $<40$ & 905 \\
P2 & M & 51 & 5870 & 511 \\
P3 & F & 28 & 1472 & 1503 \\
P4 & M & 37 & $<40$ & 754 \\
P5 & M & 52 & 1456 & 638 \\
P6 & M & 45 & 1890 & 825 \\
P7 & F & 38 & 3456 & 678 \\
P8 & M & 42 & 872 & 765 \\
P9 & F & 23 & 943 & 568 \\
\hline P10 & M & 29 & 324 & 678 \\
\hline Média & - & 37,6 & $\mathbf{1 6 3 6 , 3}$ & $\mathbf{7 8 2 , 5}$ \\
\hline
\end{tabular}


Tabela 2 - Caracterização dos indivíduos sadios participantes do estudo com relação ao gênero e idade.

\begin{tabular}{ccc}
\hline Indivíduos & Sexo & Idade \\
\hline C1 & M & 57 \\
C2 & F & 28 \\
C3 & F & 26 \\
C4 & M & 45 \\
C5 & M & 38 \\
Média & - & $\mathbf{3 8 , 8}$ \\
\hline
\end{tabular}

\subsection{Produção viral}

Para preparação de antígeno viral, o HIV, isolado de indivíduos cronicamente infectados, foi cultivado em células mononucleares de sangue periférico (PBMC, do inglês Peripheral Blood Mononuclear Cells) de doadores sadios previamente ativadas com fitohemaglutinina (PHA, do inglês Phytohemagglutinin) e IL-2. Posteriormente, o sobrenadante de cultura contendo o vírus foi concentrado e incubado com Aldrithiol-2 (AT-2) para inativação. Este tratamento induz modificações covalentes em proteínas virais do nucleocapsídeo e preserva a funcionalidade das glicoproteínas do envelope viral, mantendo a capacidade de integração do vírus, mas bloqueando o processo de replicação. O AT-2 residual foi removido e o vírus purificado através de ultracentrifugação em gradiente de sacarose (52).

\subsection{Obtenção de células mononucleares de sangue periférico (PBMCs)}

Foram coletados, através de punção venosa, cerca de $70 \mathrm{~mL}$ de sangue periférico em tubo heparinizado. O sangue foi diluído na proporção de 1:2 em salina e em seguida transferido cuidadosamente sobre o gradiente de densidade Ficoll-Paque ${ }^{\mathrm{TM}}$ Plus densidade 1076 (GE Healthcare, São Paulo, SP, Brasil) na proporção de 3 partes de sangue diluído para 1 parte de Ficoll, em tubo cônico de $50 \mathrm{~mL}$. Os tubos foram então centrifugados por 20 minutos a 2200 rpm, a nuvem de células mononucleares foi coletada em tubo cônico de $15 \mathrm{~mL}$, o volume foi completado com salina e o material passou por 2 ciclos de lavagem a $1500 \mathrm{rpm}$ por 10 minutos para retirada de resíduos de Ficoll. O pellet resultante de PBMCs foi ressuspendido 
em meio de cultura RPMI sem soro fetal e as células foram quantificadas por meio de coloração pelo Azul de Trypan (0,4\%, Sigma®, St. Louis, Missouri, EUA) em Câmara de Neubauer.

\subsection{Separação de monócitos por aderência}

A concentração de PBMCs foi ajustada para $5 \times 10^{6}$ células $/ \mathrm{mL}$ e a suspensão celular foi distribuída em placa de cultura de 12 poços (Jet-Biofil@, Seongbuk-gu, Seoul, Korea) com 1,0 $\mathrm{mL}$ da suspensão por poço. As PBMCs foram então incubadas em estufa com $5 \%$ de $\mathrm{CO}_{2}$ a 37 ${ }^{\circ} \mathrm{C}$ por 2 horas. Após esse período, as células não aderentes (predominantemente linfócitos e células NK) foram removidas e congeladas, as células aderentes remanescentes na placa (predominantemente monócitos) foram cultivadas em 1,0 mL de meio AIM-V (GIBCO®, Invitrogen, Waltham, MA, USA) ou removidas da placa para utilização em ensaios posteriores.

\subsection{Diferenciação de células dendríticas derivadas de monócitos (MoDCs)}

Para induzir a diferenciação em células dendríticas, foram acrescentados $50 \eta \mathrm{g} / \mathrm{mL}$ de IL4 e $50 \eta \mathrm{g} / \mathrm{mL}$ de GM-CSF à cultura de monócitos previamente separados por aderência. Em seguida, a placa foi incubada em estufa com $5 \% \mathrm{CO}_{2}$ a $37^{\circ} \mathrm{C}$. No quinto dia de cultivo, as MoDCs diferenciadas, ainda no estágio imaturo, foram pulsadas ou não com HIV quimicamente inativado por 2 horas e ativadas com as citocinas pró-inflamatórias TNF- $\alpha$ (50 $\eta \mathrm{g} / \mathrm{mL}), \mathrm{IL}-1 \beta(10 \eta \mathrm{g} / \mathrm{mL})$ e IL-6 (100 $\eta \mathrm{g} / \mathrm{mL})$ para indução de maturação celular. Apesar do importante papel do IFN- $\gamma$ na indução da enzima de interesse descrita nesse trabalho, optamos por utilizar o coquetel de citocinas pró-inflamatórias descrito anteriormente para indução de maturação, a fim de estabelecer correlações entre a expressão e atividade da enzima IDO no protocolo padrão de geração de DCs como produto vacinal em desenvolvimento pelo nosso grupo de estudo. Também foi acrescentado um reforço de IL-4 e GM-CSF na mesma dose utilizada para induzir a diferenciação. A partir de agora, os dois perfis de DCs que receberam o coquetel de ativação, DCs maduras e pulsadas, também serão denominadas de DCs ativadas. Para uma melhor análise da capacidade do HIV quimicamente inativado em induzir alterações fenotípicas e funcionais nas MoDCs, uma porção dessas células geradas foi tratada somente com o vírus inativado, sem adição do coquetel de citocinas pró-inflamatórias. Além disso, para aprofundar o estudo sobre a enzima de interesse, uma porção das MoDCs ativadas foi tratada com $100 \mu \mathrm{M}$ de 1-metil-triptofano, bloqueador competitivo de IDO, 24 horas antes 
da indução de maturação. No sétimo dia de cultivo, ou seja, 48 horas após a ativação, as MoDCs, denominadas a partir de agora como DCs, foram separadas e utilizadas para os ensaios fenotípicos e funcionais.

\subsection{Marcação extracelular de monócitos e DCs para citometria de fluxo}

Monócitos e DCs obtidas em cultura foram lavados com PBS e o pellet foi ressuspendido em tampão de marcação com tampão fosfato salino (PBS, do inglês Phosphate Buffer Saline) contendo 0,2\% de albumina sérica bovina (BSA, do inglês Bovine Serum Albumin). Em seguida, a concentração celular foi ajustada para $2 \times 10^{6}$ células $/ \mathrm{mL}$ e $100 \mu \mathrm{L}$ da solução foram adicionados em cada tubo de marcação e, após adição dos anticorpos monoclonais específicos, as células foram incubadas por 20 minutos, a $4^{\circ} \mathrm{C}$ e protegidas da luz. Após lavagem com tampão de marcação, as células foram ressuspendidas em $400 \mu \mathrm{L}$ de solução isotônica. A aquisição das células foi realizada em citômetro de fluxo BD LSR Fortessa ${ }^{\mathrm{TM}}$ (BD Biosciences, Franklin Lakes, Nova Jérsia, EUA) com cerca de 50.000 eventos totais e os dados foram analisados utilizando os softwares BD FACSDiva ${ }^{\mathrm{TM}}$ (BD Biosciences) $e$ FlowJo ${ }^{\mathrm{TM}}$ (Ashland, Oregon, USA). Os anticorpos monoclonais utilizados para fenotipagem dos monócitos foram: CD11c Alexa Fluor 700, CD14 Qdot605, HLADR V500 e CD86 PeCy7 (BD Biosciences). Os anticorpos monoclonais utilizados para fenotipagem das DCs foram: CD11c Alexa Fluor 700, CD14 Qdot605, HLADR V500, CD1a FITC, CD80 PeCy5, CD86 PeCy7, CD40 APCH7 e CD83 APC (BD Biosciences).

\subsection{Marcação intracelular de monócitos e DCs para citometria de fluxo}

Para avaliar a expressão da enzima IDO, os monócitos e as DCs foram marcados com anticorpo intracelular específico anti- human IDO PE (R\&D Systems Minneapolis, MN, USA). Para a realização dessa técnica, foi utilizado kit Cytofix/Cytoperm (BD Biosciences). As células já marcadas extracelularmente e armazenadas a $4{ }^{\circ} \mathrm{C}$ como descrito anteriormente, foram lavadas em tampão de marcação, ressuspendidas em $300 \mu \mathrm{L}$ de solução de fixação Cytofix/Cytoperm e incubadas a $4^{\circ} \mathrm{C}$ por 20 minutos no escuro. Depois de fixadas, as células foram lavadas duas vezes com solução de permeabilização e lavagem Perm/Wash e ressuspendidas em $25 \mu \mathrm{L}$ da mesma solução. Em seguida, $5 \mu \mathrm{L}$ do anticorpo anti-human IDO foram acrescentados e as células permaneceram incubadas por 30 minutos, a $4^{\circ} \mathrm{C}$ e protegidas de luz. Posteriormente, as células foram lavadas duas vezes com o reagente Perm/Wash e 
ressuspendidas em $400 \mu \mathrm{L}$ de solução isotônica. A aquisição das células foi realizada em citômetro BD LSR Fortessa ${ }^{\mathrm{TM}}$ (BD Biosciences) com cerca de 50.000 eventos totais e os dados analisados utilizando os software BD FACSDiva ${ }^{\mathrm{TM}}$ (BD Biosciences) e FlowJo ${ }^{\mathrm{TM}}$.

\subsection{Quantificação de RNAm da enzima IDO - PCR em tempo real}

O RNA (Ácido Ribonucléico, do inglês Ribonucleic Acid) total dos monócitos e das DCs geradas foi extraído com kit RNAqueous-Micro (Ambion, Applied Biosystems Waltham, MA, USA) seguindo as orientações fornecidas pelo fabricante. Para obtenção do DNA complementar (cDNA, do inglês complementary Deoxyribonucleic Acid) a partir do RNA total purificado, foi utilizada a metodologia do kit SuperScript ${ }^{T M}$ III Reverse Transcriptase (Invitrogen, Carlsbad, CA, EUA). Para a reação de amplificação em tempo real, foram utilizados para cada amostra de cDNA $(1 \mu \mathrm{L}) 10 \mu \mathrm{L}$ da solução Platinum SYBR Green qPCR SuperMix-UDG (Invitrogen), 0,4 $\mu \mathrm{L}$ de ROX Reference Dye, 7,3 $\mu \mathrm{L}$ de água destilada estéril e $200 \eta \mathrm{M}$ do primer (Invitrogen).

A síntese dos primers foi realizada pela Invitrogen. Sequência dos primers: IDO (sense 5'GGTCATGGAGATGTCCGTAA-3' e antisense 5'-ACC AATAGAGAGACCAAGAAGAA3') e $\beta$-actina (sense 5'-GCTGTCATCTCTTGTGG GCTGT-3' e antisense (5'AAACTCATGGGAGCTGCTGGTT-3').

A amplificação foi realizada em 45 ciclos de 15 segundos a $95^{\circ} \mathrm{C}$ e 30 segundos a $60^{\circ} \mathrm{C}$, em termociclador 7500 PCR Real Time System (Applied Biosystems). Os dados obtidos foram interpretados com o programa 7500 System software. Os resultados foram avaliados pelo threshold cycle $(c t)$ do gene de interesse normalizado com o ct do controle interno ( $\beta$ actina). A expressão quantitativa relativa dos genes foi calculada como $2^{-\Delta \Delta \mathrm{CT}}$ de acordo com Livak et al (53).

$\Delta \mathrm{CT}=\mathrm{CT}($ controle interno $)-\mathrm{CT}$ (enzima de interesse)

$\Delta \Delta \mathrm{CT}=\Delta \mathrm{CT}(\mathrm{DCs}$ maduras ou pulsadas $)-\Delta \mathrm{CT}$ (DCs imaturas) 


\subsection{Avaliação da resposta linfoproliferativa induzida por DCs}

O potencial das MoDCs em induzir a proliferação de linfócitos T autólogos foi avaliado através do monitoramento de carboxifluoresceina diacetato sucinimidil ester (CFSE) por citometria de fluxo, visto que o CFSE possui propriedades de excitação e emissão semelhantes ao fluorocromo FITC.

CFSE é um corante difundido passivamente nas células que, quando clivado por esterases intracelulares, passa a emitir fluorescência e perde a capacidade de se difundir através da membrana. Desse modo, o corante fica aprisionado no interior da célula onde permanece durante a divisão celular (54). Assim, através da redução da concentração intracelular de CFSE a cada geração de células filhas, é possível analisar a proliferação celular.

Para este ensaio, células não aderentes autólogas (predominantemente linfócitos) foram primeiramente marcadas com CFSE, seguindo as orientações do fabricante. Para tanto, $1 \times 10^{7}$ linfócitos foram incubados com $2 \mu \mathrm{M}$ de CFSE (concentração final) em meio RPMI 1640 aquecido, durante 15 minutos em banho-maria a $37^{\circ} \mathrm{C}$, sob agitação. A seguir, o excesso do corante não difundido para o interior das células foi retirado por meio de três lavagens $(600 \mathrm{~g}$ por 10 minutos a $15^{\circ} \mathrm{C}$ ) com meio RPMI $1640+10 \%$ de SFB.

Finalmente, $2 \times 10^{5}$ linfócitos marcados com CFSE foram cocultivados com $0,4 \times 10^{5}$ MoDCs nos diferentes estágios de maturação (proporção de 5 linfócitos: $1 \mathrm{MoDC}$ ), emplaca de 96 poços fundo em U, no volume final de $200 \mu \mathrm{L}$ de meio AIM-V com 10\% de SAB. A cultura foi mantida em estufa a $37^{\circ} \mathrm{C}$ e $5 \%$ de $\mathrm{CO} 2$ por até 96 horas.

O controle positivo $(\mathrm{C}+)$ foi constituído por linfócitos ativados durante as últimas 72 horas de cultura com $5 \mu \mathrm{g} / \mathrm{mL}$ de PHA e o controle negativo (basal) por linfócitos que não receberam estímulo.

Após o término dos tempos estudados (24 e 96 horas) foi realizada a marcação extracelular dos linfócitos utilizando os anticorpos CD3 PeCy5, CD8 APCH7 (BD Biosciences) e CD4 Qdot605 (Invitrogen) para posterior análise por citometria de fluxo.

\subsection{Avaliação da polifuncionalidade de linfócitos autólogos estimulados por DCs}

A capacidade das DCs em induzir uma resposta celular polifuncional in vitro foi avaliada por meio da detecção simultânea de IFN- $\gamma$, IL-2, TNF- $\alpha$ e MIP-1 $\beta$ em células TCD4 ${ }^{+}$e $\mathrm{TCD}^{+}$citotóxicas ou não. Para isso, células autólogas não aderentes (predominantemente linfócitos), conservadas por congelamento, foram descongeladas 24 horas antes do início do 
ensaio e cocultivadas com DCs imaturas, maduras e pulsadas com HIV quimicamente inativado. As células foram cultivadas na proporção de 1 DC (célula estimuladora) para 5 linfócitos autólogos (células respondedoras) em placa de 96 poços de fundo "U" em diferentes tempos (0, 24 e 96 horas após início do cocultivo), em meio de cultura AIM-V® (GIBCOß) suplementado com $10 \%$ de SAB (Sigma). Seis horas antes do término de cada tempo de cultura, foram acrescentados $20 \mu \mathrm{g} / \mathrm{mL}$ de Brefeldina A (BFA), um bloqueador do complexo de golgi, com o intuito de acumular proteínas no retículo endoplasmático da célula e impedir a secreção de citocinas pelos linfócitos. O controle positivo foi composto por culturas estimuladas por 6 horas com $1 \mu \mathrm{g} / \mathrm{mL}$ de SEB (enterotoxina B de estafilococos) que possui propriedades mitogênicas sobre os linfócitos T. Após cada um dos períodos de cocultivo determinados, os linfócitos foram marcados com anticorpos específicos conjugados a diferentes fluorocromos: CD3 PeCy5, CD8 APCH7, IL-2 FITC, MIP-1 $\beta$ Alexa Fluor 700, TNF- $\alpha$ PeCy7, IFN- $\gamma$ PE, CD107a APC (BD Biosciences), CD4 Qdot605 (Invitrogen) e analisados por citometria de fluxo.

\subsection{Marcação de linfócitos para ensaio de citometria de fluxo}

Após o término de cada período de cocultivo, os linfócitos foram lavados com PBS e o pellet foi ressuspendido em tampão de marcação (PBS contendo 0,2\% de BSA). Em seguida, a concentração celular foi ajustada para $2 \times 10^{6}$ células $/ \mathrm{mL}$ e $100 \mu \mathrm{L}$ da solução foi adicionada em cada tubo de marcação. Após adição dos anticorpos monoclonais específicos, as células foram incubadas por 20 minutos, a $4^{\circ} \mathrm{C}$ e protegidas da luz. Para a marcação intracelular dos linfócitos foi utilizado kit Cytofix/Cytoperm (BD Biosciences). Após lavagem com tampão de marcação, as células foram ressuspendidas em $300 \mu \mathrm{L}$ de solução de fixação Cytofix/Cytoperm e incubadas a $4^{\circ} \mathrm{C}$ por 20 minutos no escuro. Depois de fixadas, as células foram lavadas duas vezes com solução de permeabilização e lavagem Perm/Wash e ressuspendidas em $25 \mu \mathrm{L}$ da mesma solução. Em seguida foram acrescentados os anticorpos monoclonais específicos e as células permaneceram incubadas por 30 minutos, a $4^{\circ} \mathrm{C}$ e protegidas de luz. Posteriormente, as células foram lavadas duas vezes com o reagente Perm/Wash e ressuspendidas em $400 \mu \mathrm{L}$ de solução isotônica. A aquisição das células foi realizada em citômetro BD LSR Fortessa ${ }^{\mathrm{TM}}$ (BD Biosciences) com cerca de 150.000 eventos totais e os dados analisados utilizando os software BD FACSDiva ${ }^{\mathrm{TM}}$ (BD Biosciences) e FlowJo $^{\mathrm{TM}}$, Pestle e SPICE. 


\subsection{Congelamento de células}

Para congelamento, as células foram lavadas e ressuspendidas em SFB, seguido da adição por gotejamento de igual volume de solução de DMSO $20 \%$ em SFB. O material foi transferido para criotubos e acondicionado em container contendo álcool isopropílico. Tal dispositivo possibilita o congelamento gradual das células, uma vez que permite a diminuição controlada da temperatura (redução de $1{ }^{\circ} \mathrm{C}$ por minuto), resultando na obtenção de maiores índices de viabilidade celular após o descongelamento.

\subsection{Descongelamento de células}

Para descongelamento, o criotubo foi colocado em banho-maria a $37^{\circ} \mathrm{C}$ e em seguida a suspensão foi diluída em $10 \mathrm{~mL}$ de meio de cultura. Após 2 ciclos de lavagem em meio de cultura a viabilidade celular foi determinada por meio de contagem das células coradas pelo Azul de Trypan $(0,4 \%$, Sigma®) em Câmara de Neubauer.

\subsection{Análise de dados}

As análises dos dados obtidos foram realizadas com base no teste estatístico two-way ANOVA com Bonferroni pós-teste e teste não paramétrico Kruskal-Wallis, por meio de software específico (GraphPad Prism ${ }^{\circledR}$ 5.0, La Jolla, CA,USA). Os valores de p<0,05 foram considerados estatisticamente significantes.

Para a obtenção dos resultados de detecção simultânea de mediadores imunológicos produzidos por células T estimuladas por DCs em ensaio de cocultivo foi utilizada análise booleana dos dados com auxílio dos programas FlowJo ${ }^{\mathrm{TM}}$, Pestle e SPICE $(55,56)$. 


\section{RESULTADOS}

\subsection{Perfil morfológico de monócitos e de DCs}

Para análise do aspecto morfológico, os monócitos e a DCs geradas foram visualizadas por meio de microscopia óptica. A figura 4 representa as características morfológicas de monócitos, DCs imaturas, maduras e pulsadas diferenciadas a partir de amostras de paciente infectado pelo HIV, além do esquema de diferenciação dessas células. Para uma melhor análise das DCs geradas, consideramos como DCs imaturas aquelas que não receberam nenhum tipo de estímulo de ativação durante o período de cultura, DCs maduras aquelas ativadas com coquetel de citocinas pró-inflamatórias e DCs pulsadas aquelas que receberam pulso com HIV quimicamente inativado 2 horas antes da ativação com o coquetel de citocinas pró-inflamatórias.

Com base nas fotografias obtidas foi possível observar que os monócitos e as DCs imaturas apresentam-se mais arredondados e, após o processo de ativação com coquetel de citocinas pró-inflamatórias, tanto as DCs maduras quanto as pulsadas adquirem aspecto mais espraiado e fusiforme.

Figura 4 - Aspecto morfológico e esquema de diferenciação dos monócitos e das DCs de indivíduo infectado pelo HIV.

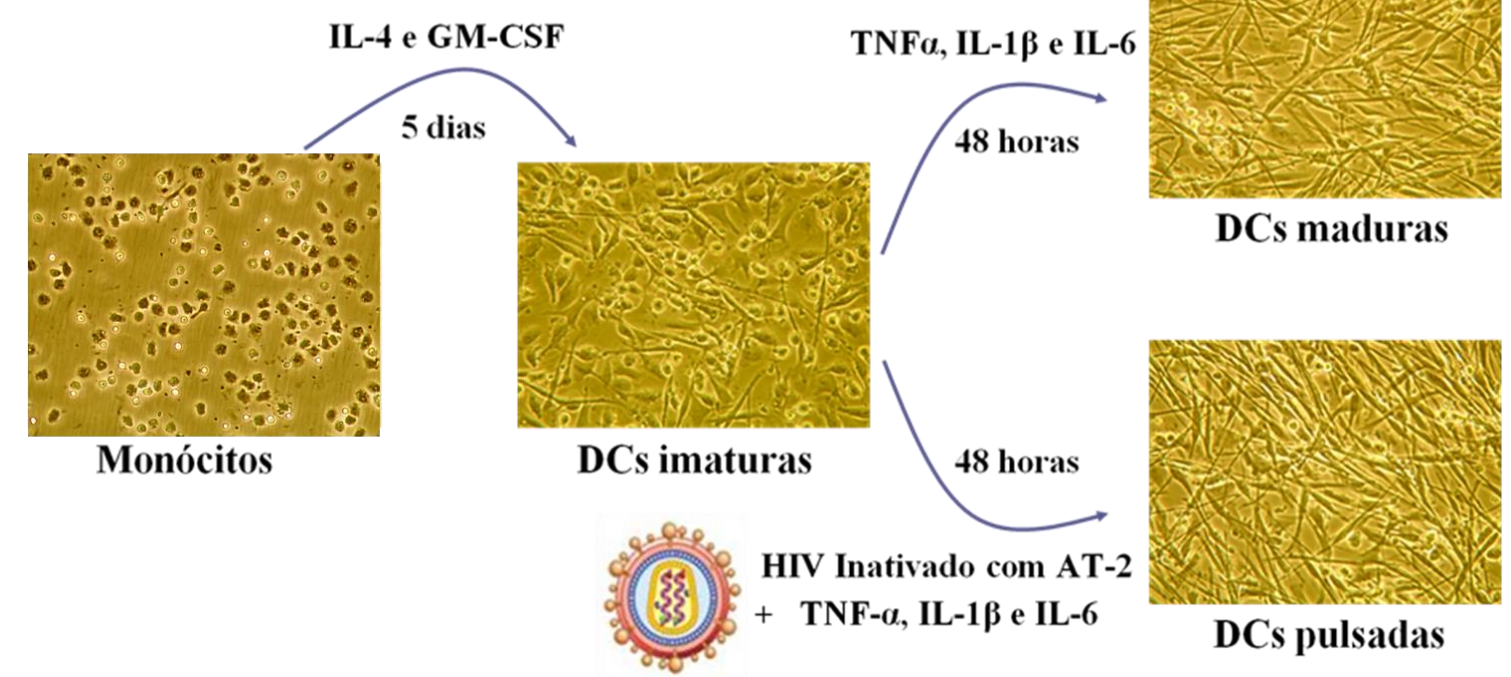

As células foram visualizadas por meio de microscopia óptica, no aumento 200x, em seu estágio basal (monócitos), imaturo e após ativação (maduras e pulsadas). 


\subsection{Perfil fenotípico de monócitos}

O perfil fenotípico dos monócitos foi analisado através de citometria de fluxo em relação à expressão de marcadores de superfície específicos envolvidos na caracterização dessa população: CD11c (marcador de células mielóides), CD14 (marcador de monócitos), HLADR (marcador associado com a capacidade de apresentação antigênica) e CD86 (marcador de coestimulação).

Primeiramente, a população de monócitos foi analisada com base no isolamento das células que passaram individualmente pelo laser do equipamento através do fluxo de amostras (singlets) e posteriormente com relação ao seu tamanho e complexidade interna dos grânulos (FSC x SSC). Em seguida, as células $\mathrm{CD} 11 \mathrm{c}^{+}$e $\mathrm{CD} 14^{+}$foram identificadas e selecionadas para análise da expressão dos demais marcadores (figura 5A).

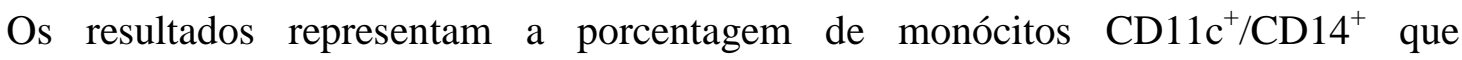
expressam HLADR e CD86, indicados como as médias e respectivos desvios padrão referentes à análise de 5 amostras provenientes de indivíduos sadios e de 10 amostras provenientes de indivíduos $\mathrm{HIV}^{+}$(figura 5B).

Além disso, a análise desses mesmos marcadores celulares também foi realizada com base na intensidade de fluorescência média (MFI, do inglês Mean Fluorescence Intensity) tanto no grupo de indivíduos sadios quanto no grupo de indivíduos $\mathrm{HIV}^{+}$(figura 5C).

Observa-se, como esperado, altos níveis de expressão de HLADR e CD86 nos monócitos dos indivíduos estudados, sendo essa expressão similar nos grupos de indivíduos sadios e $\mathrm{HIV}^{+}$. Apesar disso, quando analisamos a MFI do marcador de coestimulação CD86 nos indivíduos $\mathrm{HIV}^{+}$, observamos um aumento significativo em comparação ao grupo de indivíduos sadios.

Esses resultados revelam que, apesar do número de monócitos capazes de expressar a molécula CD86 ser semelhante entre os grupos estudados, a quantidade de moléculas CD86 por monócito analisado se mostrou significativamente maior no grupo de indivíduos $\mathrm{HIV}^{+}$, sugerindo um nível mais elevado de ativação dessa população celular. 
Figura 5 - Perfil fenotípico de monócitos.

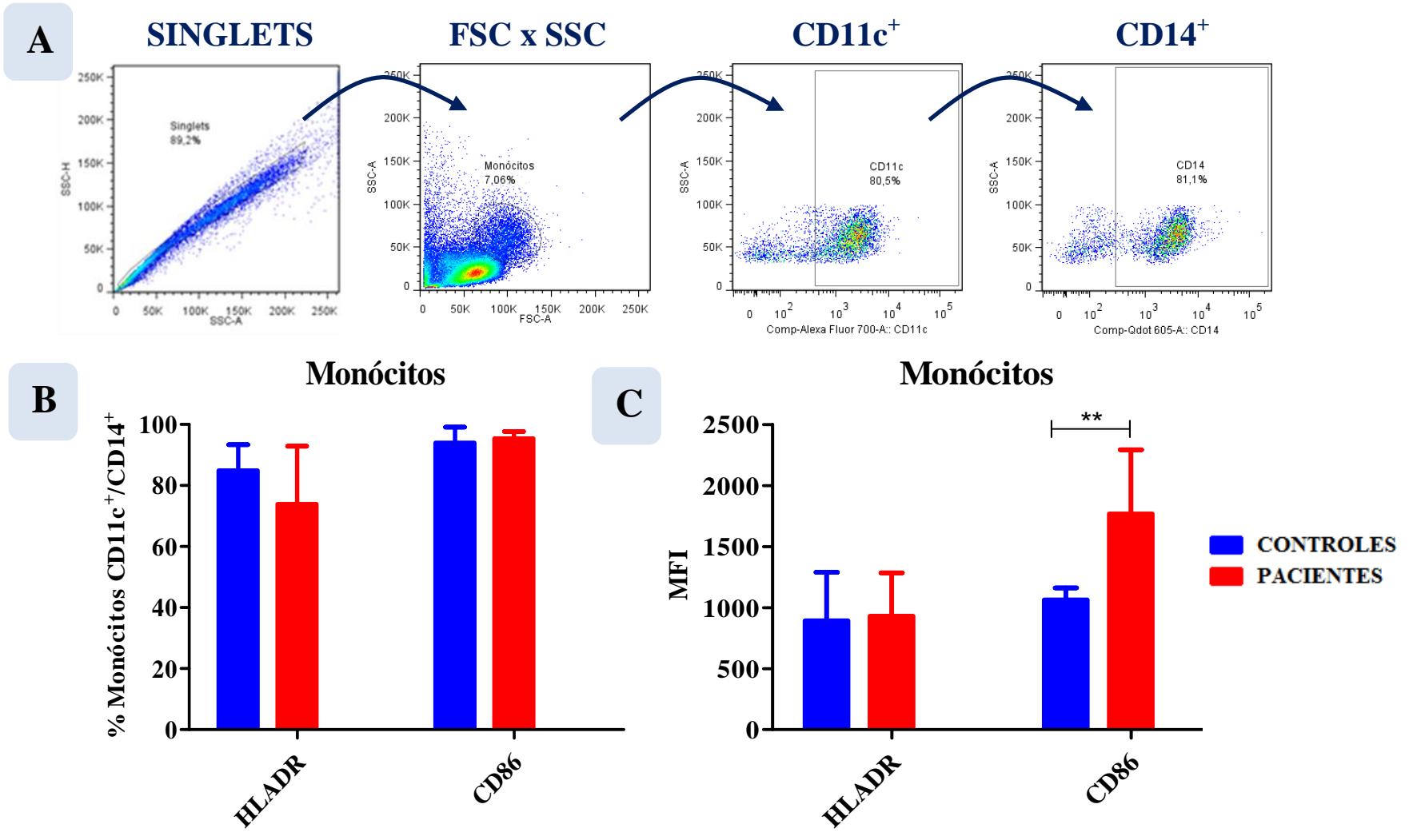

A análise da expressão de marcadores específicos foi realizada na população de monócitos $\mathrm{CD} 11 \mathrm{c}^{+} / \mathrm{CD} 14^{+}$, separados primeiramente de acordo com os singlets, tamanho e granulosidade (A). Monócitos obtidos de indivíduos sadios e indivíduos infectados pelo $\mathrm{HIV}^{+}$foram caracterizados com relação à expressão de HLADR e CD86. As barras representam as médias e respectivos desvios padrão referentes ao percentual celular (B) e MFI (C) dos resultados obtidos nos 5 experimentos realizados com indivíduos sadios (controles) e nos 10 experimentos realizados com indivíduos $\mathrm{HIV}^{+}$. (**) $\mathrm{P}<0,01$

\subsection{Perfil fenotípico de DCs}

O perfil fenotípico das DCs geradas foi analisado pela técnica de citometria de fluxo em relação à expressão de marcadores de superfície específicos envolvidos na caracterização da população de DCs (CD11c e CD1a), apresentação antigênica (HLADR), coestimulação (CD80, CD86 e CD40) e ativação celular (CD83).

Primeiramente, a população de DCs foi analisada em relação ao seu tamanho e complexidade interna dos grânulos (FSC x SSC). Em seguida, as células CD11c ${ }^{+}$e CD14 foram identificadas e selecionadas para análise da expressão dos demais marcadores (figura 6A). 
A diferenciação da população de monócitos em DCs é evidenciada pela alta expressão de moléculas do MHC classe II (HLADR), perda de expressão de CD14, marcador associado a monócitos, além de alta expressão de CD11c, de modo que esses dois últimos marcadores foram utilizados para seleção da população de interesse.

Os resultados demonstrados representam as médias, com respectivos desvios padrão, da análise da expressão dos marcadores citados nos 5 experimentos realizados com indivíduos sadios (figura 6B) e nos 10 experimentos realizados com indivíduos $\mathrm{HIV}^{+}$(figura 6C).

Figura 6 - Perfil fenotípico de DCs.

A

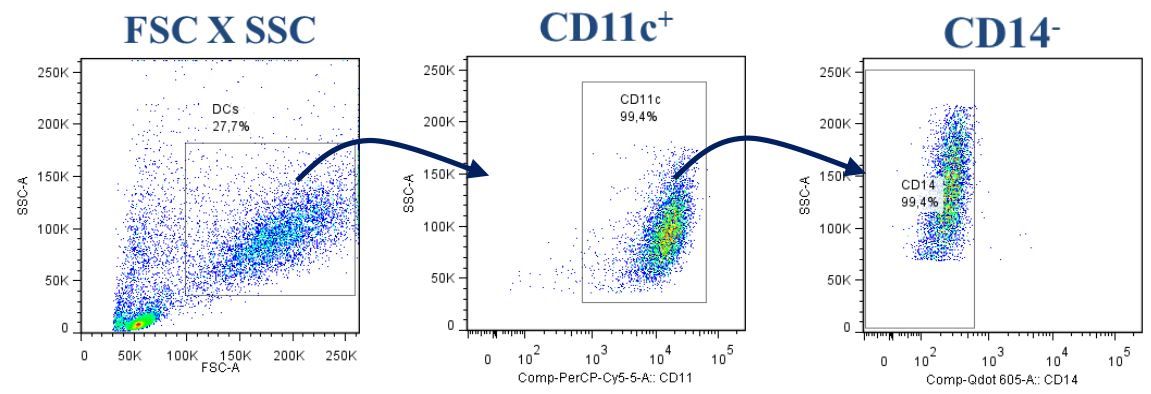

B

CONTROLES

C

PACIENTES

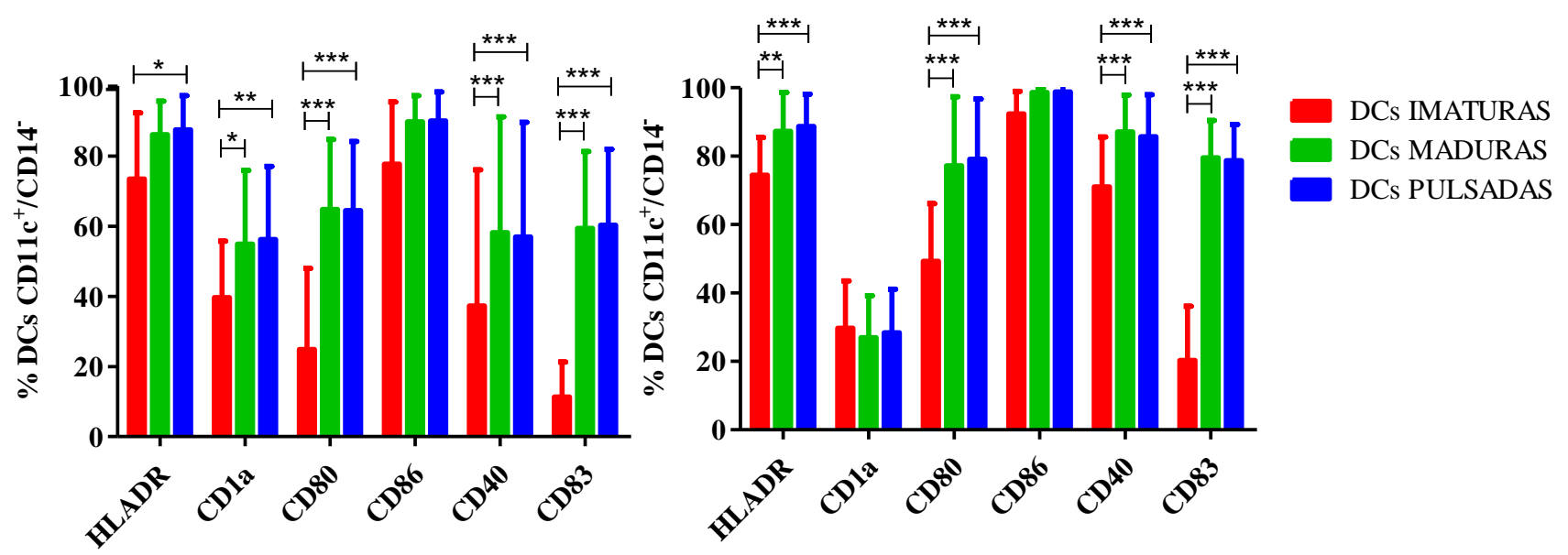

A análise da expressão de marcadores específicos foi realizada na população de DCs CD11c ${ }^{+} / C^{2} 14^{-}$, separadas primeiramente de acordo com tamanho e granulosidade (A). DCs imaturas, maduras e pulsadas, foram caracterizadas com relação à expressão de HLADR, CD1a, CD80, CD86, CD40 e CD83. As barras representam as médias e respectivos desvios padrão referentes aos resultados obtidos nos 3 experimentos realizados com indivíduos sadios (controles) e nos 4 experimentos realizados com indivíduos $\mathrm{HIV}^{+}$. (*) $^{*}<0,05$ (**) $^{*}<0,01$ $(* * *) \mathrm{p}<0,001$

Com relação à caracterização fenotípica da população considerada como DCs (CD11 $\left.\mathrm{c}^{+} / \mathrm{CD} 14^{-}\right)$, observa-se que o estímulo de DCs com citocinas pro-inflamatórias levou a um aumento significativo na expressão de HLADR, CD80, CD40 e CD83 tanto no grupo de 
indivíduos sadios quanto no grupo de indivíduos $\mathrm{HIV}^{+}$. Observou-se ainda um aumento significativo na expressão da molécula CD1a, quando comparamos as DCs imaturas com as ativadas, apenas no grupo de indivíduos sadios.

Para uma melhor compreensão das possíveis diferenças encontradas em determinados marcadores entre o grupo de indivíduos sadios e $\mathrm{HIV}^{+}$, comparamos a expressão de cada um dos marcadores de caracterização e ativação celular nos dois grupos estudados, tanto com base no percentual de células que expressam esses marcadores (figura 7), quanto na intensidade de fluorescência média determinada por cada marcador (figura 8).

A partir dos resultados obtidos não foi possível evidenciar diferença estatística significante entre pacientes e indivíduos sadios em relação aos marcadores CD80 e CD83, tanto em relação ao percentual de expressão (figuras 7C e 7F), quanto em relação à intensidade média de fluorescência emitida (figuras $8 \mathrm{C}$ e 8F).

As DCs ativadas do grupo de indivíduos infectados pelo HIV apresentaram níveis de expressão do marcador CD1a significativamente menores, nos dois modelos de análise realizados, quando comparadas as DCs ativadas do grupo de indivíduos sadios (figuras $7 \mathbf{B}$ e 8B).

Além disso, essa mesma população celular também apresentou níveis significativamente menores na intensidade de fluorescência media do marcador HLADR no grupo de indivíduos $\mathrm{HIV}^{+}$em relação ao grupo de indivíduos sadios (figura 8A).

Também foi possível observar um aumento significativo na expressão dos marcadores de coestimulação CD86 e CD40, em relação ao percentual celular, nas DCs imaturas dos indivíduos $\mathrm{HIV}^{+}$, quando comparados aos sadios (figuras 7D e 7E). 
Figura 7: Perfil fenotípico de DCs com base no percentual de expressão de marcadores de caracterização e ativação celular.

A

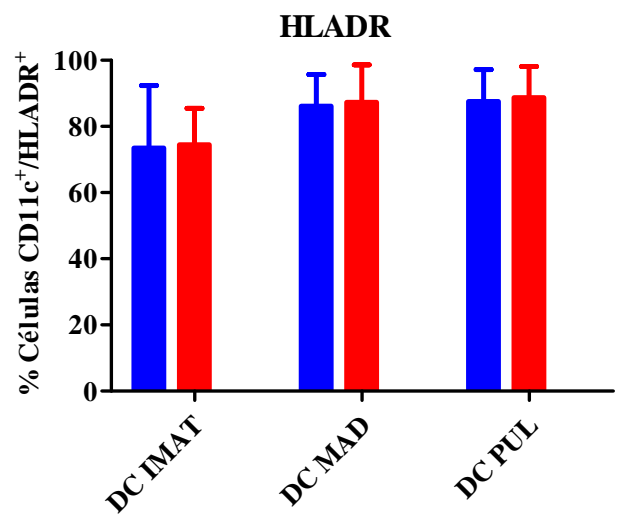

C

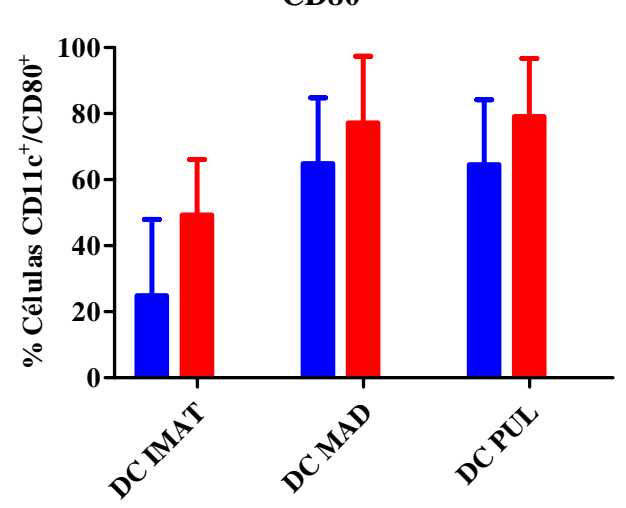

$\mathbf{E}$

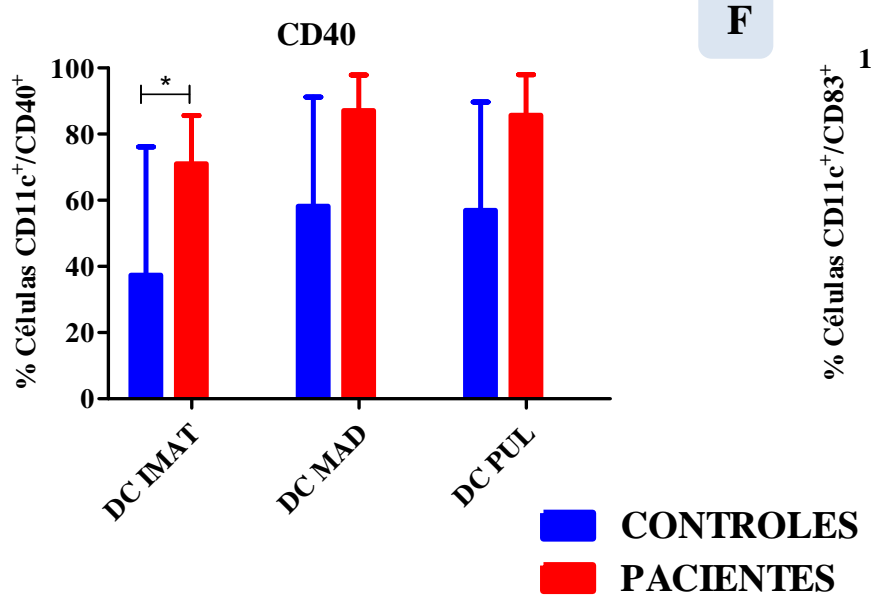

B

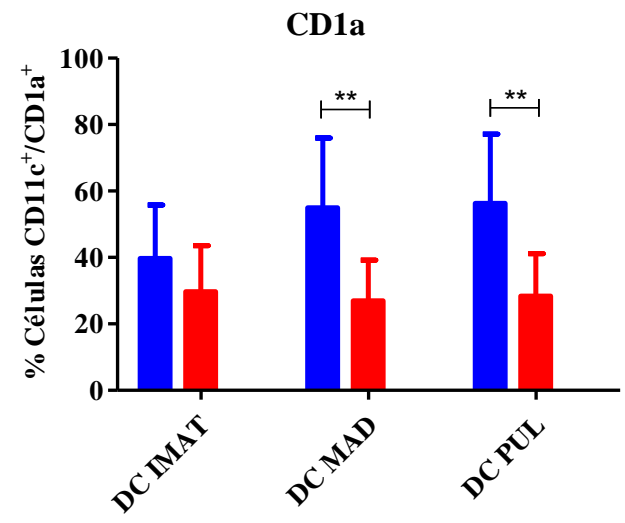

D

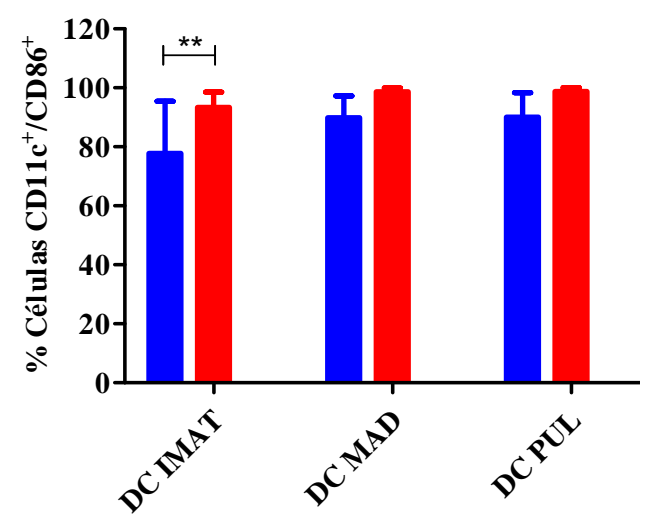

CD83

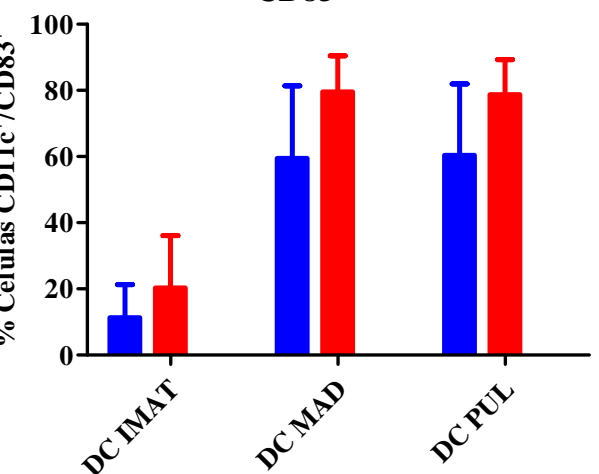

A análise da expressão de marcadores específicos foi realizada na população de DCs CD11c ${ }^{+} / \mathrm{CD}^{-} 4^{-}$separadas primeiramente de acordo com o tamanho e a granulosidade celular. As barras representam as médias e respectivos desvios padrão referentes aos resultados obtidos nos 5 experimentos realizados com indivíduos sadios (controles) e nos 10 experimentos realizados com indivíduos $\mathrm{HIV}^{+}$em relação aos marcadores HLADR (A), CD1a (B), CD80 (C), CD86 (D), CD40 (E) e CD83 (F). 
Figura 8 - Perfil fenotípico de DCs com base na intensidade de fluorescência média de marcadores de caracterização e ativação celular.

A

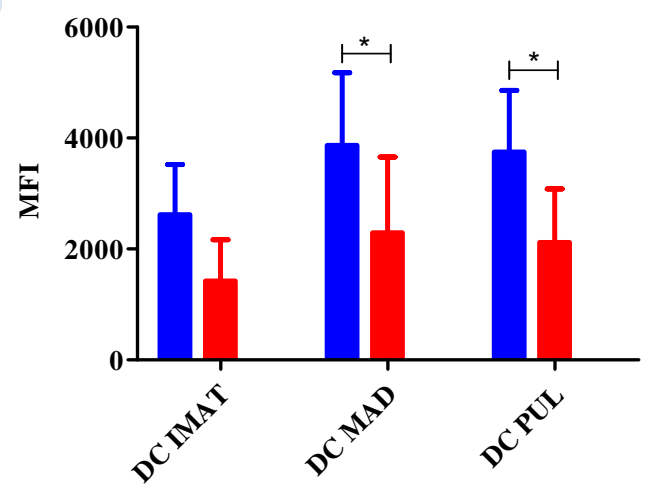

C

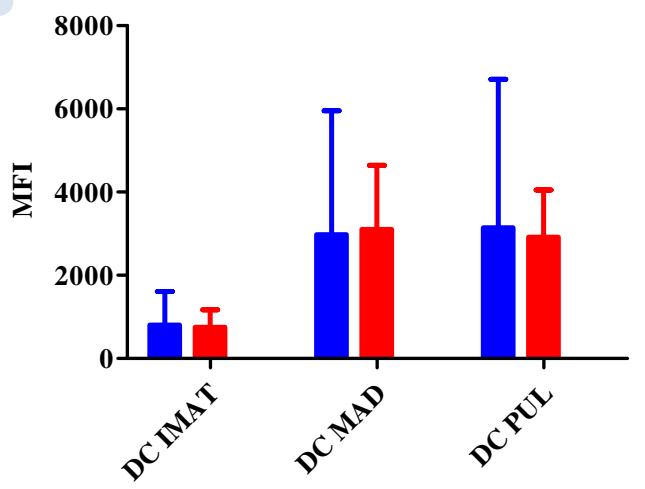

$\mathbf{E}$

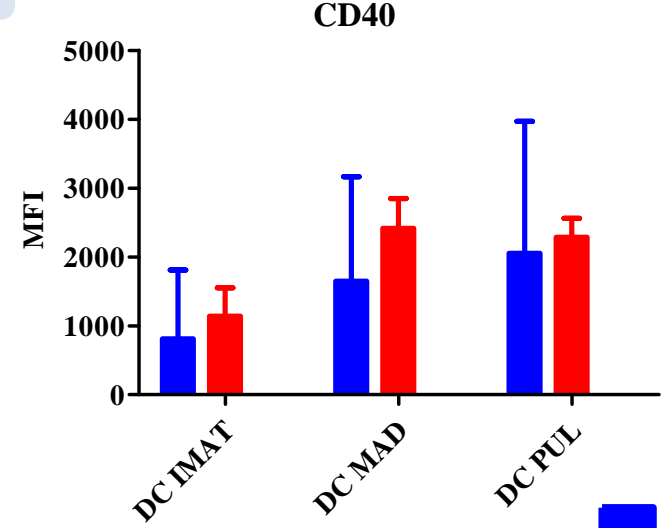

B

CD1a

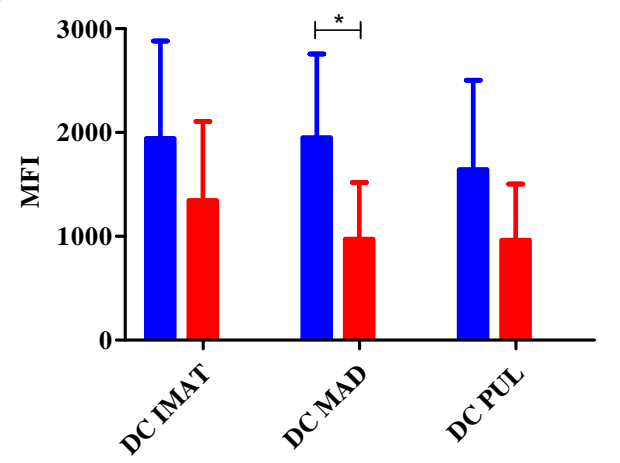

D

CD86

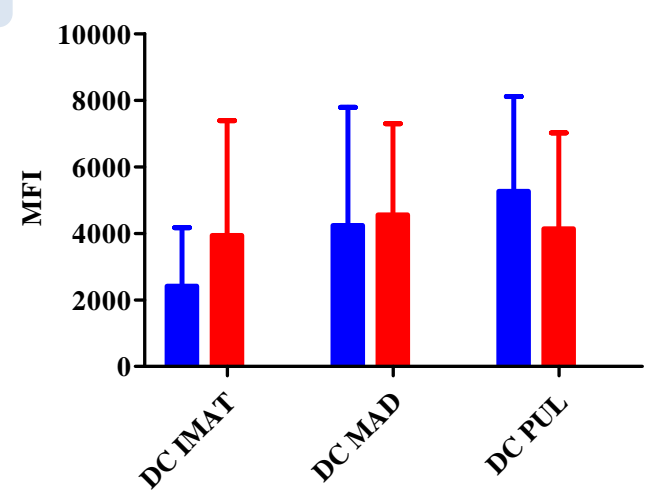

$\mathbf{F}$

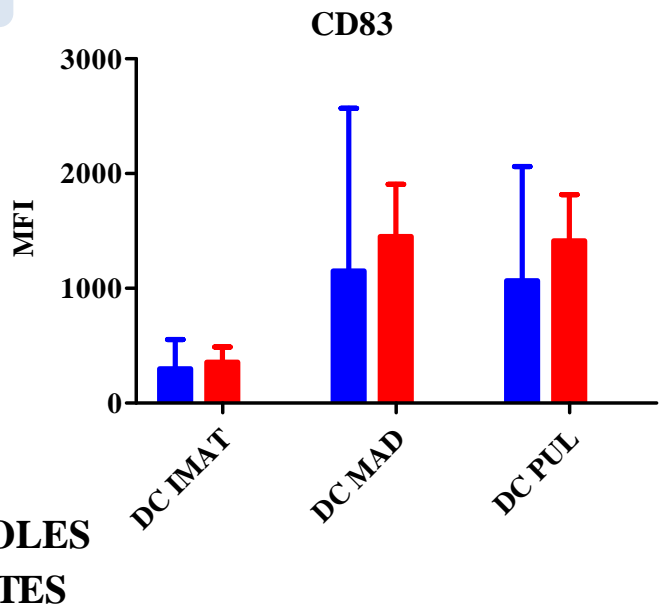

A análise da expressão de marcadores específicos foi realizada na população de DCs CD11c ${ }^{+} / C D 14$, separadas primeiramente de acordo com o tamanho e a granulosidade celular. As barras representam as médias e respectivos desvios padrão referentes aos resultados obtidos nos 5 experimentos realizados com indivíduos sadios (controles) e nos 10 experimentos realizados com indivíduos $\mathrm{HIV}^{+}$em relação aos marcadores HLADR (A), CD1a (B), CD80 (C), CD86 (D), CD40 (E) e CD83 (F). 
Para uma melhor análise da capacidade do HIV quimicamente inativado em induzir alterações fenotípicas e funcionais nas DCs, uma porção dessas células geradas, provenientes de amostras de indivíduos infectados pelo HIV, foi tratada somente com o vírus inativado, sem adição do coquetel de citocinas pró-inflamatórias (DCs imaturas/virus).

Além disso, para aprofundar o estudo sobre a enzima de interesse, uma porção das DCs pulsadas e ativadas foi tratada com $100 \mu \mathrm{M}$ de 1-metil-triptofano (1-MT), bloqueador competitivo de IDO, 24 horas antes da indução de maturação (DCs maduras/1-MT e DCs pulsadas/1-MT). A análise do perfil fenotípico dessas populações celulares também foi realizada.

Não foi possível evidenciar diferença significativa com relação ao perfil fenotípico das DCs imaturas estimuladas ou não com HIV quimicamente inativado (figura 9A) ou das DCs ativadas, maduras (figura 9B) e pulsadas (figura 9C), sob influência ou não de 1-metiltriptofano. 
Figura 9 - Perfil fenotípico de DCs imaturas na presença de HIV inativado e DCs ativadas sob influência de 1-metil-triptofano.

A

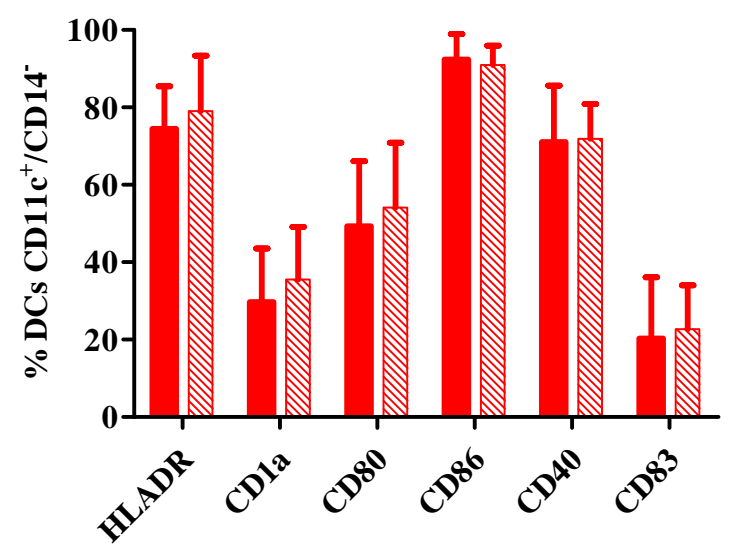

DCs IMATURAS

DCS IMATURA/VIRUS

\section{B}

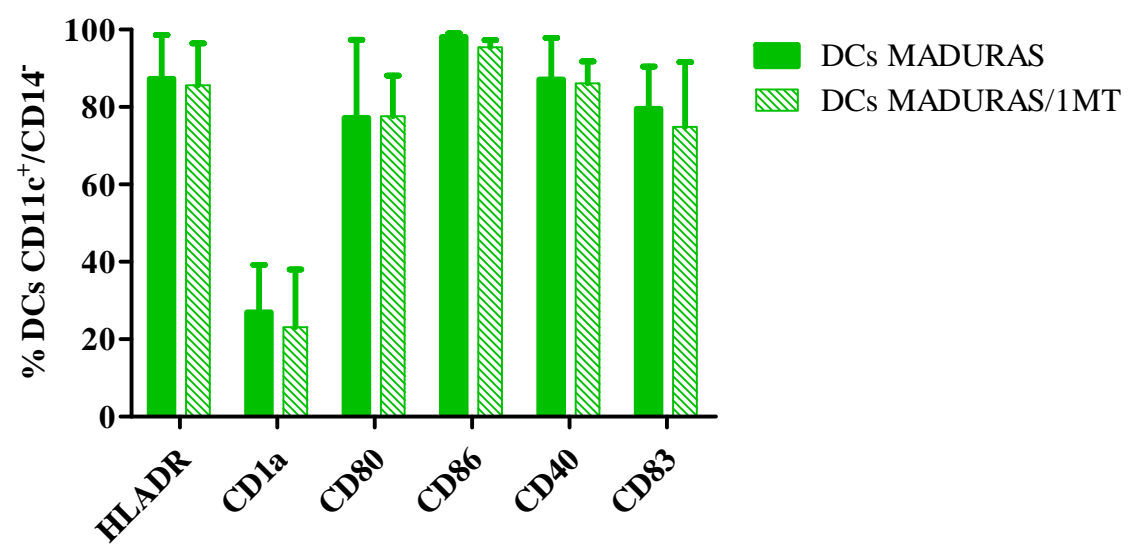

C

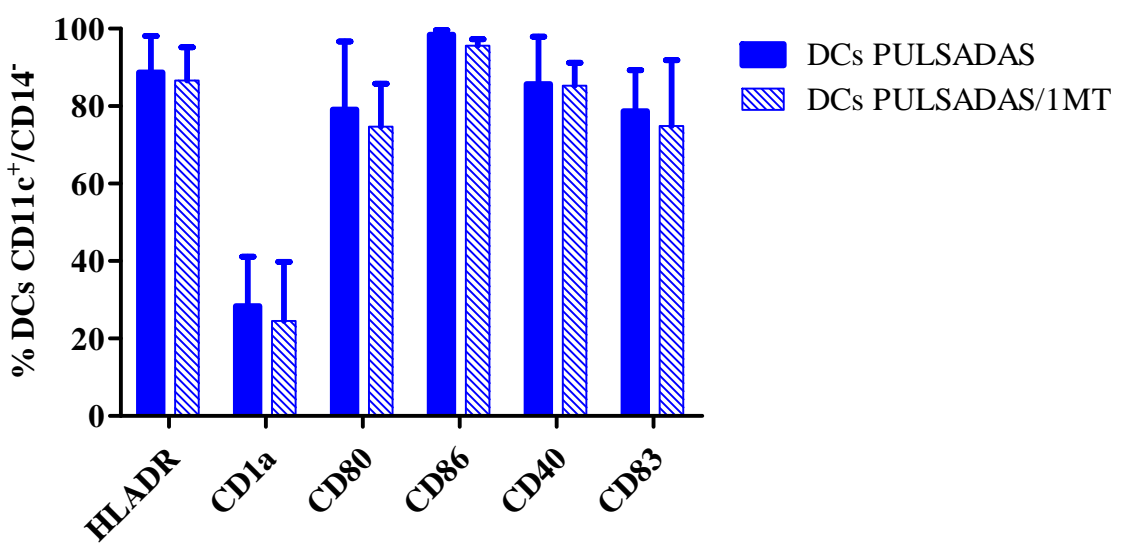

A análise da expressão de marcadores específicos foi realizada na população de DCs CD11c ${ }^{+} / \mathrm{CD}^{-} 4^{-}$, separadas primeiramente de acordo com o tamanho e a granulosidade celular. As barras representam as médias e respectivos desvios padrão referentes aos resultados obtidos em 5 experimentos realizados com indivíduos $\mathrm{HIV}^{+}$. (A) Perfil fenotípico de DCs imaturas estimuladas ou não com HIV quimicamente inativado. (B) Perfil fenotípico de DCs maduras e pulsadas (C) sob influência ou não de 1-metil-triptofano. 


\subsection{Detecção de IDO em monócitos e DCs por citometria de fluxo}

Com relação à análise da expressão da enzima IDO por citometria de fluxo, a marcação intracelular nos monócitos e nas DCs geradas foi realizada como descrito anteriormente. Primeiramente, as populações foram analisadas com relação ao seu tamanho e complexidade interna dos grânulos (FSC x SSC). Em seguida, as células CD11 ${ }^{+/} \mathrm{CD} 14^{+}$ (monócitos) e CD11c ${ }^{+/} \mathrm{CD} 14^{-}$(DCs) foram identificadas e selecionadas para análise da expressão da enzima IDO.

As DCs se mostraram muito sensíveis ao processo de marcação intracelular, ou seja, houve uma grande queda na viabilidade celular durante a realização dos ensaios. Assim, alguns protocolos distintos foram testados para identificar o menos invasivo e prejudicial às DCs, mas que ao mesmo tempo garantisse a detecção da enzima de interesse (dados não mostrados).

Para a padronização desse ensaio, foi utilizado um protocolo de ativação com IFN- $\gamma$, um potente estímulo para indução da enzima IDO (57), com o objetivo de avaliar a eficácia do processo de marcação intracelular.

Na figura 10, é possível observar que o estímulo com IFN- $\gamma$, em duas doses (100UI e 1000UI) e por dois períodos distintos ( 24 e 48 horas), foi capaz de induzir uma expressão elevada de IDO em DCs quando comparado ao protocolo padrão de ativação utilizado, evidenciando que o processo de marcação intracelular foi bem realizado.

Com relação à detecção de IDO por citometria de fluxo, foi possível identificar a porção de monócitos e de DCs que expressava IDO, confirmando que o processo de permeabilização da membrana e marcação intracelular foi bem sucedido. 
Figura 10 - Protocolos de ativação para indução da expressão da enzima IDO.

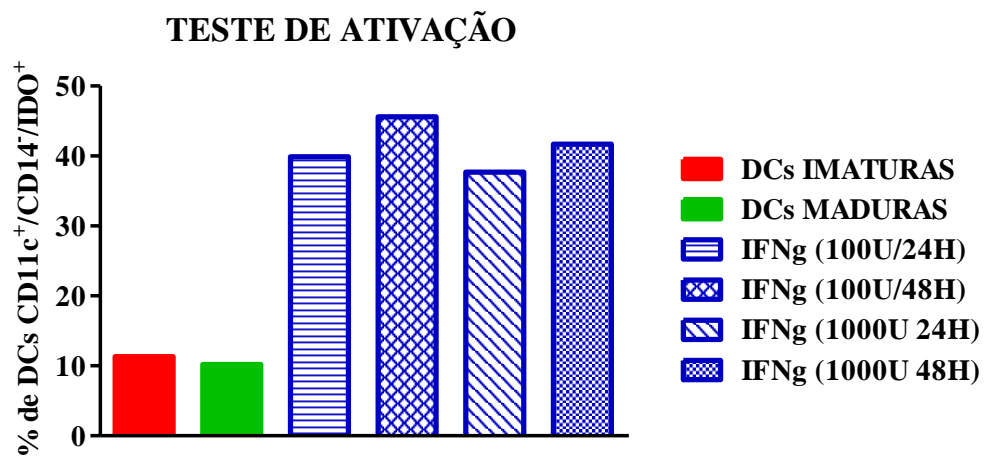

DCs imaturas foram ativadas com o coquetel tradicional de citocinas pró-inflamatórias (DCs maduras) e com $100 \mathrm{U}$ ou $1000 \mathrm{U}$ de IFN- $\gamma$ por 24 ou 48 horas. O gráfico representa um experimento realizado com amostra de doador sadio.

Uma vez padronizado o protocolo, investigamos a expressão de IDO em monócitos e DCs de indivíduos HIV+ e sadios.

Os resultados obtidos estão representados na figura 11. Com relação aos indivíduos sadios observamos que a expressão de IDO foi reduzida à medida em que os monócitos foram diferenciados em DCs. Além disso, os níveis de IDO se mantiveram estáveis, independente de seu estágio de ativação ou pulso viral. Por sua vez, em indivíduos infectados, a expressão de IDO foi ligeiramente reduzida quando os monócitos foram diferenciados em DCs imaturas, entretanto houve um significativo aumento na expressão desta enzima quando as DCs foram ativadas e/ou pulsadas com os vírus.

Consequentemente, a comparação do perfil de expressão de IDO entre pacientes e controles mostra perfis distintos entre estes dois grupos, com percentuais de DCs maduras e DCs pulsadas expressando IDO significativamente mais altos em pacientes com relação aos controles sadios. 
Figura 11 - Análise por citometria de fluxo da expressão da enzima IDO em monócitos e DCs de indivíduos sadios e $\mathrm{HIV}^{+}$.
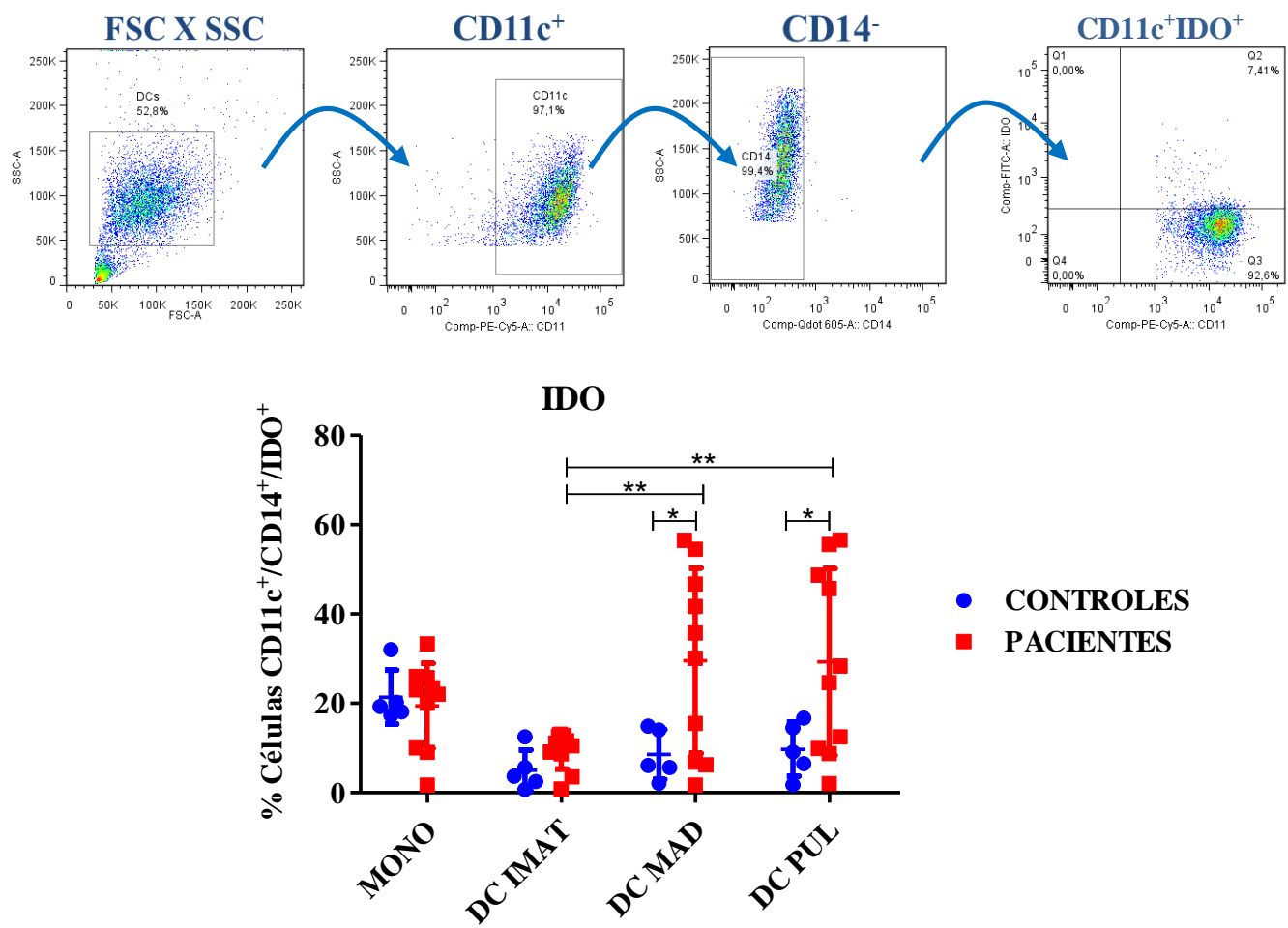

As células foram separadas primeiramente de acordo com tamanho (FSC) e granulosidade (SSC). Os dot plots representam a análise, por citometria de fluxo na população de DCs. A análise da expressão de IDO foi realizada na população de monócitos $\left(\mathrm{CD} 11 \mathrm{c}^{+} / \mathrm{CD} 14^{+}\right)$e de $\mathrm{DCs}\left(\mathrm{CD} 11 \mathrm{c}^{+} / \mathrm{CD} 14^{-}\right)$. Os resultados demonstram a comparação das médias, com respectivos desvios padrão, entre os níveis de IDO encontrados nas DCs de indivíduos sadios (controles), nos 5 experimentos realizados, e de indivíduos infectados pelo HIV (pacientes) nos 10 experimentos realizados. (*) $\mathrm{p}<0,05(* *) \mathrm{p}<0,01$.

Em seguida, para avaliar o efeito do bloqueio de IDO nas DCs procedeu-se ao tratamento destas células com o bloqueador 1-metil-triptofano. Vale lembrar que esses experimentos foram realizados em 5 dos indivíduos do grupo $\mathrm{HIV}^{+}$. Parte das DCs imaturas foi tratada com HIV quimicamente inativado na ausência do coquetel de citocinas pró-inflamatórias e parte das DCs ativadas foi tratada com $100 \mu \mathrm{M}$ de 1-metil-triptofano (1MT) 24 horas antes do processo de ativação celular. As células foram então avaliadas quanto à expressão de IDO. Os resultados encontrados estão representados na figura 12.

Embora não se tenha alcançado significância estatística, observa-se uma tendência à redução na expressão de IDO tanto em DCs maduras quanto pulsadas, tratadas com 1MT, em comparação aos seus respectivos controles não tratados, sendo que a redução parece mais acentuada nas amostras pulsadas com HIV. Vale destacar que o bloqueio na expressão da 
enzima IDO não foi total. Desse modo, os mecanismos associados a ação dessa enzima no microambiente celular não podem ser descartados após o tratamento com 1-MT.

Figura 12 - Análise por citometria de fluxo da expressão da enzima IDO em DCs de indivíduos $\mathrm{HIV}^{+}$.

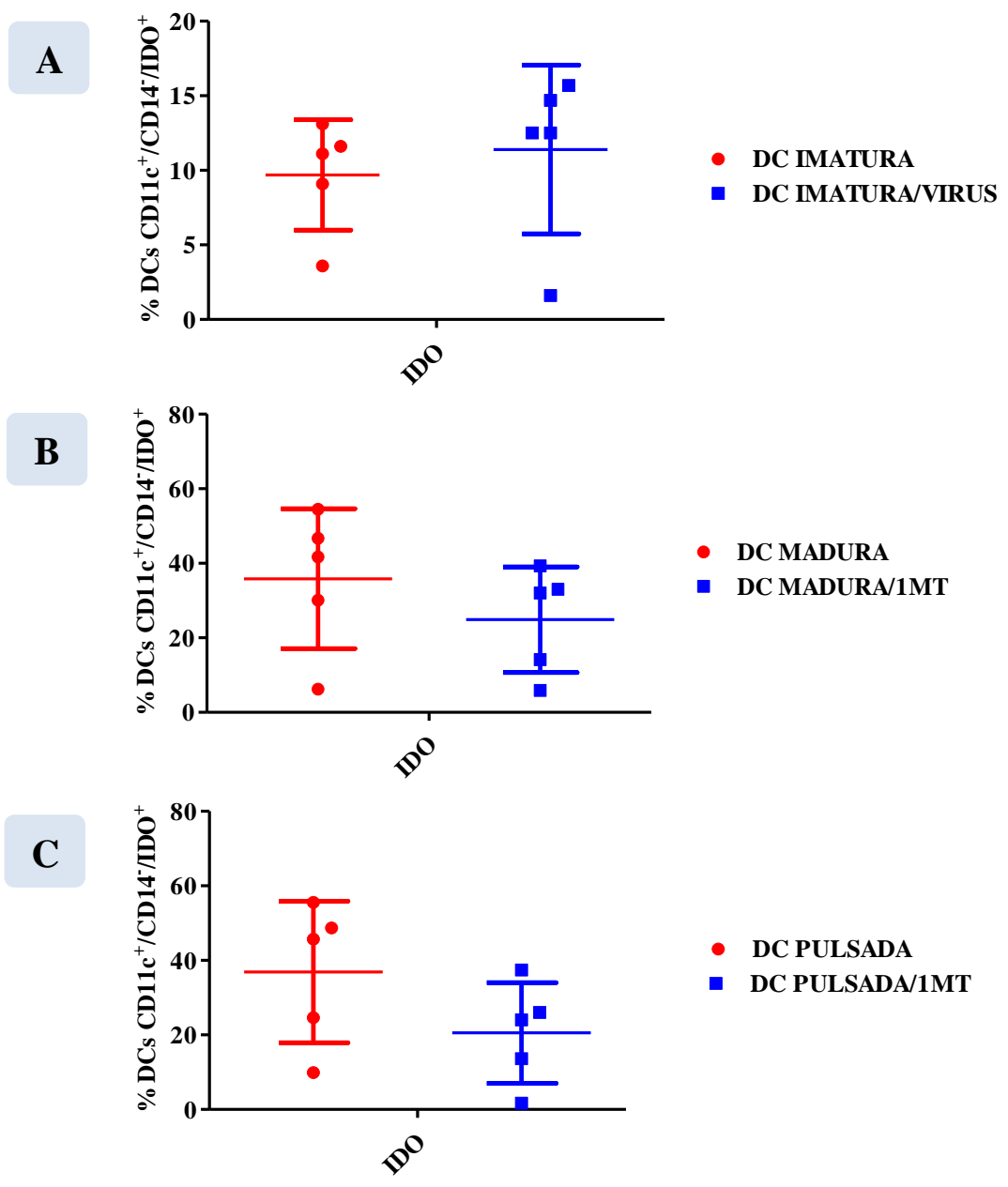

A análise da expressão de IDO foi realizada na população de DCs CD11 ${ }^{+} / \mathrm{CD} 14^{-}$, separadas primeiramente de acordo com o tamanho e a granulosidade celular. Os resultados demonstram a comparação das médias, com respectivos desvios padrão obtidos em 5 experimentos realizados com indivíduos $\mathrm{HIV}^{+}$. (A) DCs imaturas estimuladas ou não com HIV quimicamente inativado. (B) DCs maduras e pulsadas (C) sob influencia ou não de 1-metil-triptofano.

\subsection{Expressão de RNAm de IDO por PCR em tempo real}

A enzima IDO foi avaliada também com relação à expressão de seu RNAm por PCR em tempo real, utilizando como controle endógeno a expressão de RNAm da $\beta$-actina. Para tanto a expressão do RNAm de IDO foi normalizada com a expressão do RNAm endógeno da 
$\beta$-actina nos monócitos e nos diferentes estágios de maturação das DCs e os resultados foram expressos de acordo com a formula $2^{-\Delta \Delta c t}$.

Inicialmente analisamos a variação nos níveis de expressão de RNAm para IDO em DCs imaturas com relação aos monócitos em amostras obtidas de indivíduos $\mathrm{HIV}^{+}$e sadios. Os resultados obtidos estão representados na figura 13.

Tanto no grupo de indivíduos sadios quanto no grupo de indivíduos $\mathrm{HIV}^{+}$, as DCs imaturas demonstram uma tendência em expressar níveis menores de RNAm de IDO quando comparadas aos monócitos, ou seja, durante o processo de diferenciação de monócitos em DCs há uma redução na expressão de RNAm de IDO. Além disso, a comparação entre os níveis de expressão em pacientes e controles mostra uma tendência de expressão relativamente menor em DCs imaturas de pacientes infectados pelo HIV.

Figura 13 - Expressão relativa do RNAm de IDO em monócitos e DCs imaturas.

\section{IMATURA X MONÓCITOS}

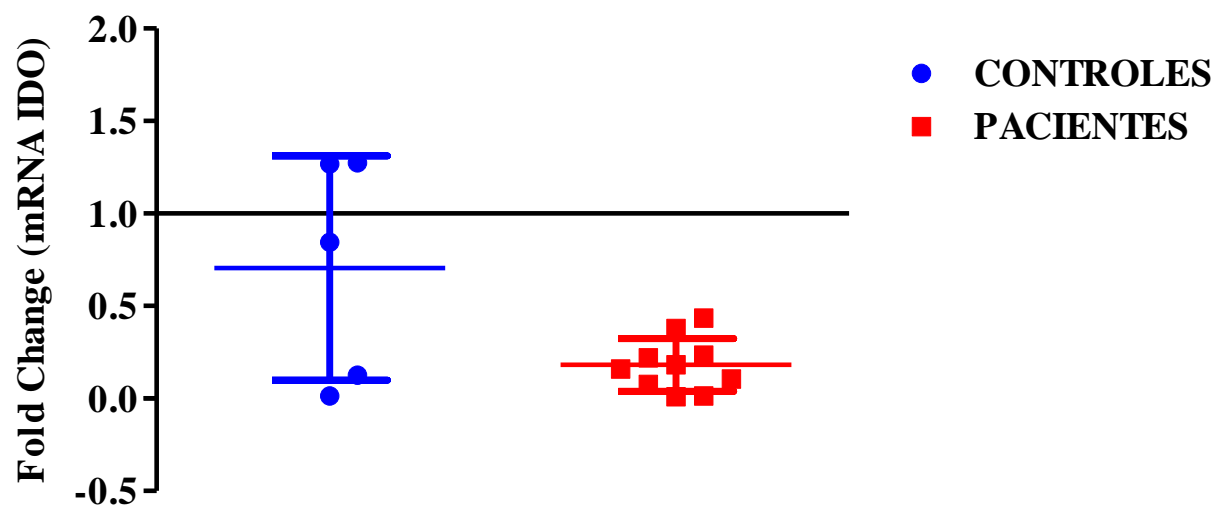

Os dados de expressão do RNAm de IDO nas DCs imaturas foram normalizados com os dados do RNAm endógeno da $\beta$-actina e relacionados com a expressão encontrada nos monócitos. Os resultados representam a comparação das médias, com os respectivos desvios padrão, entre os 5 experimentos realizados em indivíduos sadios (controles) e os 10 experimentos realizados em indivíduos $\mathrm{HIV}^{+}$(pacientes).

Em seguida, analisamos a expressão do RNAm de IDO em DCs ativadas com relação às DCs imaturas em amostras provenientes de indivíduos sadios e $\mathrm{HIV}^{+}$.

Os resultados estão representados na figura 14. Observamos que o estímulo de DCs com citocinas pró-inflamatórias, independente da presença de vírus, leva a uma tendência de aumento na expressão de RNAm de IDO, com relação ao estágio de DC imatura. 
Figura 14 - Expressão relativa do RNAm de IDO em DCs.

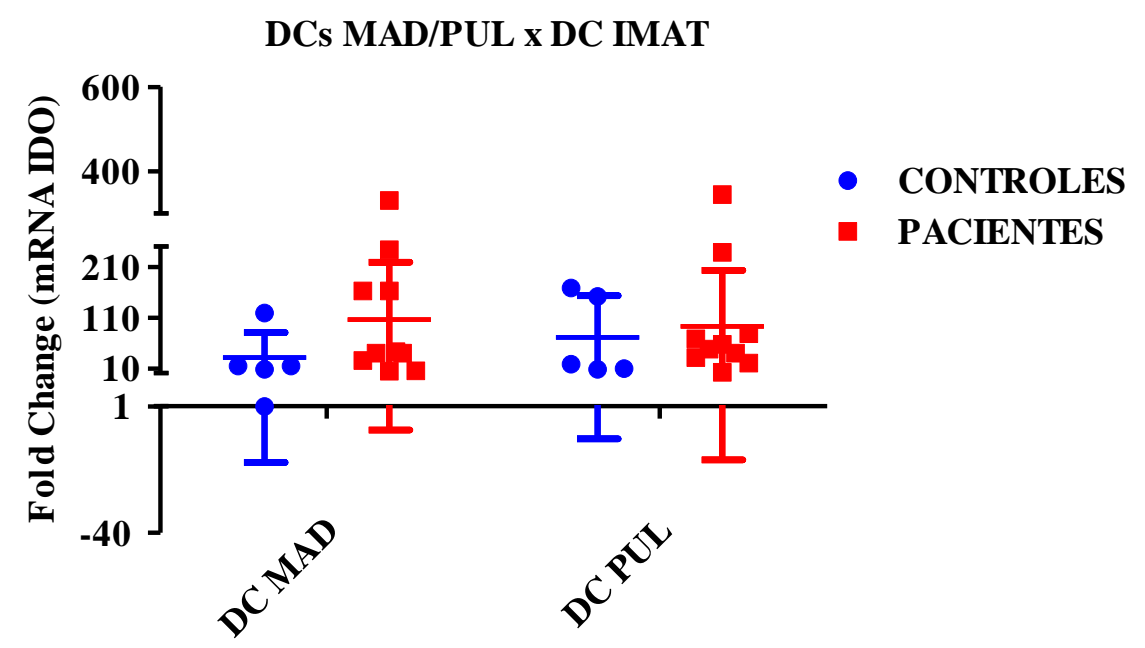

Os dados de expressão do RNAm de IDO foram normalizados com os dados do RNAm endógeno da $\beta$-actina e relacionados com a expressão encontrada nas DCs imaturas. Os resultados representam a comparação das médias entre os 5 experimentos realizados em indivíduos sadios (controles) e os 10 experimentos realizados em indivíduos infectados pelo HIV (pacientes).

Por sua vez, a comparação entre os níveis de expressão de IDO mostra que a análise da média do grupo de indivíduos $\mathrm{HIV}^{+}$apresenta uma tendência a níveis maiores de expressão do RNAm de IDO nas DCs maduras e pulsadas quando comparadas as mesmas DCs no grupo de indivíduos sadios.

\subsection{Resposta linfoproliferativa induzida DCs}

O potencial de indução de resposta linfoproliferativa foi analisado em DCs imaturas, maduras e pulsadas, além da porção de DCs imaturas estimulada com HIV quimicamente inativado e de DCs ativadas submetidas ao tratamento com 1-MT. Esses experimentos foram realizados, como descrito anteriormente, em 4 amostras de indivíduos infectados pelo HIV. Os resultados estão representados nas figuras seguintes. 
Figura 15 - Resposta linfoproliferativa de células TCD4 ${ }^{+}$estimuladas por DCs.

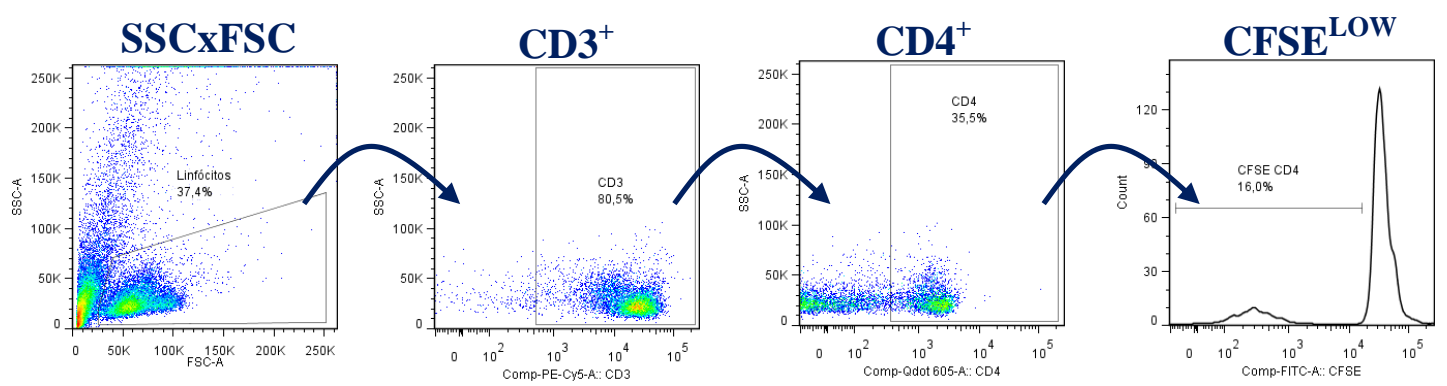

\section{CÉLULAS TCD4 ${ }^{+}$}

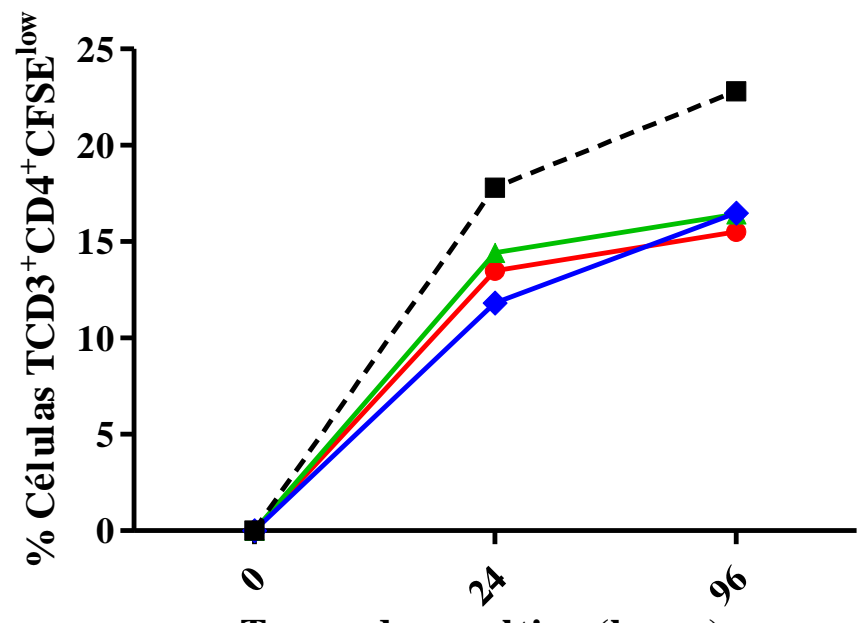

$\rightarrow$ DC IMATURA

$\leftarrow$ DC MADURA

$\neg$ DC PULSADA

$-\mathbf{C +}$

Tempo de cocul tivo (horas)

As células foram separadas primeiramente de acordo com tamanho (FSC) e granulosidade (SSC). Os dot plots representam a análise, por citometria de fluxo na população de linfócitos $\mathrm{CD} 4^{+}$. A análise da resposta linfoproliferativa de células TCD4+ estimuladas com DCs, em diferentes estágios de maturação, foi realizada com base na intensidade de fluorescência do marcador CFSE. As células CFSE ${ }^{\text {low }}$ representam a porção celular que passou por processo de divisão mitótica induzida pelo estímulo com as DCs. O gráfico representa a média da porcentagem de células $\mathrm{TCD}^{+}{ }^{+} \mathrm{TCD} 4^{+} \mathrm{CFSE}^{\text {low }}$ após 0,24 e 96 horas de cocultivo com DCs autólogas, de 5 experimentos realizados com indivíduos $\mathrm{HIV}^{+}$. O controle positivo foi constituído por linfócitos estimulados por 72 horas com $5 \mu \mathrm{g} / \mathrm{mL}$ de PHA.

A mesma estratégia de gates, representada na figura 15, foi utilizada para análise da população $\mathrm{CD}^{+}$e os resultados estão descritos na figura 16. 
Figura 16 - Resposta linfoproliferativa de células TCD8 ${ }^{+}$estimuladas por DCs.

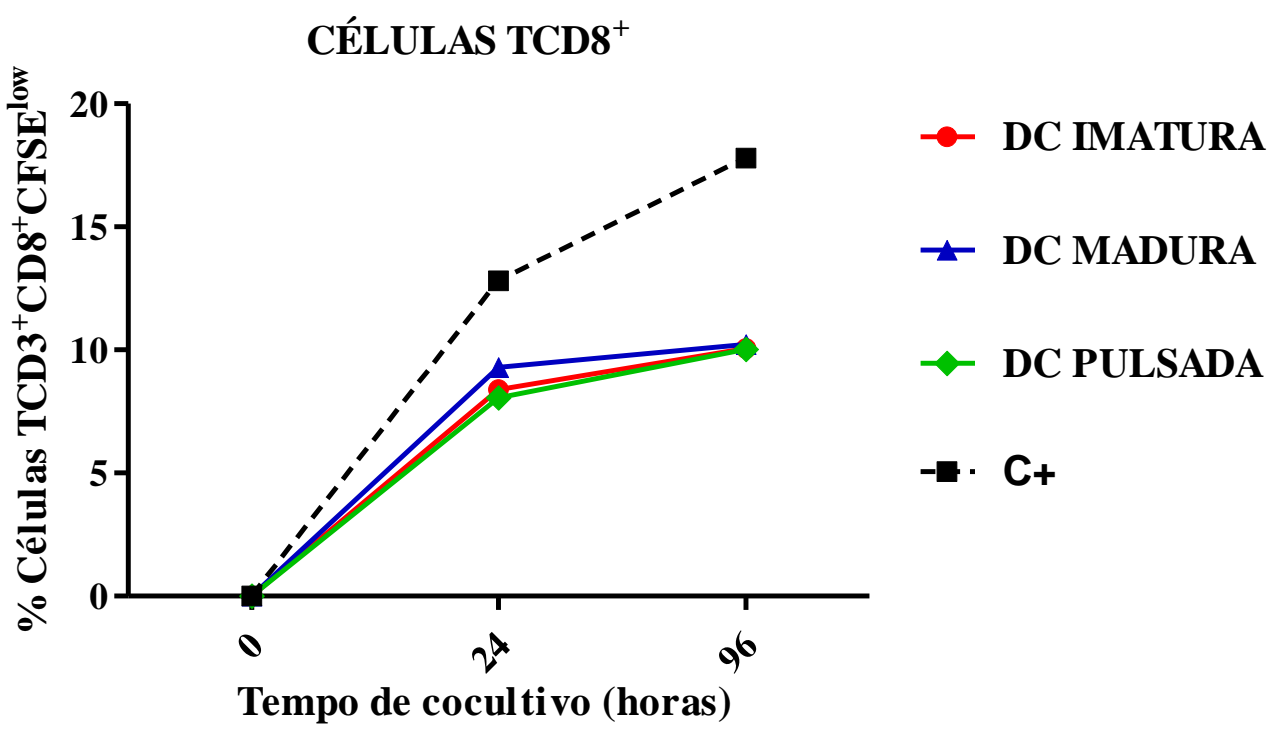

A análise da resposta linfoproliferativa de células $\mathrm{TCD}^{+}$estimuladas com DCs, em diferentes estágios de maturação, foi realizada com base na intensidade de fluorescência do marcador CFSE. As células CFSE ${ }^{\text {low }}$ representam a porção celular que passou por processo de divisão mitótica induzida pelo estímulo com as DCs. O gráfico representa a média da porcentagem de células TCD $3^{+} \mathrm{TCD}^{+} \mathrm{CFSE}^{\text {low }}$ após 0,24 e 96 horas de cocultivo com DCs autólogas, de 5 experimentos realizados com indivíduos $\mathrm{HIV}^{+}$. O controle positivo foi constituído por linfócitos estimulados por 72 horas com $5 \mu \mathrm{g} / \mathrm{mL}$ de PHA.

Com base nos resultados demonstrados, observou-se que o estímulo com DCs, independente do seu estágio de maturação, foi capaz de induzir uma resposta linfoproliferativa em células $\mathrm{TCD}^{+}$(figura 15) e $\mathrm{TCD}^{+}$(figura 16) após 24 e 96 horas de cocultivo, embora não tenha sido evidenciada diferença significativa entre as culturas.

Ainda com relação à indução de proliferação celular de linfócitos autólogos, não foi possível observar diferença significativa entre o estímulo com DCs imaturas estimuladas ou não com HIV quimicamente inativado, tanto em células $\mathrm{TCD}^{+}$(figura 17A) quanto em células TCD $8^{+}$(figura 17B).

Em relação às DCs maduras (figuras 17C e 17D) e pulsadas (figuras 17E e 17F) foi possível notar uma tendência de aumento de resposta proliferativa dos linfócitos $\mathrm{TCD}^{+} \mathrm{e}$ $\mathrm{TCD}^{+}$estimulados com as DCs tratadas com 1-metil-triptofano, quando comparadas ao estímulo de DCs sem a influência desse bloqueador. Vale ressaltar que o desvio padrão desses ensaios foi elevado (dados não mostrados), prejudicando a análise desses resultados. 
Figura 17 - Resposta linfoproliferativa de $\mathrm{TCD}^{+}$e $^{\mathrm{TCD}} 8^{+}$estimuladas com DCs

\section{A}

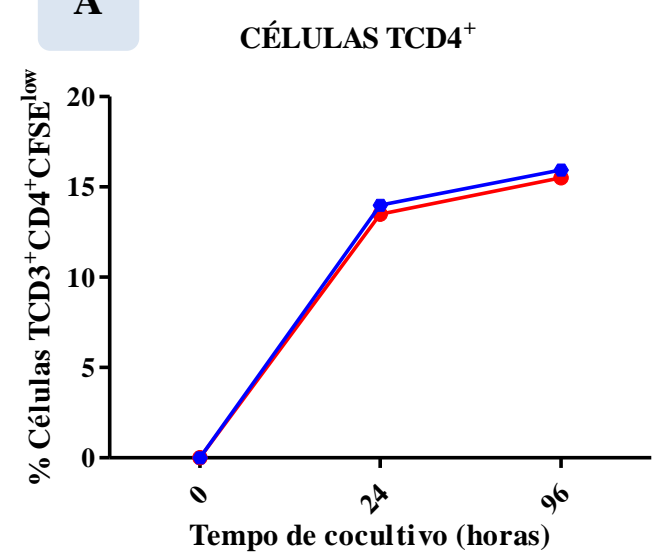

C
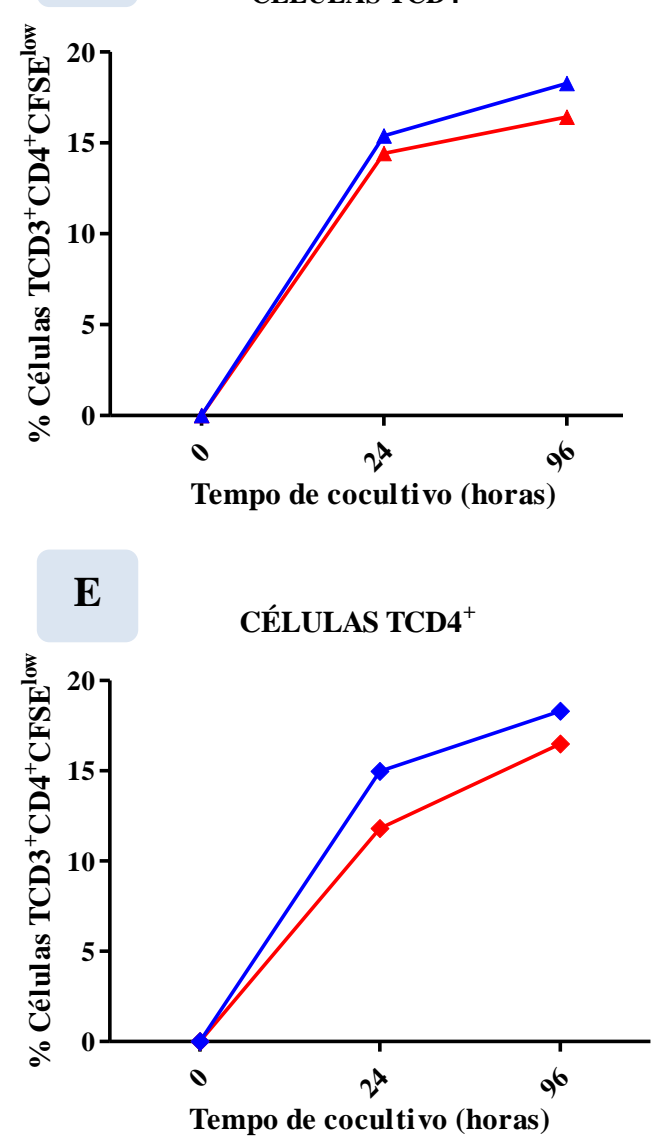

B

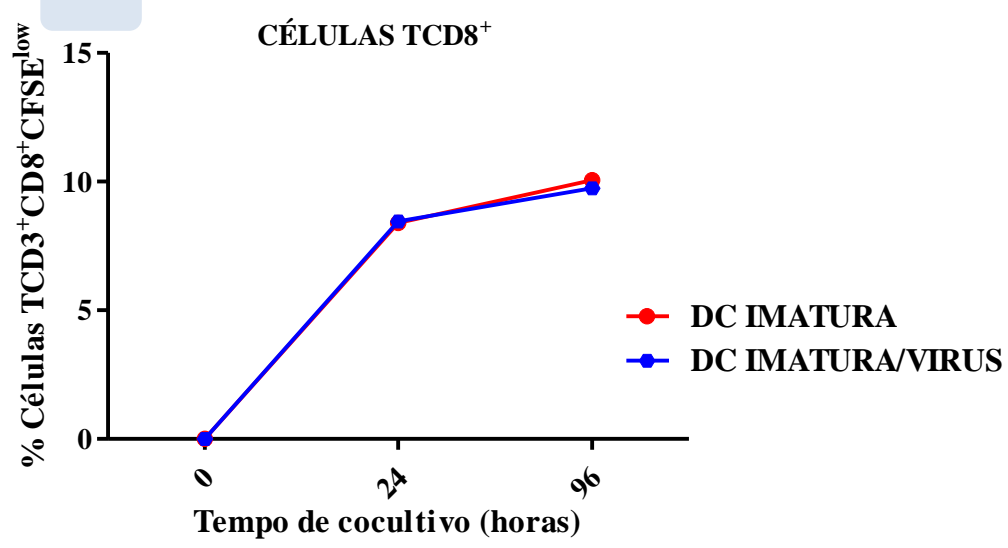

D

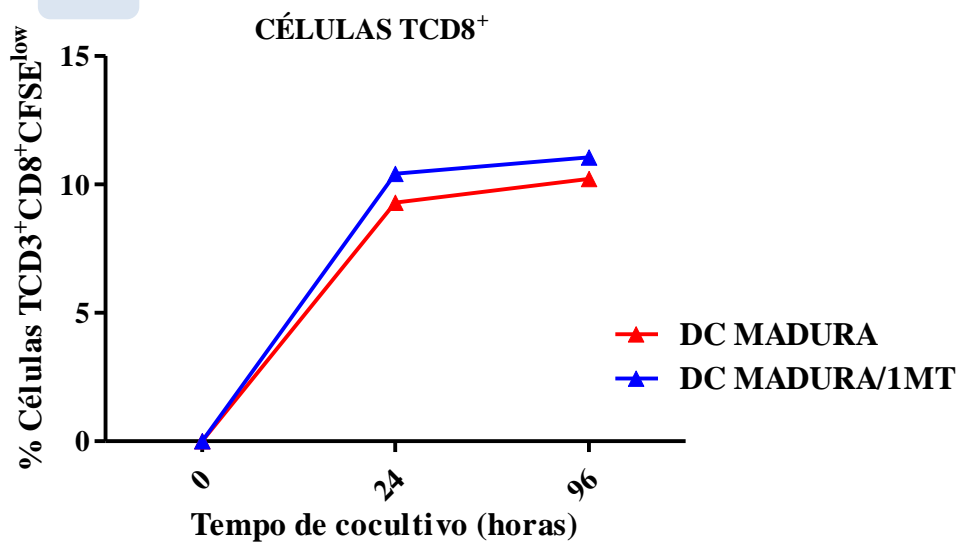

$\mathbf{F}$

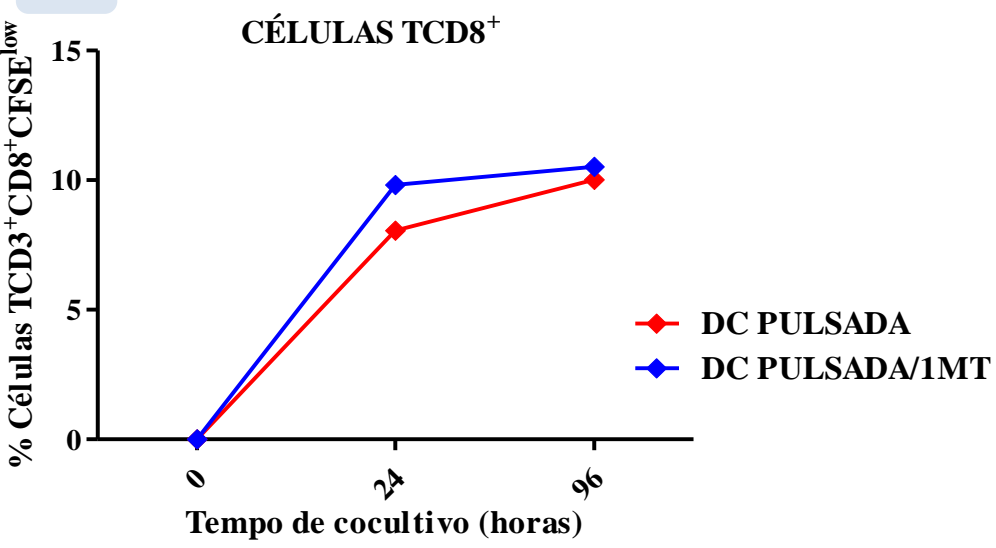

A análise da resposta linfoproliferativa de células $\mathrm{TCD}^{+}\left(\mathrm{A}, \mathrm{C}\right.$ e E) e $\mathrm{TCD} 8^{+}(\mathrm{B}, \mathrm{D}$ e F) estimuladas com DCs, em diferentes estágios de maturação, foi realizada com base na intensidade de fluorescência do marcador CFSE. As células CFSE $^{\text {low }}$ representam a porção celular que passou por processo de divisão mitótica induzida pelo estímulo com as DCs. O gráfico representa a média da porcentagem de células T após 0,24 e 96 horas de cocultivo com DCs autólogas imaturas, estimuladas ou não com HIV quimicamente inativado (A e B), maduras (C e D) e pulsadas (E e F) tratadas ou não com 1-metil-triptofano. 


\subsection{Atividade polifuncional de linfócitos T autólogos estimulados por DCs}

A capacidade das DCs, provenientes de amostras de indivíduos infectados, em induzir resposta celular in vitro foi avaliada em ensaio de cocultivo, utilizando linfócitos autólogos. Para tanto, foi monitorado o estímulo de células $\mathrm{TCD}^{+}$e $\mathrm{TCD}^{+}$produtoras de marcador de desgranulação citotóxica (CD107a), citocinas pró-inflamatórias (IFN- $\gamma$, IL-2, TNF- $\alpha$ ) e quimiocina (MIP-1 $\beta$ ).

Dada a necessidade de detecção intracelular simultânea destas citocinas a fim de caracterizar a polifuncionalidade da resposta de linfócitos e, considerando que cada citocina possui uma cinética de produção particular, realizamos um ensaio para análise individual da cinética de produção de cada uma das citocinas, as quais foram analisadas em 6, 24, 48 e 96 horas de cocultivo (apêndice). Tomados em conjunto, os dados obtidos mostraram que os tempos ideais para o monitoramento dos ensaios de cocultivo eram 24 e 96 horas, pois permitiram a detecção de todos os mediadores propostos.

Assim, procedemos aos ensaios de cocultivo, sendo que a produção de cada um dos mediadores imunológicos citados acima após 24 e 96 horas de cocultivo foi normalizada com a produção basal observada nos linfócitos autólogos na ausência de estímulo. Essa produção basal foi determinada após cada um dos tempos de cultura de linfócitos autólogos, na ausência de estímulo e presença de Brefeldina A. Vale lembrar que, para os ensaios realizados em 96 horas de cocultivo, a expressão do marcador CD107a não foi realizada. Nesse contexto, as análises referentes a esse último tempo de cocultivo levam em consideração a produção de apenas 4 mediadores (IFN- $\gamma$, IL-2, TNF- $\alpha$ e MIP-1 $\beta$ ).

A figura 18 representa o esquema inicial de análise dos dados obtidos baseada na expressão individual e simultânea dos mediadores estudados em células TCD4 ${ }^{+}$e TCD8 ${ }^{+}$ (análise booleana). Lembrando que, em 24 horas de cocultivo foram analisados 5 mediadores (CD107a, IFN- $\gamma$, IL-2, TNF- $\alpha$ e MIP-1 $\beta$ ) e em 96 horas, apenas 4 mediadores. As análises comparativas entre os dois tempos de cultivo levam em consideração os 4 mediadores presentes em ambos os casos.

A intensidade da resposta $\mathrm{T}$ celular induzida pelas DCs em diferentes estágios de ativação foi avaliada pela produção monofuncional (1 citocina ou quimiocina) ou polifuncional (2 ou mais citocinas ou quimiocina) dos mediadores imunológicos avaliados, lembrando que a resposta celular de maior intensidade corresponde a produção simultânea de 5 ou 4 mediadores (dependendo do tempo de cocultivo analisado) e, a de menor intensidade, apenas um mediador produzido de forma isolada. 
Figura 18: Análise booleana de produção mono e polifuncional de mediadores imunológicos por linfócitos TCD4 ${ }^{+}$e TCD $8^{+}$.

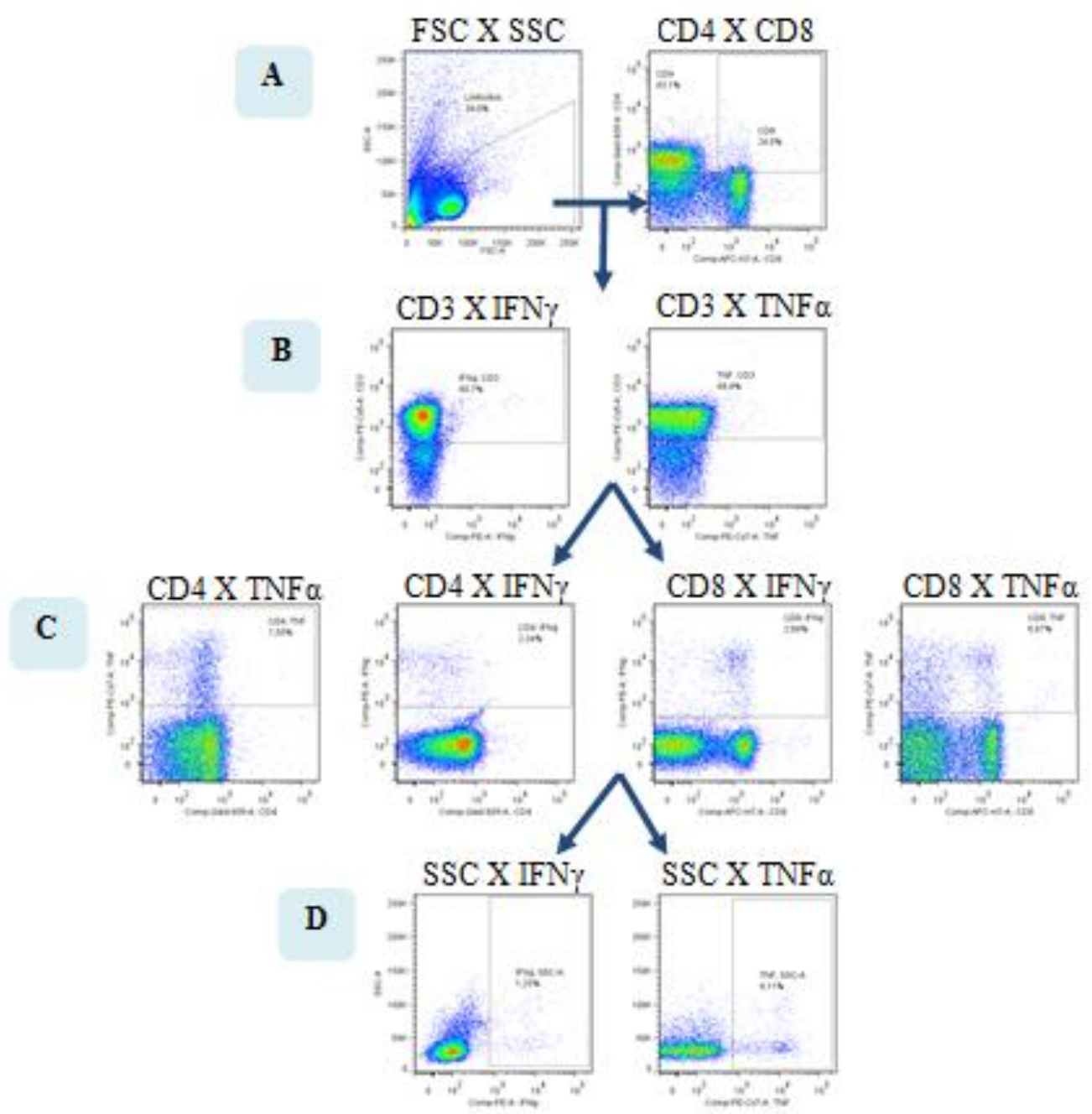

O gráfico representa o esquema de atividade mono e polifuncional de linfócitos em estado basal, na ausência de estímulo, após 4 horas de cultura. (A) As células foram analisadas de acordo com tamanho e complexidade interna (FSC X SSC) e posteriormente os linfócitos $\mathrm{TCD}^{+}$e $\mathrm{TCD}^{+}$foram separados. (B) Em seguida, os linfócitos $\mathrm{T}$ foram isolados pela expressão de marcador específico (CD3) e as subpopulações seguintes foram analisadas de acordo com a expressão dos marcadores CD4 e CD8. (C e D) A expressão individual e simultânea de cada um dos mediadores analisados foi realizada nas duas subpopulações previamente isoladas (análise booleana). Vale lembrar que nesse gráfico apenas dois mediadores imunológicos foram representados, porém a mesma análise foi realizada para os demais mediadores não demonstrados.

Nas figuras seguintes, os diagramas de setores circulares mostram a proporção relativa dos mediadores imunes produzidos por células T, combinados em grupos de um a cinco, sendo que a cor azul representa uma resposta monofuncional, ou seja, apenas um tipo de citocina produzida, as cores verde, amarela, azul, vermelha e rosa representam a resposta polifuncional respectivamente com 2, 3, 4 e 5 citocinas produzidas simultaneamente pelas células 
analisadas. Cada diagrama representa um dos estímulos utilizados para a indução de produção das citocinas, quais sejam DCs imaturas ou DCs imaturas/virus, DCs maduras ou DCs maduras/1MT, DCs pulsadas ou DCs pulsadas/1MT ou SEB (controle positivo).

Os mesmos dados estão representados no gráfico de barras verticais. As quatro cores representam a porcentagem de células $\mathrm{T}$ respondedoras aos diferentes estímulos em relação a cada uma das combinações possíveis entre os cinco mediadores imunológicos estudados. As barras horizontais representam as combinações de cinco (rosa), quatro (vermelho), três (amarelo), duas (verde) ou uma (azul) função exercida pelas células efetoras, assim como representado no diagrama de setores circulares. Cada ponto representa a produção de CD107a, IL-2, TNF- $\alpha$, IFN- $\gamma$ e/ou MIP-1 $\beta$.

\subsubsection{Atividade polifuncional de linfócitos TCD4+ autólogos estimulados por DCs em 24 horas de cocultivo}

Assim, iniciamos nossa análise com relação às células $\mathrm{TCD} 4^{+}$autólogas estimuladas por 24 horas com DCs imaturas, DCs maduras ou DCs pulsadas, além do controle positivo.

Os resultados estão representados na figura 19. Foi possível observar que a porcentagem de linfócitos capazes de produzir aos menos uma citocina foi semelhante nos três estímulos utilizados (cerca de $60 \%$ das células em cultura). O percentual de células TCD4 ${ }^{+}$capazes de induzir resposta polifuncional foi maior no estímulo com DCs ativadas (cerca de $60 \%$ dos linfócitos analisados) quando comparadas as DCs imaturas (cerca de 50\% dos linfócitos analisados). Corroborando esses dados, a resposta polifuncional de maior intensidade, produção de 5 e 4 mediadores simultaneamente, foi mais elevada nas DCs ativadas, com ênfase nas DCs maduras que foram capazes de estimular $4 \%$ dos linfócitos analisados, enquanto as DCs imaturas induziram uma resposta polifuncional potente em apenas $0,5 \%$ desses linfócitos. As DCs pulsadas, responsáveis pela indução de uma resposta específica, foram capazes de estimular o mesmo perfil de resposta em cerca de $1 \%$ desses mesmos linfócitos. 
Figura 19 - Produção de mediadores imunológicos por linfócitos TCD4 ${ }^{+}$estimulados por 24 horas com DCs em diferentes estágios de ativação.
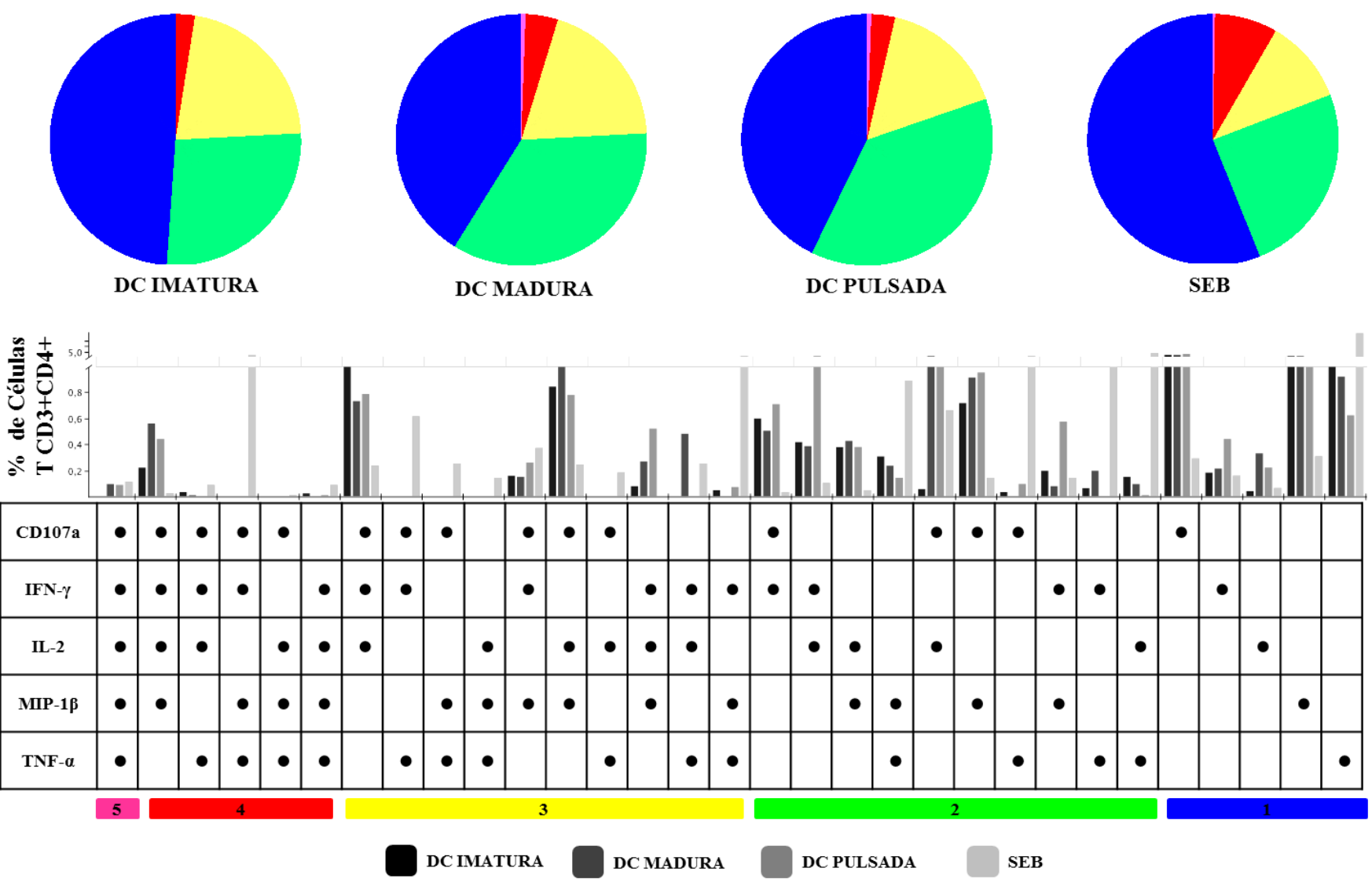

A capacidade das DCs (imaturas, maduras ou pulsadas) em estimular linfócitos autólogos $\mathrm{TCD}^{+}$foi avaliada pela expressão individual e simultânea de moléculas de citotoxicidade (CD107a), citocinas pró-inflamatórias (IL-2, TNF- $\alpha$ e IFN- $\gamma$ ) e quimiocina (MIP-1 $\beta$ ). O diagrama de setores circulares representa a intensidade da resposta $\mathrm{T}$ celular obtida de acordo com o número de mediadores produzidos: 1 (azul), 2 (verde), 3 (amarelo), 4 (vermelho) e 5 (rosa). O gráfico de barras representa a proporção de células $\mathrm{TCD}^{+}$responsáveis pela produção desses mediadores imunológicos, de forma combinada (atividade polifuncional) ou isolada (atividade monofuncional), em cada um dos estímulos utilizados. Os gráficos em barra representam a média de 10 experimentos realizados com amostras de indivíduos $\mathrm{HIV}^{+}$.

Em seguida, analisamos a polifuncionalidade das células $\mathrm{TCD}^{+}$em relação ao estímulo com DCs imaturas tratadas com HIV quimicamente inativado, comparadas as DCs imaturas na ausência do virus, em 24 horas de cocultivo. Vale lembrar que o pulso viral nas DCs imaturas e o tratamento com 1-metil-triptofano foram introduzidos nas amostras dos 5 últimos pacientes $\mathrm{HIV}^{+}$. Desse modo, em todas as comparações envolvendo esses perfis celulares só foram considerados os resultados obtidos nas 5 amostras desses indivíduos. Os resultados estão representados na figura 20. 
Foi possível observar que a porcentagem de linfócitos capazes de produzir ao menos uma citocina foi semelhante nos dois estímulos utilizados (cerca de $60 \%$ das células em cultura). Porém, as DCs imaturas induziram uma resposta polifuncional em 55\% dos linfócitos TCD4 ${ }^{+}$ autólogos, enquanto na porção de DCs estimuladas com HIV quimicamente inativo, essa resposta polifuncional atingiu apenas $20 \%$ das mesmas células. Além disso, a resposta monofuncional predominante no estímulo com DCs imaturas pulsadas com o virus foi caracterizada principalmente pela expressão do marcador de citotoxicidade CD107a. 
Figura 20 - Produção de mediadores imunológicos por linfócitos TCD4 ${ }^{+}$estimulados por 24 horas com DCs imaturas e DCs imaturas/virus.

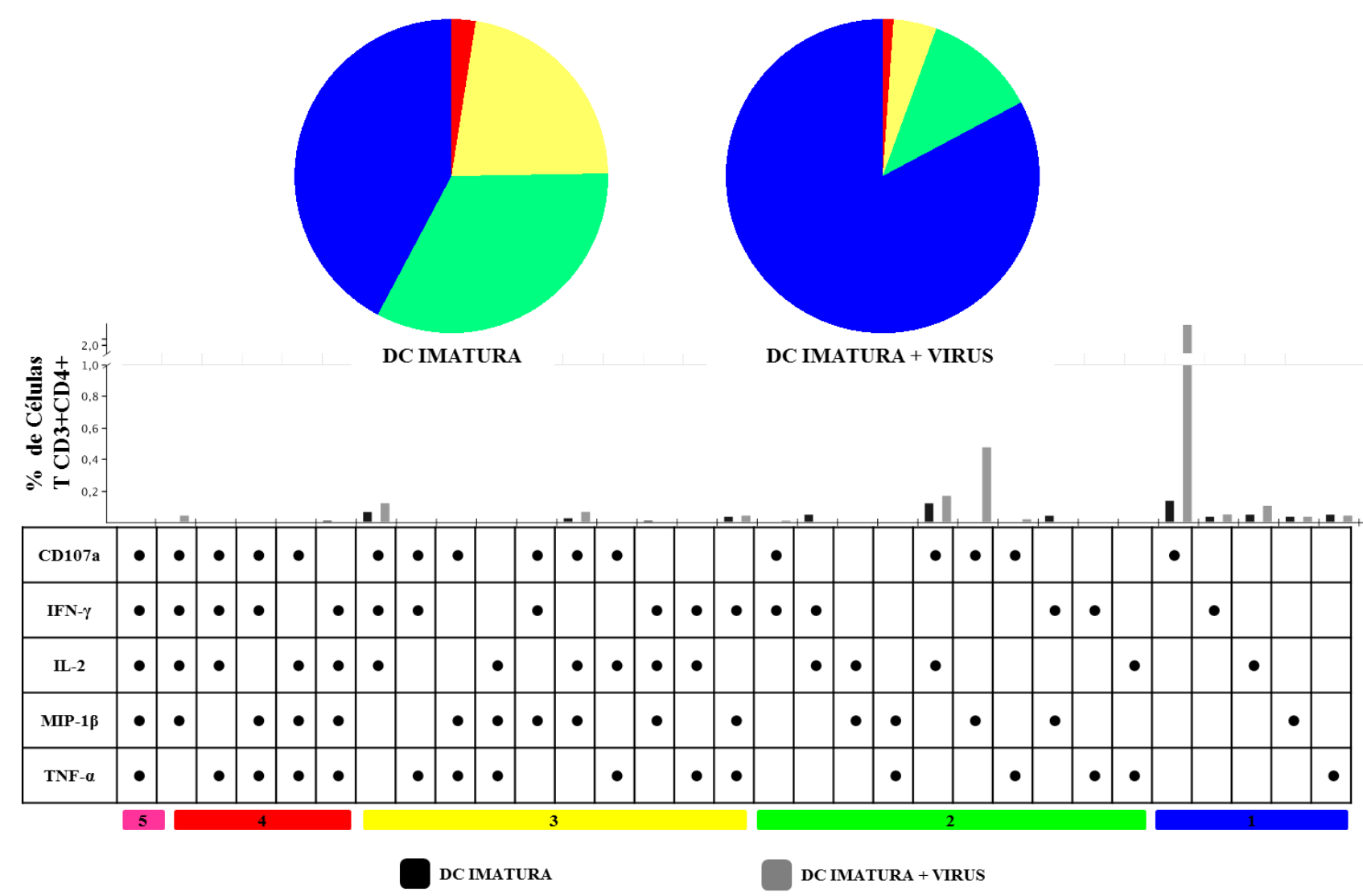

A capacidade das DCs imaturas e imaturas + vírus em estimular linfócitos autólogos TCD4 ${ }^{+}$foi avaliada pela expressão individual e simultânea de moléculas de citotoxicidade (CD107a), citocinas pró-inflamatórias (IL-2, TNF- $\alpha$ e IFN- $\gamma$ ) e quimiocina (MIP-1 $\beta$ ). O diagrama de setores circulares representa a intensidade da resposta T celular obtida de acordo com o número de mediadores produzidos: 1 (azul), 2 (verde), 3 (amarelo), 4 (vermelho) e 5 (rosa). O gráfico de barras representa a proporção de células $\mathrm{TCD}^{+}$responsáveis pela produção desses mediadores imunológicos, de forma combinada (atividade polifuncional) ou isolada (atividade monofuncional), em cada um dos estímulos utilizados. Os gráficos em barra representam a média de 5 experimentos realizados com amostras de indivíduos $\mathrm{HIV}^{+}$.

Para avaliar os efeitos do bloqueio da enzima IDO na indução de polifuncionalidade em linfócitos autólogos, o estímulo com DCs ativadas foi comparado após tratamento com 1metil-triptofano, bloqueador competitivo da enzima de interesse.

$\mathrm{Na}$ figura 21, é possível observar que o perfil de resposta encontrado após 24 de cocultivo é semelhante em ambos os estímulos. Tanto a DCs maduras quanto as DCs maduras tratadas com 1-metil-triptofano foram capazes de induzir resposta monofuncional em cerca de $60 \%$ 
dos linfócitos analisados, o que acarreta uma resposta polifuncional em cerca de $40 \%$ das células TCD4 ${ }^{+}$autólogas.

Figura 21 - Produção de mediadores imunológicos por linfócitos TCD4 ${ }^{+}$estimulados por 24 horas com DCs maduras e DCs maduras/1MT.

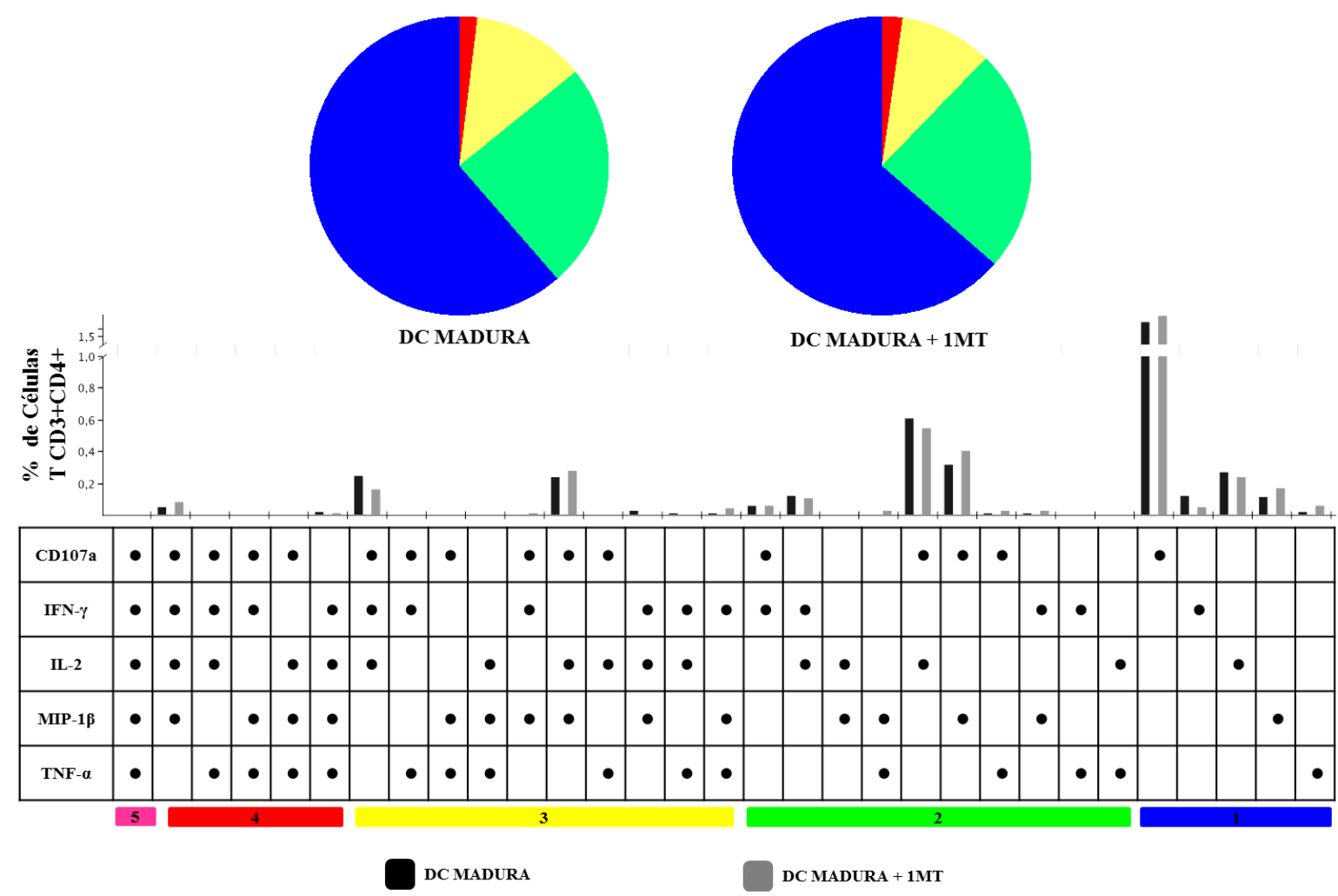

A capacidade das DCs maduras e maduras $+1 \mathrm{MT}$ em estimular linfócitos autólogos TCD4 ${ }^{+}$foi avaliada pela expressão individual e simultânea de moléculas de citotoxicidade (CD107a), citocinas pró-inflamatórias (IL-2, TNF- $\alpha$ e IFN- $\gamma$ ) e quimiocina (MIP-1 $\beta$ ). O diagrama de setores circulares representa a intensidade da resposta T celular obtida de acordo com o número de mediadores produzidos: 1 (azul), 2 (verde), 3 (amarelo), 4 (vermelho) e 5 (rosa). $\mathrm{O}$ gráfico de barras representa a proporção de células $\mathrm{TCD}^{+}{ }^{+}$responsáveis pela produção desses mediadores imunológicos, de forma combinada (atividade polifuncional) ou isolada (atividade monofuncional), em cada um dos estímulos utilizados. Os gráficos em barra representam a média de 5 experimentos realizados com amostras de indivíduos $\mathrm{HIV}^{+}$.

Assim como nas DCs maduras, é possível observar na figura 22 que o perfil de resposta encontrado após 24 de cocultivo é semelhante tanto no estímulo com DCs pulsadas, quanto no estímulo com essas mesmas DCs após tratamento com 1-MT. Foi observada indução de resposta monofuncional em cerca de $65 \%$ dos linfócitos analisados, o que acarreta uma resposta polifuncional em cerca de $35 \%$ das células TCD4 ${ }^{+}$autólogas. 
Vale ressaltar que a resposta polifuncional caracterizada pela produção simultânea de 2 marcadores imunológicos foi evidenciada principalmente na combinação entre CD107a e IL2, além desse mesmo carcador de citotoxicidade associado com a quimiocina MIP-1ß.

Figura 22 - Produção de mediadores imunológicos por linfócitos TCD4 ${ }^{+}$estimulados por 24 horas com DCs pulsadas e DCs pulsadas/1MT.

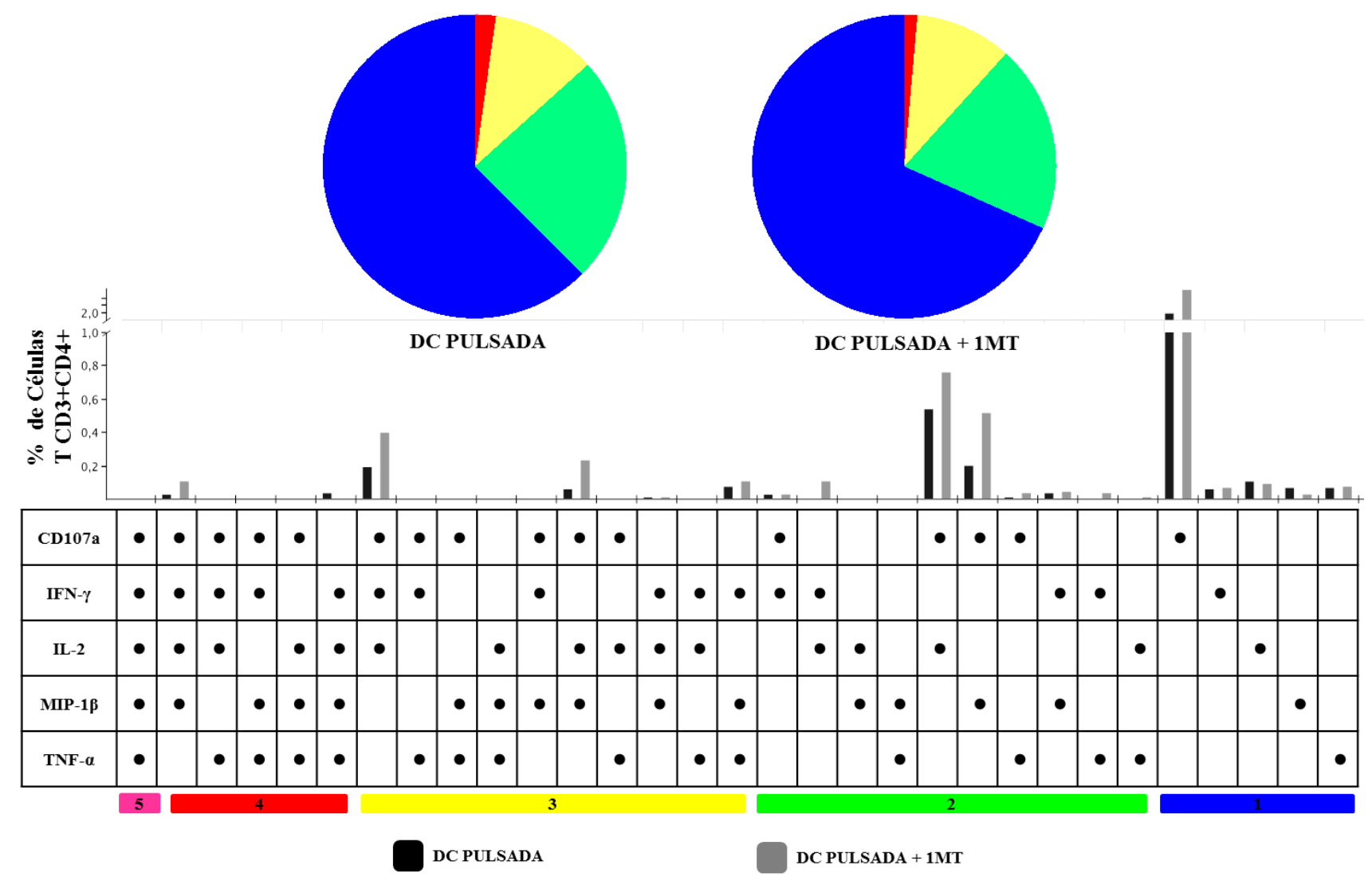

A capacidade das DCs pulsadas e pulsadas + 1MT em estimular linfócitos autólogos TCD4 ${ }^{+}$foi avaliada pela expressão individual e simultânea de moléculas de citotoxicidade (CD107a), citocinas pró-inflamatórias (IL-2, TNF- $\alpha$ e IFN- $\gamma$ ) e quimiocina (MIP-1 $\beta$ ). O diagrama de setores circulares representa a intensidade da resposta T celular obtida de acordo com o número de mediadores produzidos: 1 (azul), 2 (verde), 3 (amarelo), 4 (vermelho) e 5 (rosa). O gráfico de barras representa a proporção de células $\mathrm{TCD}^{+}{ }^{+}$responsáveis pela produção desses mediadores imunológicos, de forma combinada (atividade polifuncional) ou isolada (atividade monofuncional), em cada um dos estímulos utilizados. Os gráficos em barra representam a média de 5 experimentos realizados com amostras de indivíduos $\mathrm{HIV}^{+}$.

Em conjunto, nossos dados demonstram que em 24 horas cocultivo as DCs ativadas são capazes de induzir uma resposta polifuncional em linfócitos $\mathrm{TCD}^{+}$autólogos de maior 
intensidade do que as DCs imaturas. Além disso, o pulso com HIV quimicamente inativado não foi capaz de manter os níveis de resposta induzido pelas DCs imaturas. O tratamento com o bloqueador da enzima IDO não alterou o perfil de resposta encontrado tanto das DCs maduras, quanto nas DCs pulsadas.

\subsubsection{Atividade polifuncional de linfócitos $\mathrm{TCD}^{+}$autólogos estimulados por DCs em $96 \mathrm{~h}$ horas de cocultivo}

Todas as análises realizadas em 24 horas de cocultivo foram realizadas também após $96 \mathrm{~h}$ de cultura. Vale lembrar que, nesse ultimo tempo, foram analisados apenas 4 mediadores imunológicos (IL-2, TNF- $\alpha$, IFN- $\gamma$ e/ou MIP-1 $)$ ).

$\mathrm{Na}$ figura 23, é possível observar que a indução de polifuncionalidade se concentrou na combinação de dois mediadores apenas, sendo que as DCs ativadas foram capazes de estimular cerca de $23,6 \%$ dos linfócitos analisados, enquanto as DCs imaturas apenas $11 \%$. Apesar do perfil de resposta ser semelhante ao observado em 24 horas, é possível notar uma queda na intensidade da resposta induzida, já que as combinações de 3 e 4 mediadores foi praticamente inexistente nos estímulos utilizados.

Em relação à resposta polifuncional de maior intensidade observada nos três estímulos distintos utilizados, a combinação entre as citocinas IFN- $\gamma$ e IL-2 obteve maior relevância. A atividade monofuncional foi representada principalmente pelas citocinas IL-2 e TNF- $\alpha$. 
Figura 23 - Produção de mediadores imunológicos por linfócitos TCD4 ${ }^{+}$estimulados por 96 horas com DCs em diferentes estágios de ativação.

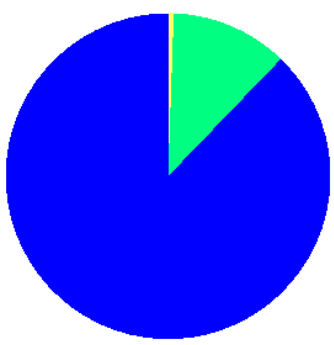

DC IMATURA

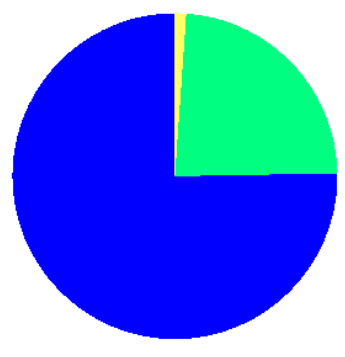

DC MADURA

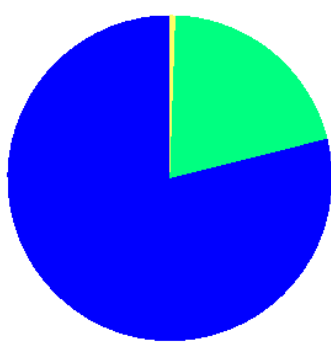

DC PULSADA
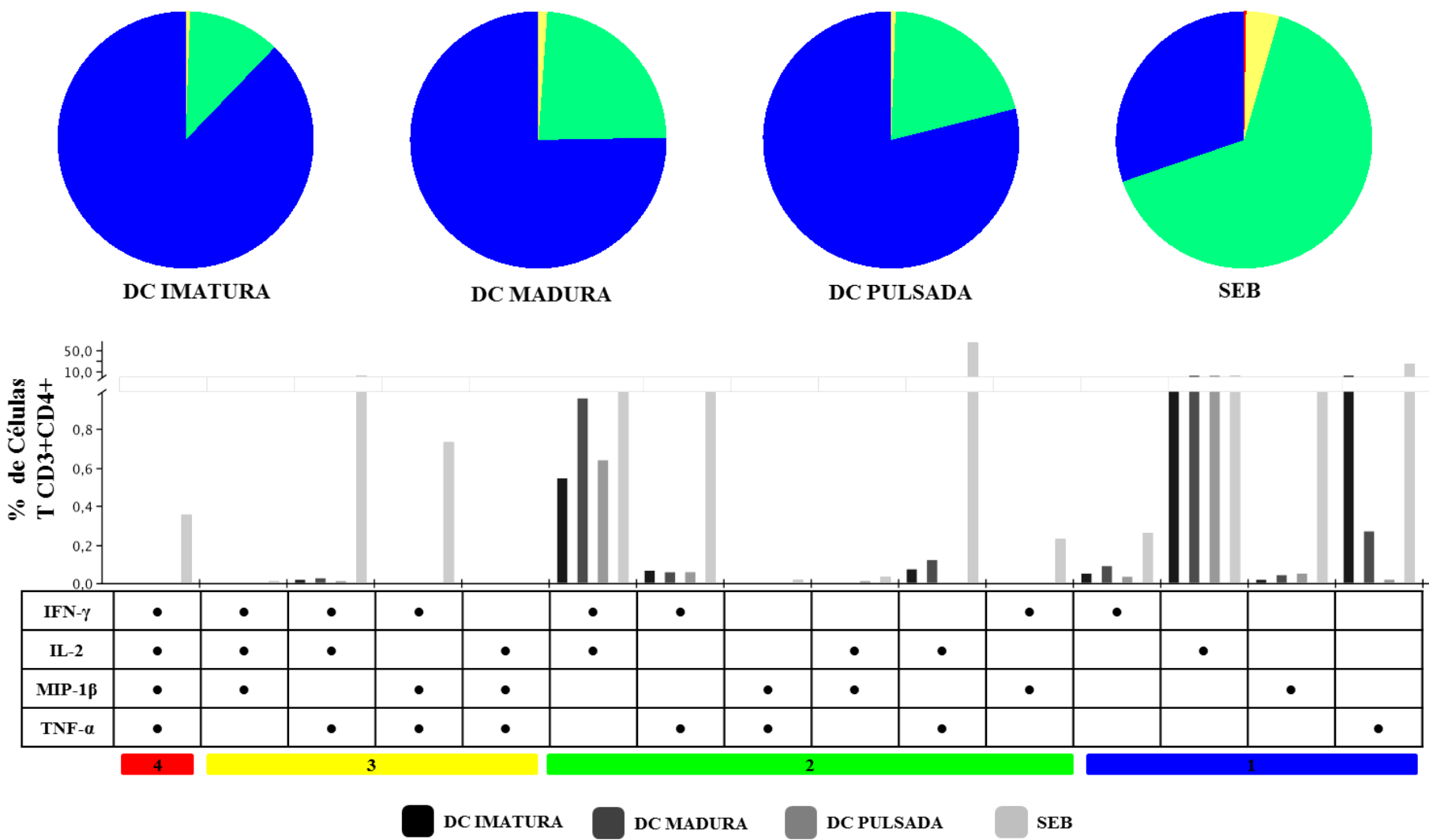

A capacidade das DCs (imaturas, maduras ou pulsadas) em estimular linfócitos autólogos TCD4 ${ }^{+}$foi avaliada pela expressão individual e simultânea de citocinas pró-inflamatórias (IL-2, TNF- $\alpha$ e IFN- $\gamma$ ) e quimiocina (MIP$1 \beta)$. O diagrama de setores circulares representa a intensidade da resposta $\mathrm{T}$ celular obtida de acordo com o número de mediadores produzidos: 1 (azul), 2 (verde), 3 (amarelo) e 4 (vermelho). O gráfico de barras representa a proporção de células $\mathrm{TCD}^{+}{ }^{+}$responsáveis pela produção desses mediadores imunológicos, de forma combinada (atividade polifuncional) ou isolada (atividade monofuncional), em cada um dos estímulos utilizados. Os gráficos em barra representam a média de 10 experimentos realizados com amostras de indivíduos $\mathrm{HIV}^{+}$.

Da mesma maneira do que ocorreu em 24 horas de cocultivo, a capacidade do pulso com HIV quimicamente inativado nas DCs imaturas em induzir alterações na resposta polifuncional encontrada também foi avaliada.

$\mathrm{Na}$ figura 24, observa-se que as DCs imaturas foram capazes de induzir resposta polifuncional em cerca de $34 \%$ das células analisadas, enquanto essas mesma células com pulso viral adicional induziram cerca de $24 \%$ de linfócitos autólogos a uma resposta polifuncional. Porém, se levarmos em consideração a resposta polifuncional de maior intensidade, produção simultânea de 4 mediadores imunológicos, observamos que DCs 
imaturas que receberam o pulso viral foram capazes de estimular 4 vezes mais células do que as DCs imaturas.

Figura 24 - Produção de mediadores imunológicos por linfócitos TCD4+ estimulados por 96 horas com DCs imaturas e DCs imaturas/virus.

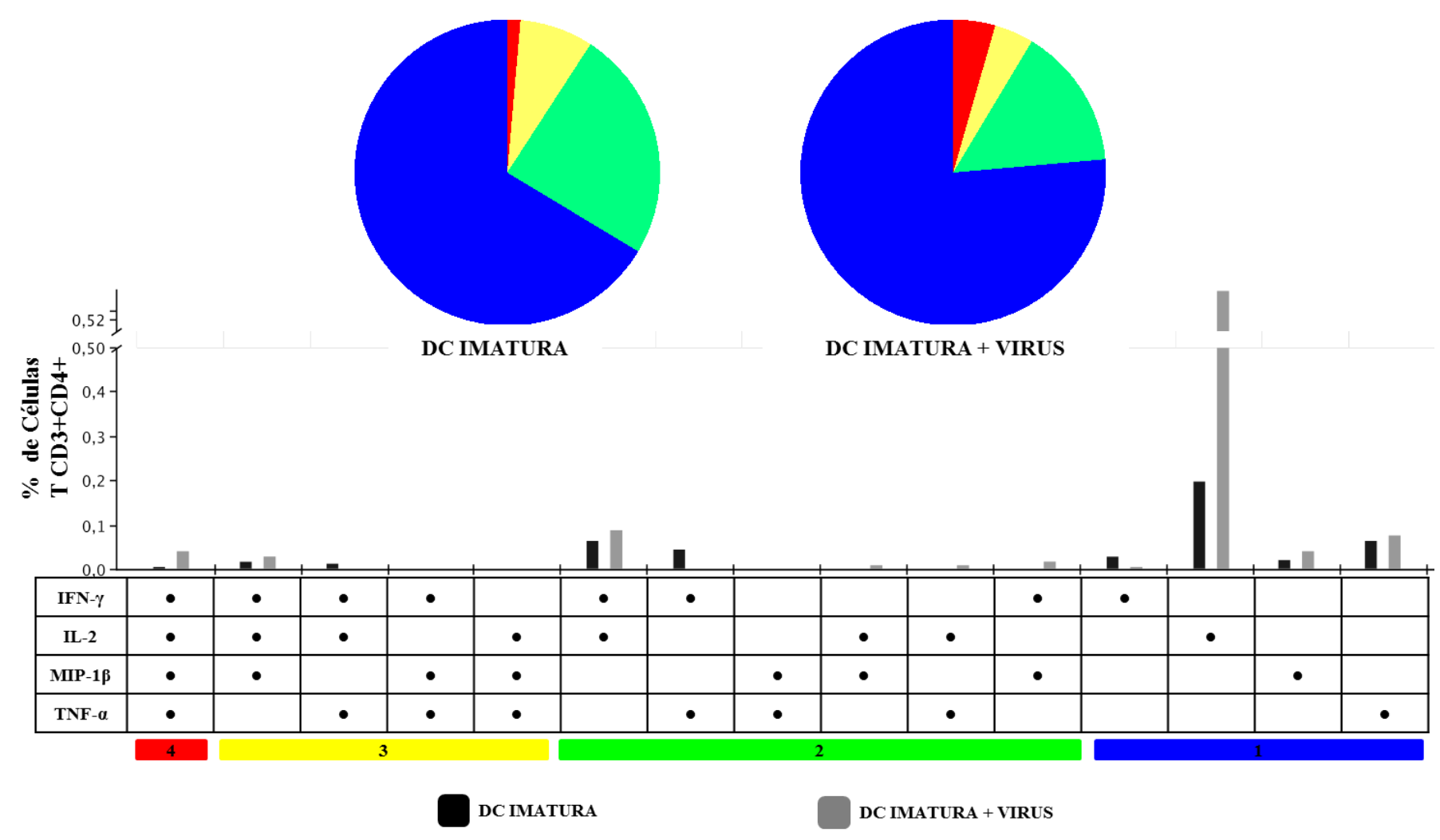

A capacidade das DCs imaturas e imaturas + vírus em estimular linfócitos autólogos TCD4 ${ }^{+}$foi avaliada pela expressão individual e simultânea de citocinas pró-inflamatórias (IL-2, TNF- $\alpha$ e IFN- $\gamma$ ) e quimiocina (MIP-1 $\beta$ ). O diagrama de setores circulares representa a intensidade da resposta $\mathrm{T}$ celular obtida de acordo com o número de mediadores produzidos: 1 (azul), 2 (verde), 3 (amarelo) e 4 (vermelho). O gráfico de barras representa a proporção de células $\mathrm{TCD}^{+}{ }^{+}$responsáveis pela produção desses mediadores imunológicos, de forma combinada (atividade polifuncional) ou isolada (atividade monofuncional), em cada um dos estímulos utilizados. Os gráficos em barra representam a média de 5 experimentos realizados com amostras de indivíduos HIV ${ }^{+}$.

Em seguida, foram analisados os ensaios realizados com o bloqueador de IDO.

$\mathrm{Na}$ figura 25, diferentemente do observado em 24 horas, o tratamento com 1-metiltriptofano nas DCs maduras apresentou uma resposta polifuncional discretamente elevada (40\% dos linfócitos observados) em comparação as DCs maduras na ausência desse tratamento (34\% dos linfócitos observados). Levando em consideração a resposta 
polifuncional de maior intensidade, 4 mediadores produzidos simultaneamente, observamos que o tratamento com bloqueador estimulou cerca de 1,2\% dos linfócitos, enquanto nas DCs sem esse tratamento esse estímulo foi de $0,7 \%$.

Figura 25 - Produção de mediadores imunológicos por linfócitos TCD4 ${ }^{+}$estimulados por 96 horas com DCs maduras e DCs maduras/1MT.

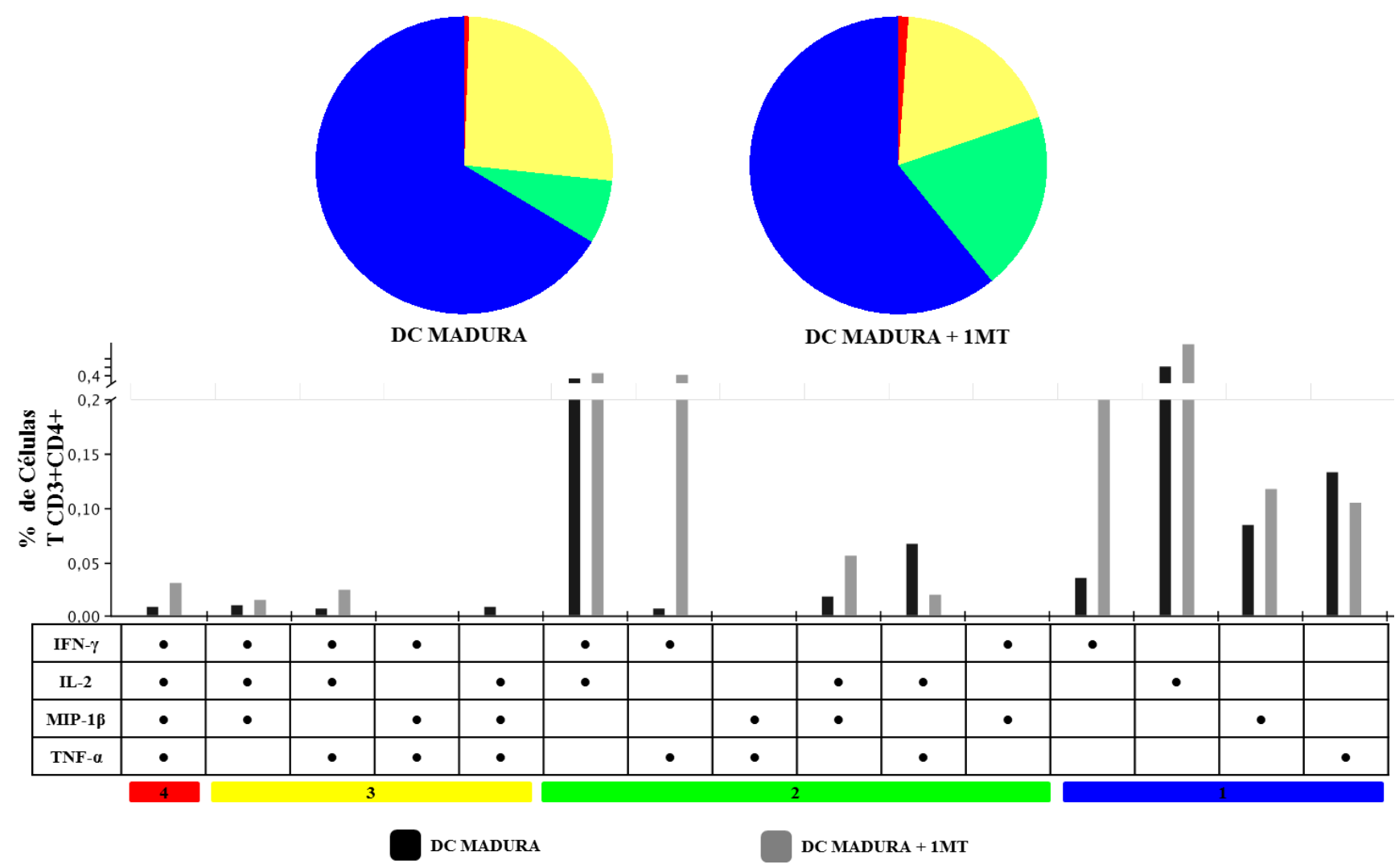

A capacidade das DCs maduras e maduras + 1MT em estimular linfócitos autólogos TCD4 ${ }^{+}$foi avaliada pela expressão individual e simultânea de citocinas pró-inflamatórias (IL-2, TNF- $\alpha$ e IFN- $\gamma$ ) e quimiocina (MIP-1 $\beta$ ). O diagrama de setores circulares representa a intensidade da resposta $\mathrm{T}$ celular obtida de acordo com o número de mediadores produzidos: 1 (azul), 2 (verde), 3 (amarelo) e 4 (vermelho). O gráfico de barras representa a proporção de células $\mathrm{TCD}^{+}{ }^{+}$responsáveis pela produção desses mediadores imunológicos, de forma combinada (atividade polifuncional) ou isolada (atividade monofuncional), em cada um dos estímulos utilizados. Os gráficos em barra representam a média de 5 experimentos realizados com amostras de indivíduos $\mathrm{HIV}^{+}$.

Com relação ao estímulo com DCs pulsadas, o aumento da polifuncionalidade dos linfócitos autólogos estimulados pelas DCs após tratamento com 1-metil-triptofano foi melhor evidenciado, como observado na figura 26. As DCs pulsadas estimularam resposta polifuncional em cerca de $28 \%$ das células, enquanto as DCs pulsadas com o bloqueador foram capazes de induzir essa mesma resposta em $44 \%$ das células. Esses dados são 
corroborados pelo aumento de aproximadamente 5 vezes na resposta polifuncional de maior intensidade no estímulo com DCs pulsadas na presença do bloqueador quando comparadas a essa mesma população celular sem o tratamento com 1-metil-triptofano.

Figura 26 - Produção de mediadores imunológicos por linfócitos TCD4 ${ }^{+}$estimulados por 96 horas com DCs pulsadas e DCs pulsadas/1MT.

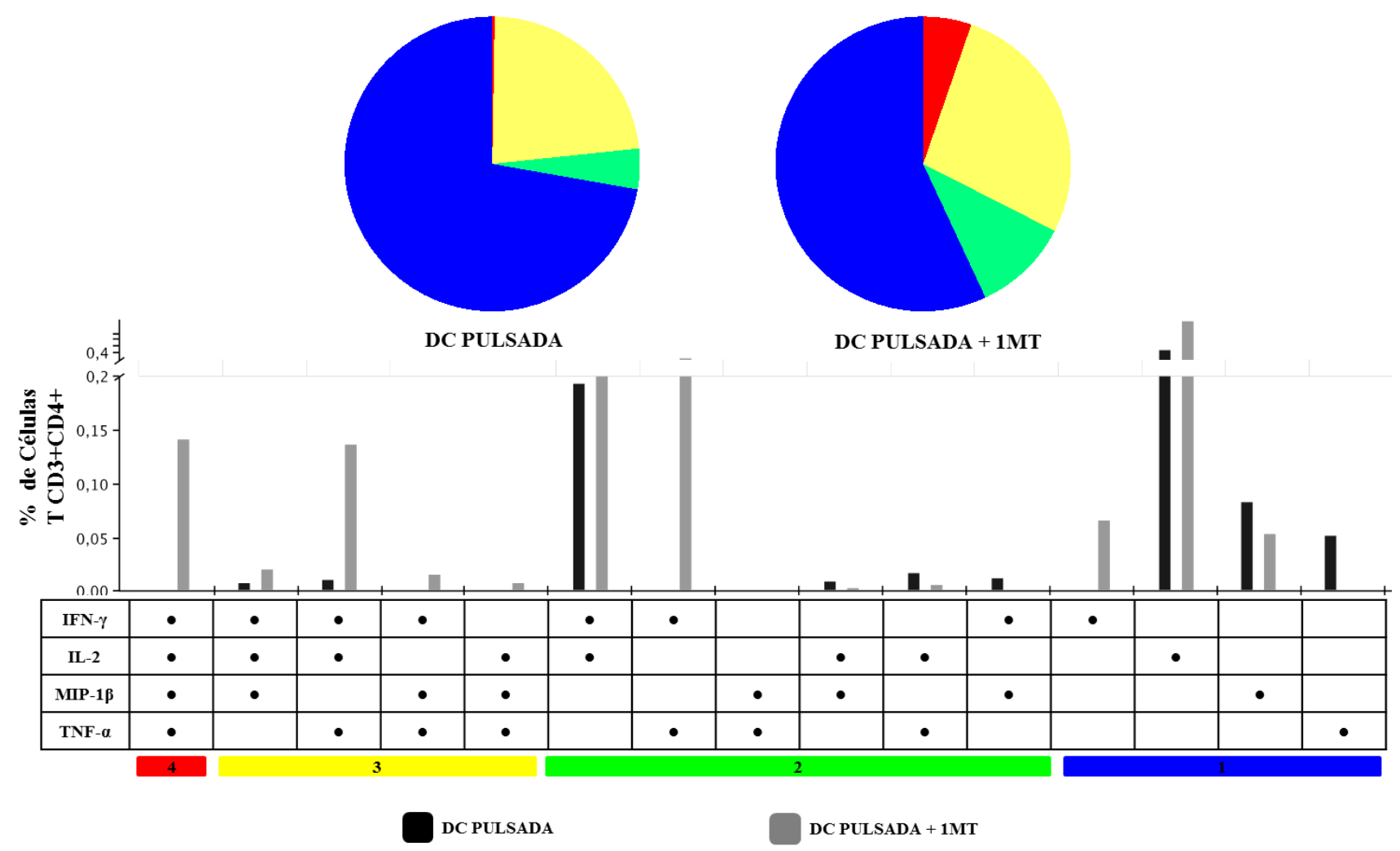

A capacidade das DCs pulsadas e pulsadas + 1MT em estimular linfócitos autólogos TCD4 ${ }^{+}$foi avaliada pela expressão individual e simultânea de citocinas pró-inflamatórias (IL-2, TNF- $\alpha$ e IFN- $\gamma$ ) e quimiocina (MIP-1 $\beta$ ). $\mathrm{O}$ diagrama de setores circulares representa a intensidade da resposta $\mathrm{T}$ celular obtida de acordo com o número de mediadores produzidos: 1 (azul), 2 (verde), 3 (amarelo) e 4 (vermelho). O gráfico de barras representa a proporção de células $\mathrm{TCD}^{+}$responsáveis pela produção desses mediadores imunológicos, de forma combinada (atividade polifuncional) ou isolada (atividade monofuncional), em cada um dos estímulos utilizados. Os gráficos em barra representam a média de 5 experimentos realizados com amostras de indivíduos $\mathrm{HIV}^{+}$.

Em conjunto, esses dados demonstram que em 96 horas de cocultivo as DCs ativadas são capazes de induzir uma resposta polifuncional em linfócitos $\mathrm{TCD}^{+}$autólogos de maior intensidade do que as DCs imaturas, embora a intensidade dessa resposta tenha sido inferior a que foi encontrada em 24 horas. Além disso, o pulso com HIV quimicamente inativado foi capaz de induzir uma resposta polifuncional potente em níveis mais elevados do que os observados no estímulo com DCs imaturas. Diferentemente do observado em $24 \mathrm{~h}$ de 
estímulo, em 96h o tratamento com o bloqueador da enzima IDO elevou a intensidade da resposta polifuncional induzida pelas DCs ativadas, principalmente nas DCs pulsadas.

\subsubsection{Atividade polifuncional de linfócitos TCD8 ${ }^{+}$autólogos estimulados por DCs em 24 horas de cocultivo}

As mesmas análises realizadas com linfócitos $\mathrm{TCD}^{+}$foram reproduzidas com linfócitos $\mathrm{TCD}^{+}$.

Em relação ao cocultivo por 24 horas com DCs em diferentes estágios de maturação, foi possível notar que, diferentemente do observado nos linfócitos $\mathrm{TCD}^{+}$, as $\mathrm{DCs}$ imaturas foram capazes de induzir resposta polifuncional em cerca de $78 \%$ das células analisadas, enquanto as DCs maduras e pulsadas induziram essa resposta em apenas $60 \%$ dos linfócitos. Os resultados estão representados na figura 27.

É importante ressaltar que a intensidade da resposta polifuncional induzida pelas DCs em linfócitos $\mathrm{TCD}^{+}$se restringiu a combinação de 3 e 2 mediadores imunológicos, já que a resposta mais potente de 5 e 4 mediadores produzidos simultaneamente foi praticamente inexistente quando induzido pelas DCs nos três estágios de diferenciação.

O controle positivo do ensaio, constituído pelo estímulo com SEB nas ultimas 6 horas de cocultivo, conseguiu estimular resposta polifuncional em $70 \%$ dos linfócitos TCD8+ analisados. A maior intensidade de polifuncionalidade, representada pela produção de 5 mediadores imunológicos simultaneamente, foi observada em $0,45 \%$ das células analisadas, enquanto a produção simultânea de 4 mediadores foi observada em $21 \%$ das células.

Esses dados sugerem que as células $\mathrm{TCD}^{+}$analisadas possuem capacidade de produzir uma resposta polifuncional potente, o que depende principalmente do tipo de estímulo utilizado. 
Figura 27 - Produção de mediadores imunológicos por linfócitos TCD8 ${ }^{+}$estimulados por 24 horas com DCs em diferentes estágios de ativação.
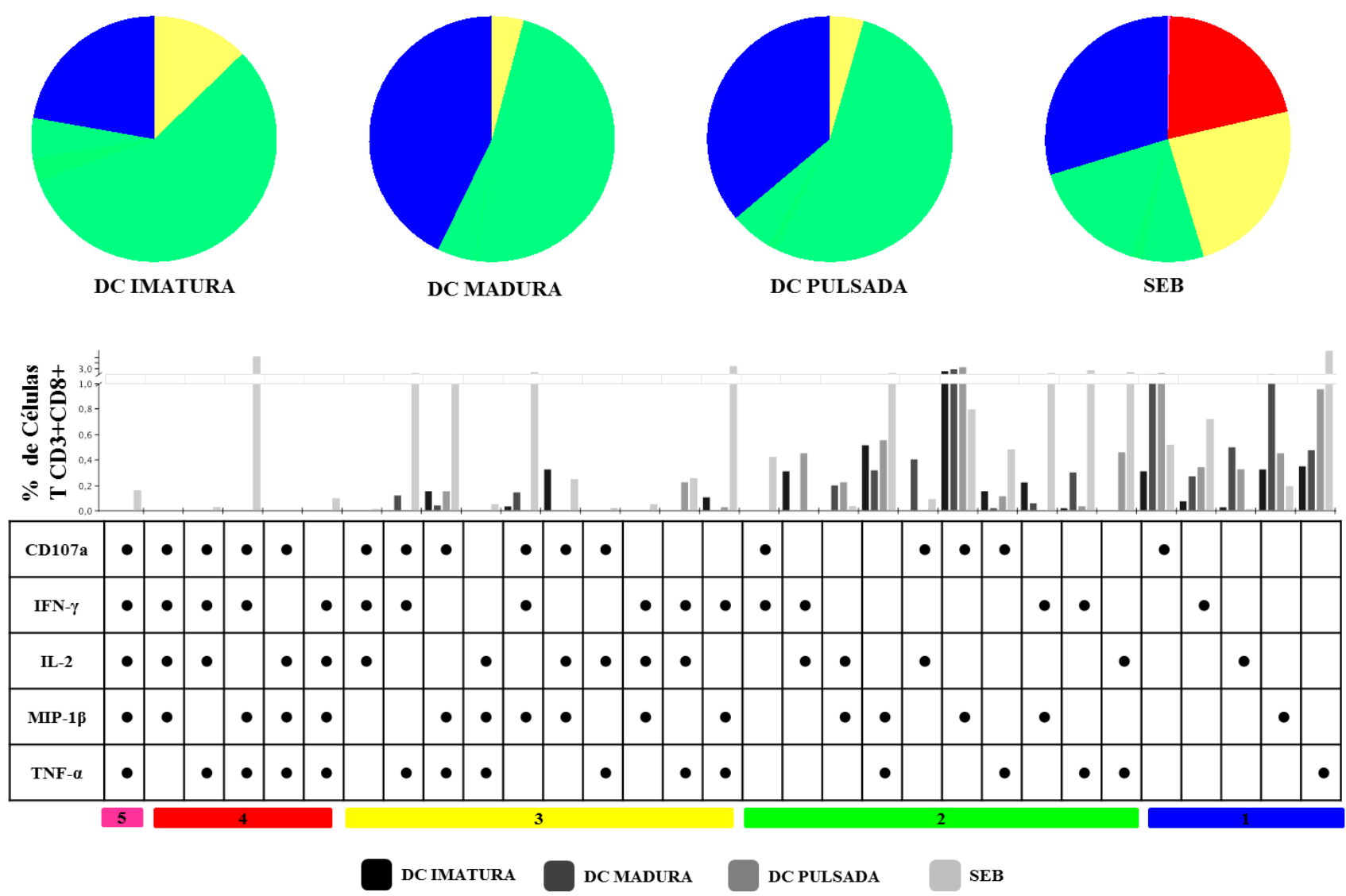

A capacidade das DCs (imaturas, maduras ou pulsadas) em estimular linfócitos autólogos $\mathrm{TCD} 8^{+}$foi avaliada pela expressão individual e simultânea de moléculas de citotoxicidade (CD107a), citocinas pró-inflamatórias (IL-2, TNF- $\alpha$ e IFN- $\gamma$ ) e quimiocina (MIP-1 $\beta$ ). O diagrama de setores circulares representa a intensidade da resposta $\mathrm{T}$ celular obtida de acordo com o número de mediadores produzidos: 1 (azul), 2 (verde), 3 (amarelo), 4 (vermelho) e 5 (rosa). O gráfico de barras representa a proporção de células TCD8 ${ }^{+}$responsáveis pela produção desses mediadores imunológicos, de forma combinada (atividade polifuncional) ou isolada (atividade monofuncional), em cada um dos estímulos utilizados. Os gráficos em barra representam a média de 10 experimentos realizados com amostras de indivíduos $\mathrm{HIV}^{+}$.

Com relação ao pulso com HIV quimicamente inativado, na figura 28 é possível observar que as DCs imaturas induziram uma resposta polifuncional em $43 \%$ dos linfócitos analisados, enquanto a porção de DCs imaturas que recebeu o pulso viral induziu essa mesma resposta em apenas $18 \%$ dos linfócitos. Apesar disso, é importante destacar que o pulso com o HIV inativado induziu uma resposta polifuncional potente, representada pela produção simultânea de 4 mediadores imunológicos (IFN- $\gamma$, IL-2, MIP-1 $\beta$ e TNF- $\alpha$ ) em cerca de $2 \%$ das células analisadas, resposta esta ausente no estímulo com DCs imaturas sem o pulso viral. 
Figura 28 - Produção de mediadores imunológicos por linfócitos TCD8 ${ }^{+}$estimulados por 24 horas com DCs imaturas e DCs imaturas/virus.
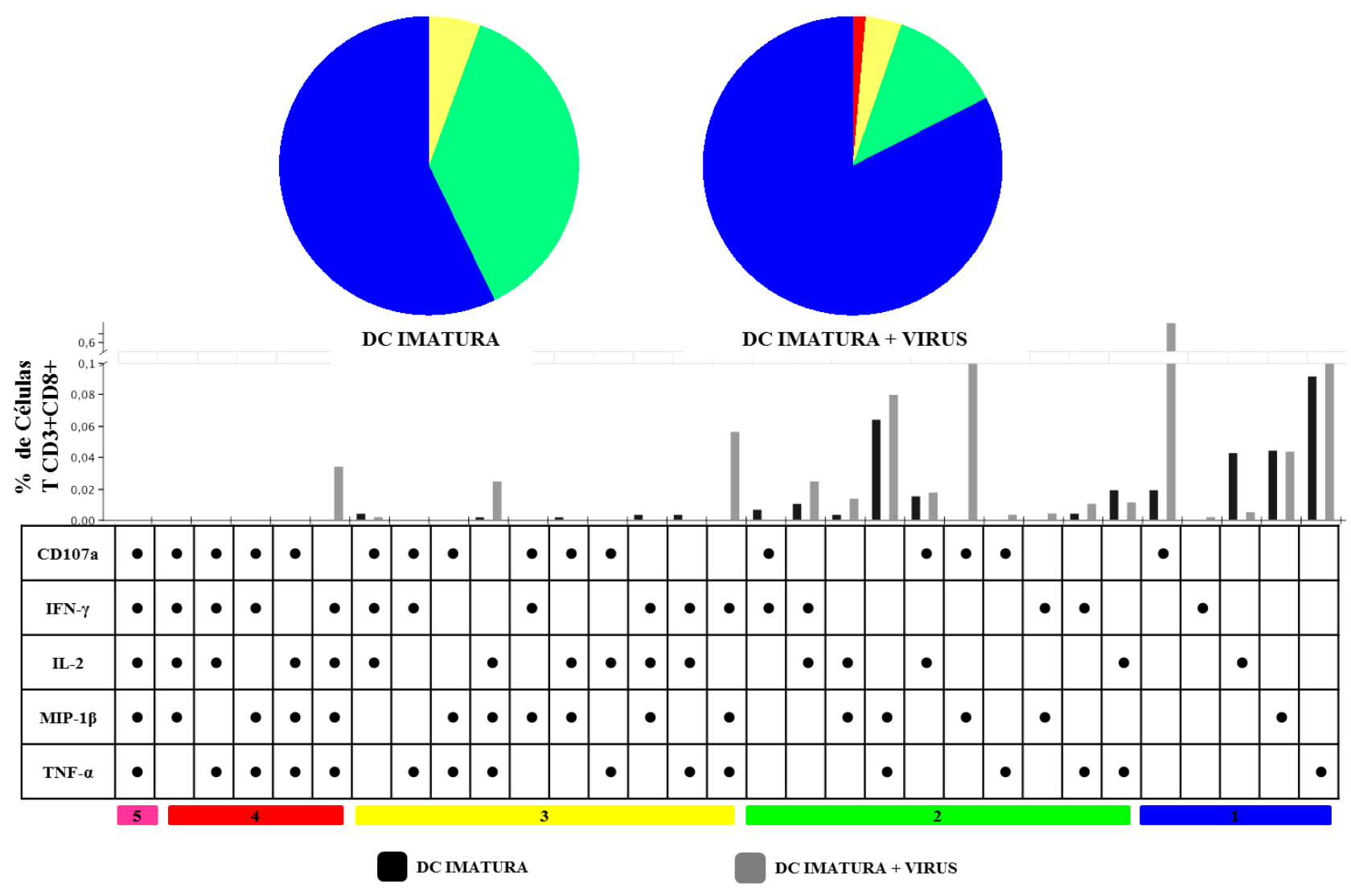

A capacidade das DCs imaturas e imaturas + virus em estimular linfócitos autólogos TCD $8^{+}$foi avaliada pela expressão individual e simultânea de moléculas de citotoxicidade (CD107a), citocinas pró-inflamatórias (IL-2, TNF- $\alpha$ e IFN- $\gamma$ ) e quimiocina (MIP-1 $\beta$ ). O diagrama de setores circulares representa a intensidade da resposta $\mathrm{T}$ celular obtida de acordo com o número de mediadores produzidos: 1 (azul), 2 (verde), 3 (amarelo), 4 (vermelho) e 5 (rosa). O gráfico de barras representa a proporção de células $\mathrm{TCD} 8^{+}$responsáveis pela produção desses mediadores imunológicos, de forma combinada (atividade polifuncional) ou isolada (atividade monofuncional), em cada um dos estímulos utilizados. Os gráficos em barra representam a média de 5 experimentos realizados com amostras de indivíduos $\mathrm{HIV}^{+}$.

A influência do bloqueio da enzima IDO no perfil de resposta induzido pelas DCs também foi analisado em células $\mathrm{TCD}^{+}$. Na figura 29, é possível observar que, similarmente ao observado nas células TCD4 ${ }^{+}$, as DCs maduras na presença ou não do bloqueador da enzima IDO apresentam um perfil semelhante de indução de resposta polifuncional em linfócitos $\mathrm{TCD}^{+}$. Observamos apenas um discreto aumento dessa resposta no estímulo com DCs 
maduras tratadas com 1-metil-triptofano (30\% das células analisadas) quando comparadas ao estímulo com DCs maduras na ausência desse tratamento (25\% das células analisadas).

Figura 29 - Produção de mediadores imunológicos por linfócitos TCD8 ${ }^{+}$estimulados por 24 horas com DCs maduras e DCs maduras/1MT.

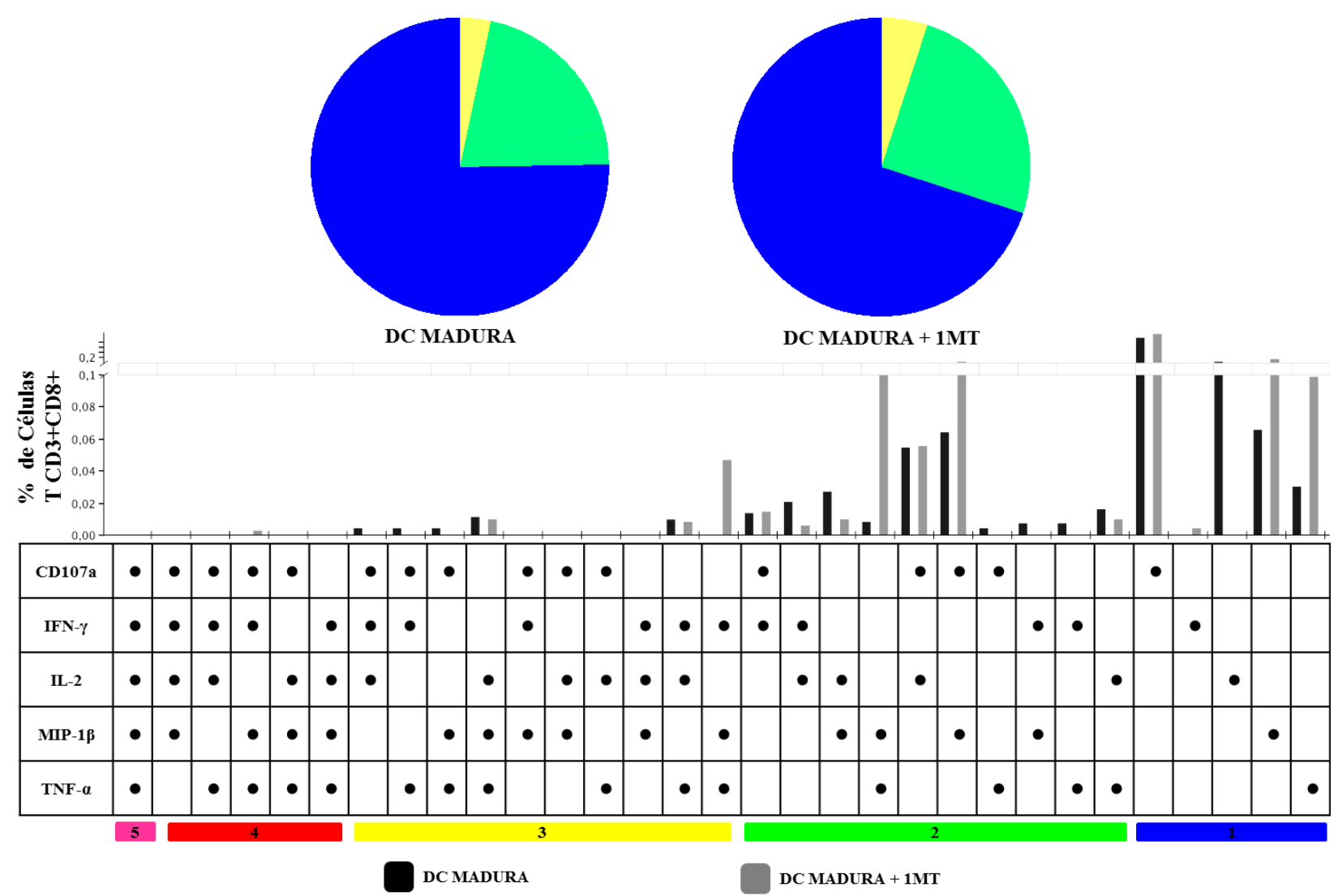

A capacidade das DCs maduras e maduras + 1MT em estimular linfócitos autólogos TCD8 ${ }^{+}$foi avaliada pela expressão individual e simultânea de moléculas de citotoxicidade (CD107a), citocinas pró-inflamatórias (IL-2, TNF- $\alpha$ e IFN- $\gamma$ ) e quimiocina (MIP-1 $\beta$ ). O diagrama de setores circulares representa a intensidade da resposta T celular obtida de acordo com o número de mediadores produzidos: 1 (azul), 2 (verde), 3 (amarelo), 4 (vermelho) e 5 (rosa). O gráfico de barras representa a proporção de células $\mathrm{TCD}^{+}$responsáveis pela produção desses mediadores imunológicos, de forma combinada (atividade polifuncional) ou isolada (atividade monofuncional), em cada um dos estímulos utilizados. Os gráficos em barra representam a média de 5 experimentos realizados com amostras de indivíduos $\mathrm{HIV}^{+}$.

Por sua vez, as DCs pulsadas tratadas com 1-metil-triptofano não foram capazes de estimular os mesmo níveis de resposta polifuncional (cerca de 13\% dos linfócitos analisados), quando comparadas as DCs pulsadas sem esse tratamento (cerca de 30\% dos linfócitos analisadas), em células TCD ${ }^{+}$autólogas. Esses resultados estão representados na figura 30. 
Figura 30 - Produção de mediadores imunológicos por linfócitos TCD8 ${ }^{+}$estimulados por 24 horas com DCs pulsadas e DCs pulsadas/1MT.

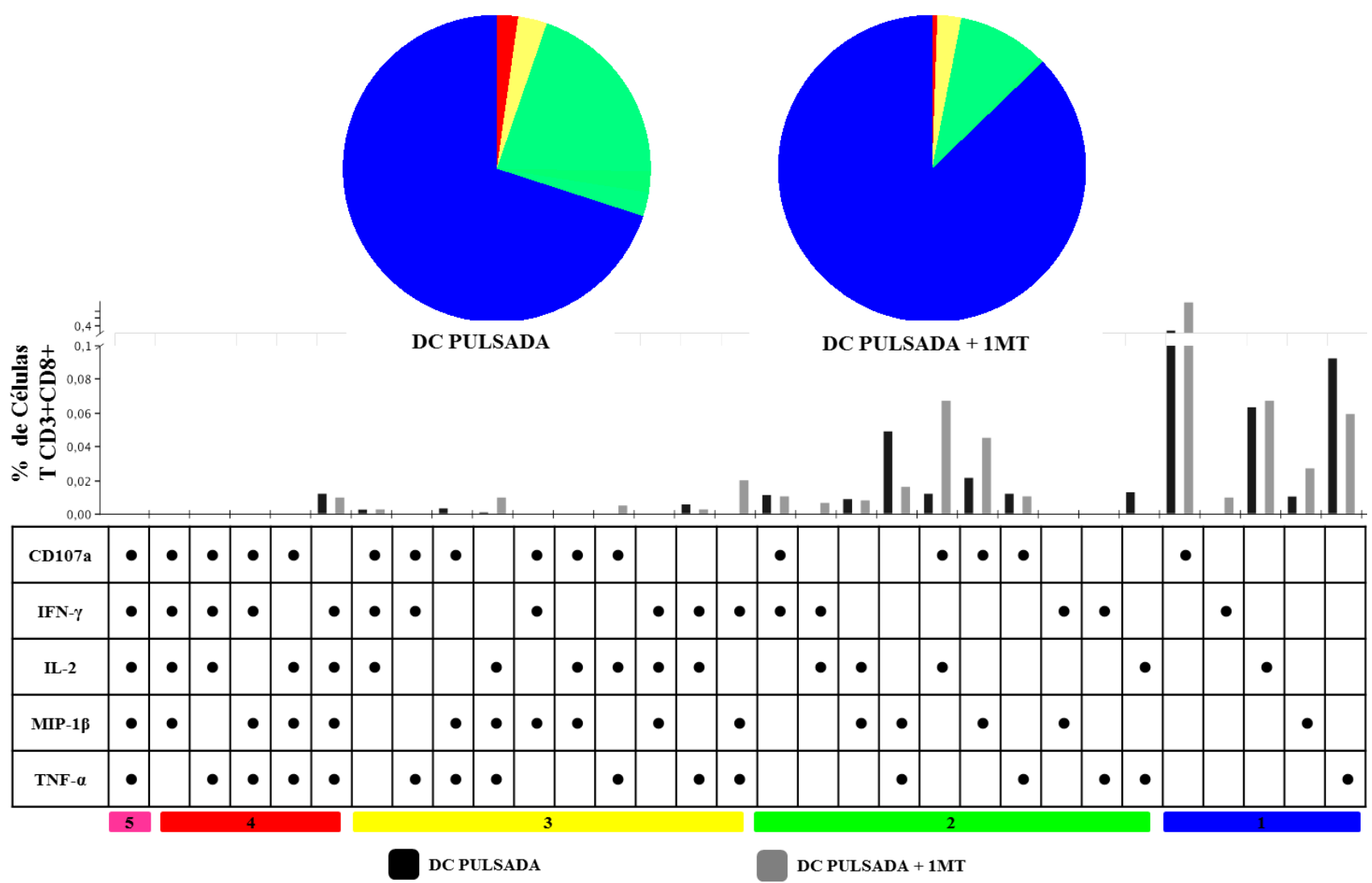

A capacidade das DCs pulsadas e pulsadas + 1MT em estimular linfócitos autólogos TCD8 ${ }^{+}$foi avaliada pela expressão individual e simultânea de moléculas de citotoxicidade (CD107a), citocinas pró-inflamatórias (IL-2, TNF- $\alpha$ e IFN- $\gamma$ ) e quimiocina (MIP-1 $\beta$ ). O diagrama de setores circulares representa a intensidade da resposta T celular obtida de acordo com o número de mediadores produzidos: 1 (azul), 2 (verde), 3 (amarelo), 4 (vermelho) e 5 (rosa). O gráfico de barras representa a proporção de células $\mathrm{TCD}^{+}$responsáveis pela produção desses mediadores imunológicos, de forma combinada (atividade polifuncional) ou isolada (atividade monofuncional), em cada um dos estímulos utilizados. Os gráficos em barra representam a média de 5 experimentos realizados com amostras de indivíduos $\mathrm{HIV}^{+}$.

Juntos, esses resultados indicam que, em 24 horas de cocultivo, DCs imaturas induzem uma resposta polifuncional em uma porcentagem maior de linfócitos $\mathrm{TCD}^{+}$autólogos quando comparadas as DCs ativadas, embora exista uma diminuição da potencialidade dessa resposta comparada àquela induzida em linfócitos $\mathrm{TCD}^{+}$no mesmo tempo de cocultivo. $\mathrm{O}$ pulso com HIV quimicamente inativado em DCs imaturas induziu resposta polifuncional em uma porcentagem menor de linfócitos $\mathrm{TCD}^{+}$quando comparadas as DCs imaturas sem o pulso viral, embora tenha sido observada uma resposta mais potente na presença do virus. $\mathrm{O}$ 
bloqueio da enzima IDO revelou um discreto aumento na resposta polifuncional induzida por DCs maduras, porém nas DCs pulsadas o tratamento com 1-metil-triptofano reduziu a porcentagem de linfócitos $\mathrm{TCD} 8^{+}$capazes de produzir uma resposta polifuncional.

\subsubsection{Atividade polifuncional de linfócitos $T C D 8^{+}$autólogos estimulados por DCs em $96 \mathrm{~h}$ horas de cocultivo}

Em seguida realizamos a análise da população $\mathrm{TCD}^{+}$estimulada por DCs imaturas, maduras ou pulsadas, além do controle positivo, em 96 horas de cocultivo.

$\mathrm{Na}$ figura 31 é possível observar que as DCs ativadas foram capazes de induzir uma resposta polifuncional em uma porcentagem maior de linfócitos $\mathrm{TCD}^{+}$quando comparadas as DCs imaturas. Enquanto a porção de DCs imaturas estimulou cerca de $20 \%$ dos linfócitos a esse tipo de resposta, as DCs maduras estimularam 56\% e as DCs pulsadas 30\% das células $\mathrm{TCD}^{+}$.

Vale lembrar que as DCs maduras apresentaram o melhor perfil de indução de polifuncionalidade, uma vez que estimularam cerca de $6 \%$ de resposta linfocitária com combinação de 4 mediadores, 32\% com combinação de 3 mediadores e 17\% com 2 mediadores produzidos simultaneamente.

As DCs pulsadas apresentaram capacidade de estímulo de resposta linfocitária potente, combinando 4 mediadores imunológicos, similar aquela encontrada nas DCs maduras, cerca de $6 \%$ dos linfócitos autólogos estimulados, embora a combinação entre 3 e 2 mediadores não tenha atingido os mesmos níveis. 
Figura 31 - Produção de mediadores imunológicos por linfócitos TCD8 ${ }^{+}$estimulados por 96 horas com DCs em diferentes estágios de ativação.

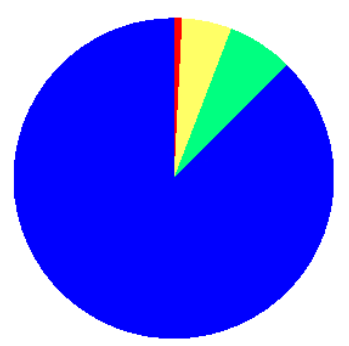

DC IMATURA

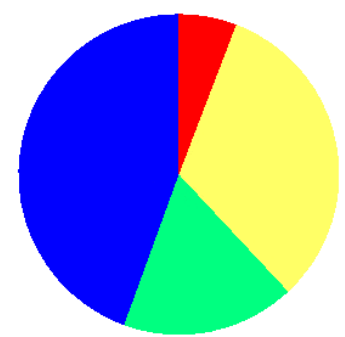

DC MADURA

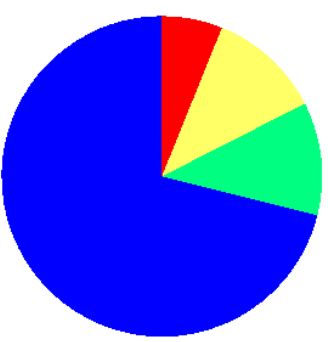

DC PULSADA

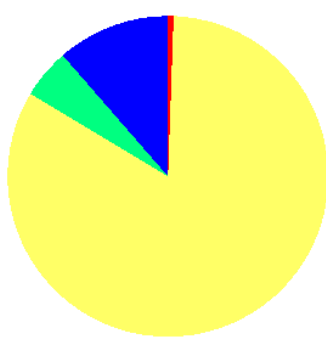

SEB

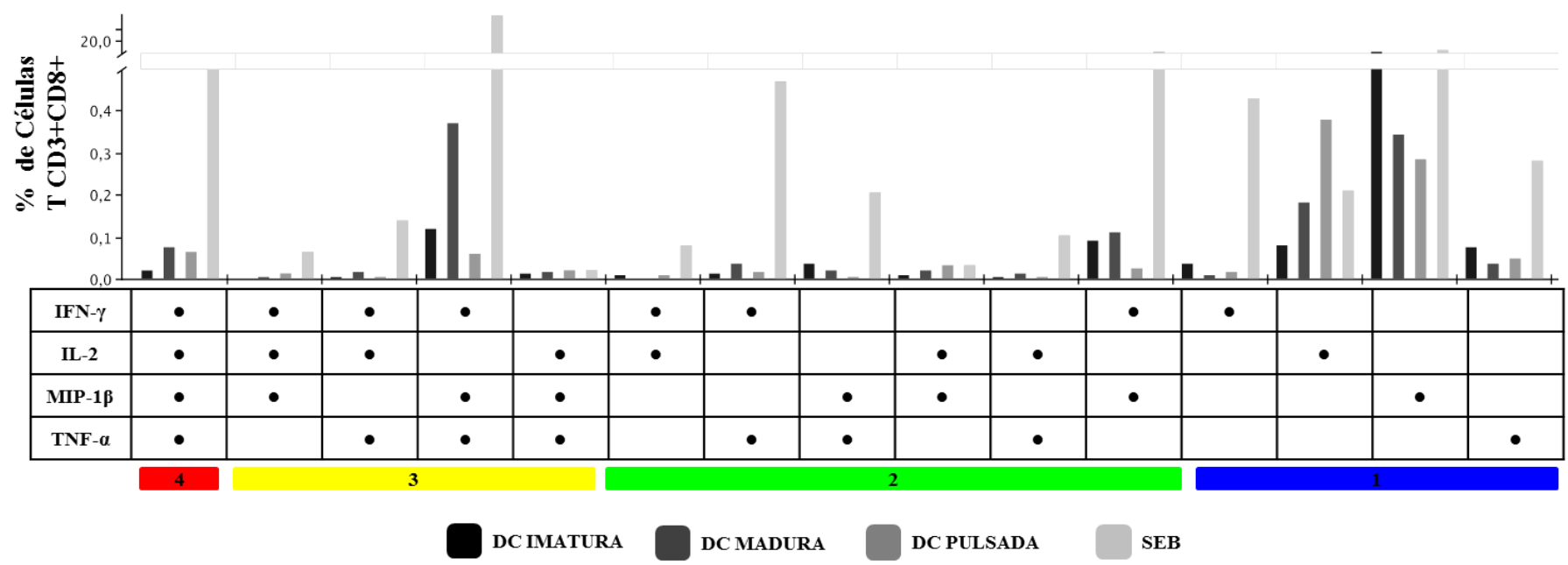

A capacidade das DCs (imaturas, maduras ou pulsadas) em estimular linfócitos autólogos TCD8 ${ }^{+}$foi avaliada pela expressão individual e simultânea de citocinas pró-inflamatórias (IL-2, TNF- $\alpha$ e IFN- $\gamma$ ) e quimiocina (MIP1ß). O diagrama de setores circulares representa a intensidade da resposta $\mathrm{T}$ celular obtida de acordo com o número de mediadores produzidos: 1 (azul), 2 (verde), 3 (amarelo) e 4 (vermelho). O gráfico de barras representa a proporção de células $\mathrm{TCD} 8^{+}$responsáveis pela produção desses mediadores imunológicos, de forma combinada (atividade polifuncional) ou isolada (atividade monofuncional), em cada um dos estímulos utilizados. Os gráficos em barra representam a média de 10 experimentos realizados com amostras de indivíduos $\mathrm{HIV}^{+}$.

O pulso com HIV quimicamente inativado não foi capaz de induzir alterações no perfil de resposta induzido pelas DCs imaturas após 96 horas de cocultivo com linfócitos TCD8+ autólogos. Os resultados estão representados na figura 31.

Ambos os estímulos foram capazes de induzir resposta polifuncional em cerca de $43 \%$ das células analisadas, com ênfase para a resposta mais potente, combinando 4 mediadores imunológicos, observada em cerca de $4 \%$ dos linfócitos. 
Figura 32 - Produção de mediadores imunológicos por linfócitos $\mathrm{TCD}^{+}$estimulados por 96 horas com DCs imaturas e DCs imaturas/virus.

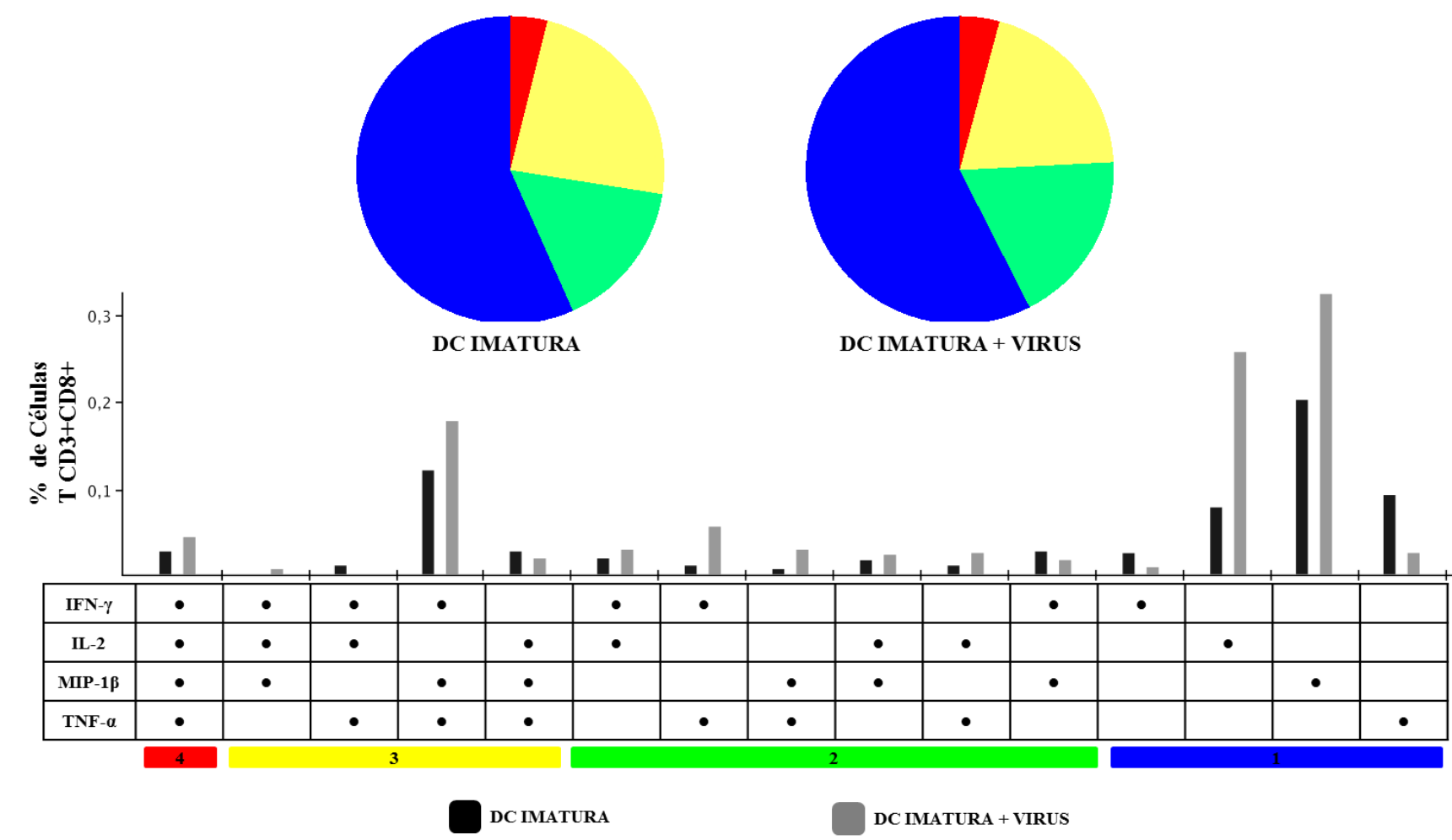

A capacidade das DCs imaturas e imaturas + virus em estimular linfócitos autólogos $\mathrm{TCD}^{+}$foi avaliada pela expressão individual e simultânea de citocinas pró-inflamatórias (IL-2, TNF- $\alpha$ e IFN- $\gamma$ ) e quimiocina (MIP-1 $\beta$ ). $\mathrm{O}$ diagrama de setores circulares representa a intensidade da resposta $\mathrm{T}$ celular obtida de acordo com o número de mediadores produzidos: 1 (azul), 2 (verde), 3 (amarelo) e 4 (vermelho). O gráfico de barras representa a proporção de células $\mathrm{TCD}^{+}$responsáveis pela produção desses mediadores imunológicos, de forma combinada (atividade polifuncional) ou isolada (atividade monofuncional), em cada um dos estímulos utilizados. Os gráficos em barra representam a média de 5 experimentos realizados com amostras de indivíduos $\mathrm{HIV}^{+}$.

Com relação ao bloqueio da enzima IDO, as DCs maduras tratadas ou não com 1-metiltriptofano apresentaram uma capacidade similar de indução de resposta polifuncional em linfócitos $\mathrm{TCD}^{+}$. Os resultados estão representados na figura 33.

Ambos os estímulos foram capazes de induzir resposta polifuncional em cerca de $35 \%$ dos linfócitos analisados, com ênfase para a resposta de maior intensidade, com produção simultânea de 4 mediadores imunológicos que ocorreu em cerca de 3\% das células. 
Figura 33 - Produção de mediadores imunológicos por linfócitos $\mathrm{TCD}^{+}$estimulados por 96 horas com DCs maduras e DCs maduras/1MT.

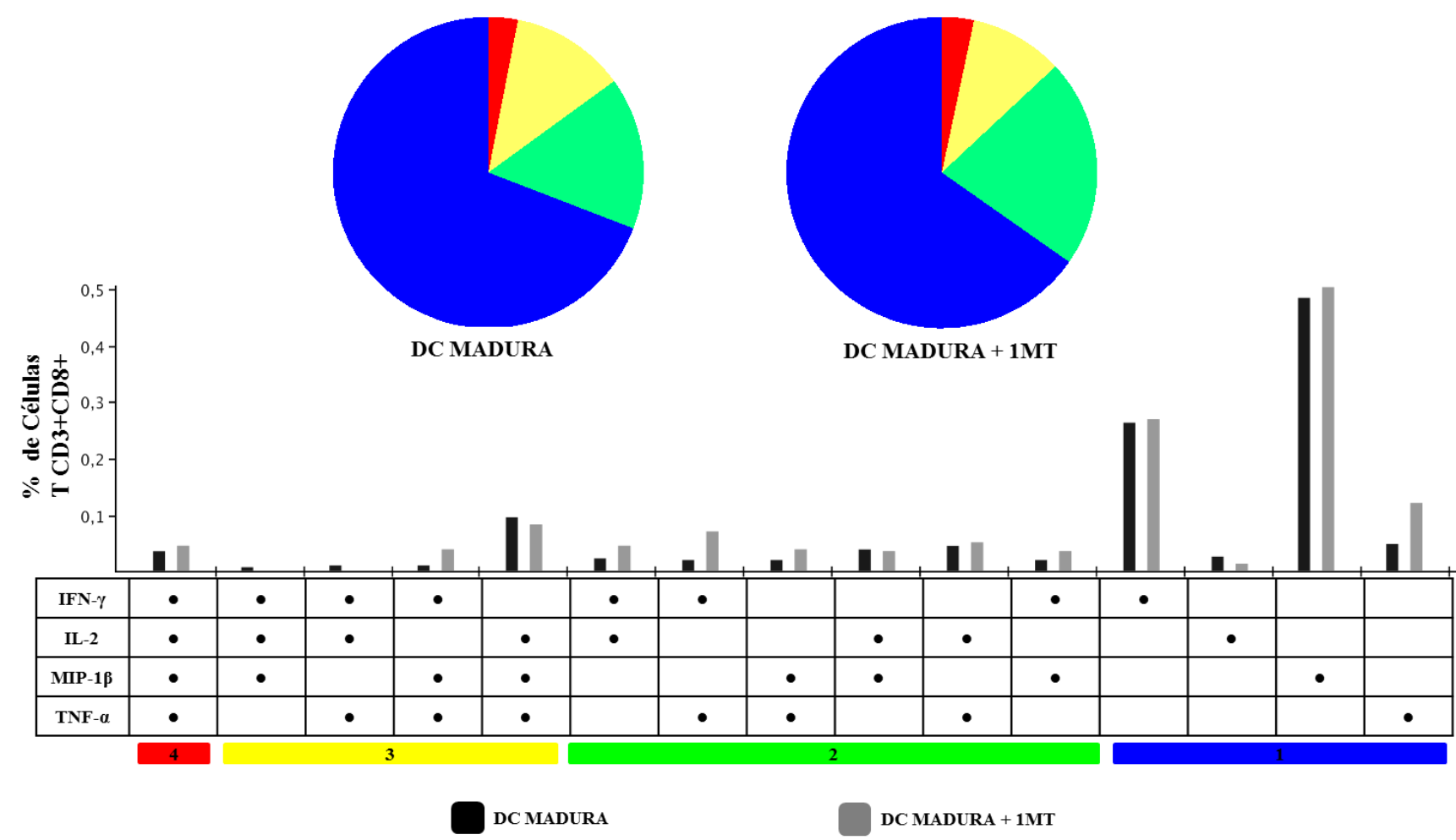

A capacidade das DCs maduras e maduras $+1 \mathrm{MT}$ em estimular linfócitos autólogos TCD ${ }^{+}$foi avaliada pela expressão individual e simultânea de citocinas pró-inflamatórias (IL-2, TNF- $\alpha$ e IFN- $\gamma$ ) e quimiocina (MIP-1 $\beta$ ). $\mathrm{O}$ diagrama de setores circulares representa a intensidade da resposta $\mathrm{T}$ celular obtida de acordo com o número de mediadores produzidos: 1 (azul), 2 (verde), 3 (amarelo) e 4 (vermelho). O gráfico de barras representa a proporção de células $\mathrm{TCD}^{+}$responsáveis pela produção desses mediadores imunológicos, de forma combinada (atividade polifuncional) ou isolada (atividade monofuncional), em cada um dos estímulos utilizados. Os gráficos em barra representam a média de 5 experimentos realizados com amostras de indivíduos HIV ${ }^{+}$.

As DCs pulsadas, tratadas com o bloqueador da enzima IDO, foram capazes de estimular cerca de $47 \%$ dos linfócitos $\mathrm{TCD}^{+}$a produzir uma resposta polifuncional, ou seja, produção simultânea de dois ou mais mediadores. Já as DCs pulsadas que não foram tratadas com 1metil-triptofano induziram essa mesma resposta em $40 \%$ dos linfócitos. Porém se considerarmos a resposta de maior intensidade, produção simultânea de 4 mediadores, o uso do bloqueador permitiu a indução de resposta potente em apenas 3\% doas células analisadas, enquanto a ausência desse tratamento permitiu essa mesma resposta em $9 \%$ das células. Os resultados estão representados na figura 34. 
Figura 34 - Produção de mediadores imunológicos por linfócitos TCD8 ${ }^{+}$estimulados por 96 horas com DCs maduras e DCs maduras/1MT.

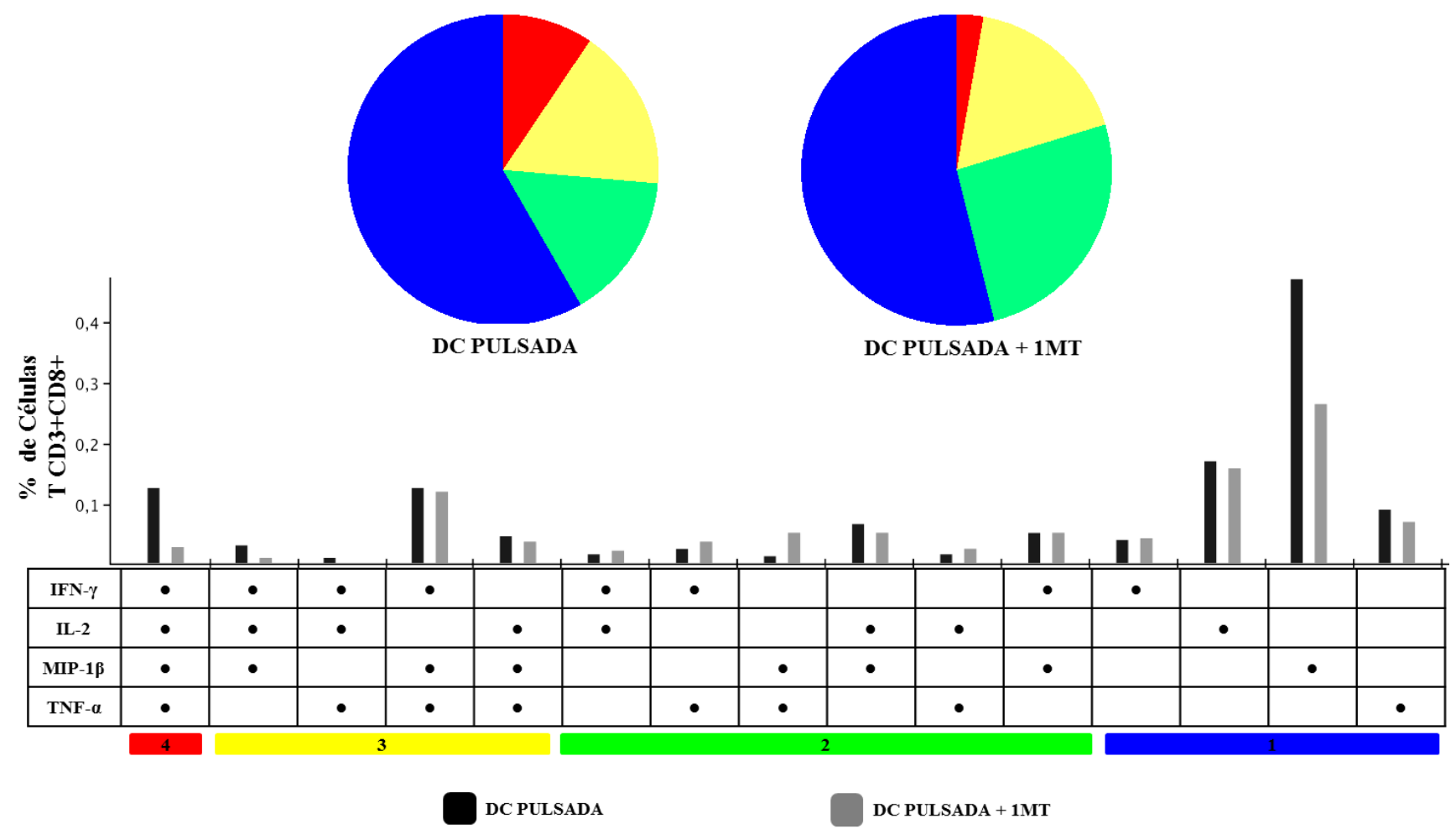

A capacidade das DCs maduras e maduras + 1MT em estimular linfócitos autólogos $\mathrm{TCD}^{+}$foi avaliada pela expressão individual e simultânea de citocinas pró-inflamatórias (IL-2, TNF- $\alpha$ e IFN- $\gamma$ ) e quimiocina (MIP-1 $\beta$ ). O diagrama de setores circulares representa a intensidade da resposta $\mathrm{T}$ celular obtida de acordo com o número de mediadores produzidos: 1 (azul), 2 (verde), 3 (amarelo) e 4 (vermelho). O gráfico de barras representa a proporção de células $\mathrm{TCD}^{+}$responsáveis pela produção desses mediadores imunológicos, de forma combinada (atividade polifuncional) ou isolada (atividade monofuncional), em cada um dos estímulos utilizados. Os gráficos em barra representam a média de 5 experimentos realizados com amostras de indivíduos HIV .

Em conjunto, esses resultados indicam que, em 96 horas de cocultivo, DCs imaturas induzem uma resposta polifuncional em uma porcentagem menor de linfócitos TCD8 ${ }^{+}$ autólogos quando comparadas as DCs ativadas, com especial destaque para DCs maduras que apresentam o melhor perfil de resposta. O pulso com HIV quimicamente inativado não foi capaz de induzir alterações no perfil de resposta gerado pelo estímulo com DCs imaturas. Em DCs maduras, o bloqueio da enzima IDO não foi capaz de induzir alterações no perfil de resposta adotado, porém nas DCs pulsadas o tratamento com 1-metil-triptofano aumentou discretamente a porcentagem de linfócitos $\mathrm{TCD}^{+}$capazes de produzir uma resposta polifuncional, embora a resposta mais potente caracterizada pela produção simultânea de 4 
mediadores imunológicos tenha sido 3 vezes maior no estímulo com DCs pulsadas na ausência de tratamento com 1-metil-triptofano. 


\section{DISCUSSÃO}

O papel que a enzima IDO exerce sobre a regulação do sistema imunológico tem sido cada vez mais relevante para a compreensão dos mecanismos envolvidos na patogênese da AIDS e para a adoção de novas medidas terapêuticas. Desse modo, o presente trabalho visa a análise dessa enzima em monócitos e células dendríticas derivadas de monócitos (MoDCs) de indivíduos infectados pelo HIV.

A técnica de citometria de fluxo foi utilizada para a análise do perfil fenotípico das células estudadas, detecção intracelular de IDO, análise de linfoproliferação e produção de citocinas pró-inflamatórias, quimiocinas e marcador de citotoxicidade por linfócitos autólogos estimulados pelas DCs. Para análise da expressão do RNAm da enzima de interesse foi utilizada a técnica de PCR em tempo real. Depois de estabelecidos os protocolos, amostras provenientes de 5 indivíduos sadios e 10 pacientes cronicamente infectados pelo HIV foram selecionadas para o desenvolvimento do trabalho.

Inicialmente procedemos à caracterização fenotípica de monócitos, células precursoras das DCs, dos dois grupos estudados, quais sejam controles e indivíduos $\mathrm{HIV}^{+}$. Os resultados referentes à população de monócitos mostraram aspectos semelhantes, principalmente pela elevada expressão dos marcadores CD14 e HLADR (58), indicando que as células precursoras de pacientes e controles apresentaram-se fenotipicamente similares quanto aos marcadores estudados. Vale destacar que a análise da intensidade de fluorescência média do marcador de coestimulação CD86 revelou um aumento significativo nos indivíduos $\mathrm{HIV}^{+}$quando comparados aos sadios, sugerindo um maior estado de ativação dessa população celular no grupo de indivíduos infectados.

Analisamos então as características fenotípicas das DCs. Tal procedimento é fundamental para análise do estado de diferenciação e maturação dessas células. Os resultados encontrados demonstraram que as DCs, tanto dos indivíduos sadios quanto dos pacientes infectados pelo HIV, apresentaram características típicas dessa população celular, principalmente pela elevada expressão de CD11c e HLADR e perda de expressão de CD14, confirmando a eficácia do processo de diferenciação a partir de monócitos (58).

Após o estímulo das DCs com HIV quimicamente inativado e/ou coquetel de citocinas pró-inflamatórias, o aspecto morfológico das células ativadas (maduras e pulsadas) se mostrou mais espraiado e fusiforme e foi corroborado com um aumento significativo na expressão dos marcadores de coestimulação CD80 e CD40, além do marcador de ativação CD83 nos grupos de indivíduos sadios e de pacientes infectados pelo HIV. 
Um aspecto interessante foi a observação de que as DCs maduras dos indivíduos sadios apresentaram níveis significativamente maiores na intensidade de fluorescência média dos marcadores HLADR e CD1a, quando comparadas às DCs maduras dos indivíduos $\mathrm{HIV}^{+}$. O mesmo aumento significativo foi observado para a intensidade de fluorescência média do marcador HLADR nas DCs pulsadas. Além disso, para o marcador CD1a esse aumento significativo ocorreu tanto em relação à porcentagem de expressão nas células analisadas, quanto em relação à intensidade de fluorescência média determinada por esse marcador.

Tanto o marcador HLADR quanto a molécula CD1a podem ser relacionados com a capacidade de apresentação antigênica altamente associada às DCs. A captura e processamento do antígeno são as etapas iniciais que permitem a indução posterior de uma resposta $\mathrm{T}$ celular específica. Primeiramente descrita em DCs da pele, a molécula CD1a intimamente relacionada a apresentação de antígenos lipídicos, vem sendo relacionada com DCs presentes em diversos locais do organismo, como pulmão e trato genital (59-61).

Em 2008, um estudo revelou que a expressão de CD1a estaria associada às DCs com alta capacidade de expressão de IL-12 e eficiente polarização de resposta T celular específica do tipo Th1 (62). Com base nisso, podemos sugerir que a diminuição na expressão do marcador CD1a e possivelmente do marcador HLADR nas DCs maduras dos indivíduos $\mathrm{HIV}^{+}$, estaria associada com uma queda na intensidade da resposta $\mathrm{T}$ celular, característica da fase crônica da infecção.

Em nossos ensaios observamos também que as DCs imaturas dos indivíduos infectados pelo HIV apresentaram níveis significativamente maiores na porcentagem de expressão dos marcadores de coestimulação CD40 e CD86, quando comparadas às DCs imaturas dos indivíduos sadios. Neste sentido, estudos indicam que o HIV induz um estado de semi-ativação nas DCs, promovendo um aumento na expressão de moléculas relacionadas à maturação dessas células ainda em seu estado basal (63).

Para uma melhor análise da capacidade do HIV quimicamente inativado em induzir alterações fenotípicas e funcionais nas DCs, uma porção dessas células geradas foi tratada somente com o vírus inativado, sem adição do coquetel de citocinas pró-inflamatórias (DCs imaturas/vírus). Além disso, para aprofundar o estudo sobre a enzima de interesse, uma porção das DCs ativadas foi tratada com $100 \mu \mathrm{M}$ de 1-metil-triptofano (1-MT), bloqueador competitivo de IDO, 24 horas antes da indução de maturação (DCs maduras/1MT e DCs pulsadas/1MT). A análise do perfil fenotípico dessas populações celulares não demonstrou diferenças significativas, indicando que, o pulso viral nas DCs imaturas e o tratamento com 1- 
metil-triptofano nas DCs ativadas não induziu alterações nos perfis de expressão de marcadores de diferenciação e ativação celular nas populações analisadas.

Com relação a análise de IDO, para a identificação desta enzima por citometria de fluxo foi necessária a marcação intracelular dos monócitos e das DCs geradas. Com base nos experimentos realizados, as DCs se mostraram muito sensíveis ao processo de fixação e permeabilização, tendo sido observado alto percentual de morte celular durante a realização dos ensaios. Assim, alguns protocolos foram testados para selecionar a técnica menos invasiva e prejudicial às DCs, mas que ao mesmo tempo garantisse a detecção da enzima de interesse.

Durante a padronização dos ensaios, utilizou-se IFN- $\gamma$ como estímulo potente para indução da expressão de IDO (57) e verificação da eficácia do processo de marcação intracelular. Observamos que com o protocolo de marcação intracelular padronizado obtivemos um aumento expressivo na indução de IDO nas DCs ativadas com IFN- $\gamma$ em diferentes concentrações e tempos de estímulo (figura 6), demonstrando a eficácia da técnica utilizada. Apesar do importante papel do IFN- $\gamma$ na indução da enzima de interesse descrita nesse trabalho, optamos por utilizar o coquetel de citocinas pró-inflamatórias descrito anteriormente para indução de maturação, a fim de estabelecer correlações entre a expressão e atividade da enzima IDO no protocolo padrão de geração de DCs como produto vacinal em desenvolvimento pelo nosso grupo de estudo.

Uma vez padronizada a técnica de marcação, passamos à análise das amostras estudadas. Constatamos que os monócitos de indivíduos $\mathrm{HIV}^{+}$e sadios apresentaram níveis semelhantes de expressão de IDO, mostrando que os precursores das DCs estudadas apresentavam a mesma condição basal.

Com relação à análise da expressão de IDO em DCs, embora não tenhamos obtido diferenças estatisticamente significativas, observamos que em DCs imaturas, os níveis de IDO encontrados foram menores do que os observados em monócitos, tanto em amostras de pacientes, quanto de controles. Após o processo de ativação DCs de indivíduos do grupo controle apresentaram níveis constantes de IDO, independente do pulso viral. Em contraste, DCs maduras e pulsadas do grupo de indivíduos $\mathrm{HIV}^{+}$apresentaram aumento significativo na expressão de IDO quando comparadas as DCs imaturas do mesmo grupo e quando comparadas aos mesmos estágios de diferenciação do grupo de indivíduos sadios.

Von Bubnoff e colaboradores demonstraram que apenas uma porção de DCs maduras é capaz de expressar IDO e que essa expressão está associada com marcadores de ativação, 
em especial a molécula CD83 (64). De fato, observamos que com o aumento significativo na expressão da molécula CD83 encontrado nas DCs ativadas em comparação com as DCs imaturas, houve uma expressão significativamente mais elevada de IDO nas DCs maduras e pulsadas no grupo de indivíduos $\mathrm{HIV}^{+}$. Embora seja importante ressaltar que, no grupo de indivíduos sadios, observamos apenas uma tendência de aumento de expressão de IDO nas DCs ativadas em relação ás imaturas, sem significância estatística.

Ainda no contexto de avaliação da expressão de IDO por citometria de fluxo, observamos que o pulso com HIV quimicamente inativado nas DCs imaturas promoveu uma tendência em aumentar os níveis de IDO, embora não tenham sido observadas diferenças significativas. Esse achado pode ser corroborado por estudos que revelam a capacidade do HIV em induzir a expressão de IDO, um processo aparentemente mediado pela produção de IFN- $\gamma$. Tais estudos ainda destacam a correlação entre o papel do vírus e ação da enzima no contexto da patogênese do HIV (49, 65-67).

1-MT é um bloqueador de IDO, competitivo e não tóxico (68), com capacidade de bloquear a indução de tolerância contra enxertos, autoantígenos e tumores (39, 69-71). Em 2012, Theodoros Eleftheriadis e colaboradores demonstraram que o uso de 1-MT era capaz de suprimir a função mitocondrial, induzir glicólise aeróbica e diminuir a produção de IL-10 por linfócitos humanos, revertendo parcialmente os efeitos da indução de IDO (72). Em nosso estudo, o tratamento com 1-MT, demonstrou uma tendência em reduzir os níveis de expressão de IDO nas DCs ativadas, principalmente nas DCs pulsadas, embora não tenham sido evidenciadas diferenças estatisticamente significantes.

Paralelamente à técnica de citometria de fluxo, avaliamos a expressão relativa do RNAm da enzima IDO por meio da técnica de PCR em tempo real. As amostras foram analisadas conforme 2 aspectos, de acordo com as etapas de diferenciação e ativação de DCs: a diferença entre os níveis de expressão nas DCs imaturas em relação aos monócitos e a diferença em DCs ativadas (maduras e pulsadas) em relação às DCs imaturas.

Corroborando os dados observados nos ensaios de citometria de fluxo, confirmamos que ocorre uma redução na expressão de RNA IDO durante o processo de diferenciação de monócitos em DCs imaturas, dada a menor expressão de RNAm de IDO em DCs imaturas.

Embora os dados da literatura ainda não sejam consistentes em relação à caracterização da enzima IDO em monócitos, nossos dados sugerem uma expressão relativamente maior do que aquela encontrada em DCs imaturas demonstrado através de duas técnicas utilizadas para identificação da enzima de interesse. Gro Furset e colaboradores 
demonstraram que monócitos são capazes de produzir a enzima IDO em resposta a ligantes de toll like receptors 7 e 8 (TLR 7 e 8) e que DCs imaturas e maduras derivadas desses monócitos produzem uma grande quantidade de citocinas, mas não são capazes de induzir a expressão de IDO em resposta aos mesmos ligantes (40). Esses dados sugerem aspectos distintos na regulação da expressão de IDO entre monócitos e DCs, assim como evidenciado em nossos resultados.

Com relação à comparação entre DCs ativadas e DCs imaturas, observamos que tanto as DCs maduras quanto as pulsadas expressam níveis relativamente maiores do RNAm de IDO, tanto no grupo de indivíduos sadios, quanto no grupo de pacientes infectados pelo HIV. Esses dados são corroborados por um estudo que revelou que as DCs imaturas não expressam o RNAm de IDO constitutivamente, mas que após processo de ativação por 24 horas, os transcritos puderam ser claramente identificados (64).

Por sua vez, a comparação entre DCs maduras do grupo controle com as do grupo de pacientes revelou um aumento não significativo na expressão no RNAm de IDO nos indivíduos $\mathrm{HIV}^{+}$, refletindo os níveis maiores de expressão da enzima IDO característica desse grupo, possivelmente devido à ativação crônica do sistema imunológico. Boasso e colaboradores obtiveram resultados semelhantes ao identificar que PBMCs de indivíduos $\mathrm{HIV}^{+}$, sob ausência ou presença de tratamento antirretroviral, apresentaram níveis significativamente maiores na expressão do RNAm de IDO quando comparadas ao grupo de indivíduos sadios (52).

Vale lembrar que as técnicas utilizadas para análise da enzima IDO, citometria de fluxo e PCR em tempo real, avaliam respectivamente a presença da enzima de interesse no citoplasma das DCs e a expressão do RNAm da IDO. A tendência de maior expressão do RNAm da enzima IDO, analisada por PCR em tempo real, nas DCs maduras dos pacientes quando comparadas ao grupo controle, foi corroborada por uma maior expressão da enzima no citoplasma das DCs analisada por citometria de fluxo. A expressão do RNAm nem sempre consiste na tradução da proteína, portanto, a comparação entre os resultados obtidos com as duas técnicas utilizadas deve levar em consideração essa questão.

Em conjunto, os resultados de identificação da enzima IDO em monócitos e em DCs de indivíduos $\mathrm{HIV}^{+}$, sugerem que as células precursoras, constituídas pelos monócitos, expressam níveis elevados de IDO e, após processo de diferenciação em DCs imaturas, esses níveis sofrem uma queda expressiva. Após processo de ativação, foi possível observar que as DCs ativadas foram capazes de elevar os níveis de IDO em relação às DCs imaturas. Observou-se também um aumento significativo na expressão de IDO nas DCs maduras e 
pulsadas do grupo de indivíduos infectados em relação aos sadios, corroborando o fato de que o vírus é capaz de induzir a expressão da enzima em células apresentadoras de antígenos.

Outro aspecto analisado em nosso trabalho foi a avaliação funcional das DCs estudadas, a fim de se estabelecer uma possível correlação com os níveis de expressão de IDO. Para tanto, realizamos ensaios de linfoproliferação e avaliação de polifuncionalidade de linfócitos autólogos estimulados com as DCs em diferentes estágios de maturação, com ou sem pulso de HIV quimicamente inativado, tratadas ou não com 1-metil-triptofano.

Os ensaios de linfoproliferação, baseados na incorporação do corante CFSE, demonstraram que as DCs em diferentes estágios de maturação foram capazes de induzir resposta proliferativa de linfócitos TCD4 e TCD8 autólogos após 24 e 96 horas de cocultivo, embora não tenham sido evidenciadas diferenças estatisticamente significativas entre as DCs imaturas, maduras e pulsadas.

Além disso, o pulso das DCs imaturas com HIV quimicamente inativado não revelou alterações no perfil de resposta encontrado. Já o tratamento com 1-metil-triptofano demonstrou uma discreta tendência de aumento de resposta linfoproliferativa induzida por DCs ativadas tanto em células TCD4, quanto TCD8 autólogas. Nesse contexto, Xiao-Li Huang e colaboradores evidenciaram que DCs pulsadas com peptídeos de HIV-1, isolados ou combinados, são capazes de melhorar a resposta proliferativa e polifuncional de linfócitos $\mathrm{TCD}^{+}$e $\mathrm{TCD}^{+}$específicos (73). Além disso, os dados existentes na literatura revelam o papel da enzima IDO na supressão da proliferação das células T e a reversão parcial desse bloqueio quando foi utilizado o bloqueador 1-metil-triptofano $(38,74-76)$.

Recentemente foi proposto que a qualidade da resposta $\mathrm{T}$ celular induzida por peptídeos derivados do HIV-1 poderia ser definida pela marcação intracelular de vários mediadores imunológicos, dentre eles, citocinas pró-inflamatórias (IFN- $\gamma$, IL-2 e TNF- $\alpha$ ), quimiocina (MIP-1 $\beta$ ) e a molécula de desgranulação citotóxica CD107a. A produção simultânea de ao menos 2 destes mediadores, denominada capacidade polifuncional, vêm sendo associada com um bom prognóstico e um melhor controle da infecção pelo HIV, e também vem sendo associada à resposta apresentada pelos controladores de elite e progressores lentos (77), constituindo desta forma um possível candidato a correlato de proteção na infecção pelo HIV.

Com relação ao estímulo de linfócitos $\mathrm{TCD}^{+}$, nossos resultados mostraram uma tendência nas DCs ativadas em induzir uma resposta polifuncional mais expressiva após 24 
horas de cocultivo quando comparadas às DCs imaturas. Após 96 h observamos uma redução no estímulo por DCs, em todos os estágios de ativação.

Observamos que o tratamento das DCs ativadas com 1MT não induziu diferenças expressivas nas coculturas estimuladas por 24h, entretanto após 96h, a intensidade da resposta polifuncional foi parcialmente recuperada, principalmente no estímulo com DCs pulsadas, sugerindo um papel importante da enzima IDO na presença do vírus, em 96 horas de cocultivo.

Existem poucas informações sobre a ação de células apresentadoras de antígenos no estímulo de uma resposta polifuncional, e não apenas proliferativa, de células T efetoras capaz de controlar a infecção pelo HIV. Nesse contexto, Sabado e colaboradores ,em 2009, sugeriram que DCs pulsadas com HIV infectante ou quimicamente inativado por AT-2 são capazes de induzir uma resposta específica in vitro, a partir de linfócitos $\mathrm{T}$ virgens de indivíduos não infectados. Nesse mesmo trabalho, DCs pulsadas com HIV-1 induziram uma resposta mais intensa de células $\mathrm{TCD}^{+}$quando comparadas as células $\mathrm{TCD} 8^{+}$. Também foi observado que DCs pulsadas com HIV-1 podem induzir a mesma resposta que surge naturalmente em pacientes infectados in vivo e os resultados demonstram que o vírus quimicamente inativado por AT-2 é uma excelente fonte de antígenos que podem ser usados num contexto de vacinação terapêutica, não apenas pela capacidade de re-estímulo de células de memória existentes, mas também por restaurar a resposta específica enfraquecida na fase aguda da infecção (78). Em conjunto, esses dados corroboram nossos resultados de resposta polifuncional mais evidente em linfócitos $\mathrm{TCD}^{+}$após 24 horas de cocultivo com DCs pulsadas com HIV quimicamente inativado. Além disso,

Em nossos ensaios, levando em consideração as diferenças encontradas entre a indução de resposta polifuncional por DCs imaturas, maduras e pulsadas foi possível observar que em 96 horas, o tratamento com 1-MT demonstrou uma tendência de aumento na polifuncionalidade de linfócitos autólogos $\mathrm{TCD}^{+}$estimulados pelas DCs pulsadas sob influência do bloqueador. Esses dados sugerem a atuação mais expressiva da enzima IDO após 96 horas de cocultivo, uma vez que, em 24 horas não foi possível observar alteração no perfil de resposta induzido pelas DCs tratadas com 1-MT.

Com relação ao estímulo de linfócitos $\mathrm{TCD}^{+}$por $\mathrm{DCs}$, encontramos um perfil diferente daquele observado para linfócitos TCD4 $4^{+}$.

Os resultados obtidos mostraram que em 24 horas de cocultivo as células TCD $8^{+}$ apresentaram uma resposta polifuncional menos potente do que a observada nas células 
$\mathrm{TCD}^{+}$no mesmo tempo de cocultivo. Além disso, apesar da resposta pouco expressiva, as DCs imaturas foram capazes de induzir uma resposta polifuncional em uma porcentagem maior de linfócitos autólogos do que as DCs ativadas. Porém, em 96 horas de cocultivo observa-se um aumento na intensidade da resposta induzida, principalmente no estímulo com DCs maduras.

Com relação ao tratamento com 1-metil-triptofano, em 24 horas não foi possível observar alterações expressivas no estímulo com DCs maduras, embora as DCs pulsadas tenham demonstrado maior tendência de indução de polifuncionalidade na ausência do bloqueador. Já em 96 horas, o bloqueador parece exercer uma influência discreta no aumento da polifuncionalidade dos linfócitos estimulados, embora a resposta mais potente ainda tenha sido observada no estímulo com DCs pulsadas na ausência de tratamento.

Os aspectos distintos encontrados entre os linfócitos $\mathrm{TCD}^{+}$e $\mathrm{TCD}^{+}$podem estar associados ao padrão de resposta encontrado em cada um desses tipos celulares. A função efetora de citotoxicidade e eliminação de células infectadas, geralmente associada a linfócitos $\mathrm{TCD}^{+}$pode não apresentar a mesma capacidade de produção de citocinas inflamatórias e recrutamento celular, comumente associada aos linfócitos $\mathrm{TCD}^{+}$. Apesar disso, o número amostral (5 indivíduos $\mathrm{HIV}^{+}$) dessa etapa do trabalho ainda não permite correlações adequadas entre os padrões de resposta encontrados.

Vale lembrar que, o pulso com HIV quimicamente inativado nas DCs imaturas foi capaz de induzir resposta polifuncional potente tanto em linfócitos $\mathrm{TCD} 4^{+}$quanto $\mathrm{TCD} 8^{+}$, chegando a níveis comparáveis ao estímulo com DCs ativadas, sugerindo que o pulso viral pode funcionar como um estímulo de maturação para indução de resposta específica pelas DCs geradas.

Sob altos índices de viremia, células TCD8 HIV específicas apresentam uma disfunção em relação à produção de citocinas (IFN- $\gamma$, IL-2 e TNF- $\alpha$ ) e potencial proliferativo. Durante o tratamento antirretroviral, a capacidade de secreção de citocinas por essas células efetoras pode ser gradualmente restaurada. Desse modo, a redução da replicação viral e, consequentemente, da exposição a antígenos circulantes in vivo, induzidas pelo tratamento antirretroviral, permite uma restauração das células $\mathrm{TCD}^{+}$com o estabelecimento de células polifuncionais. Esses achados sugerem que a carga viral plasmática exerce uma forte influência no perfil fenotípico e funcional das células TCD8 HIV específicas (79).

Células $\mathrm{T}$ vírus-específicas diferem em relação a vários parâmetros incluindo: fatores intrínsecos, como a restrição ao HLA (antígeno leucocitário humano), antígeno alvo e receptor de células $\mathrm{T}$ (TCR); e fatores ontogênicos, como a história replicativa, status de 
diferenciação e perfil de ativação. Cada um desses parâmetros afeta diretamente as propriedades das células $\mathrm{T}$ e pode influenciar no controle da infecção pelo HIV. A heterogeneidade das células TCD8 é um obstáculo importante para a elucidação da complexidade funcional dessas células no contexto da infecção e pode explicar os dados conflitantes encontrados na literatura (80).

Em nossos ensaios, levando em consideração as diferenças encontradas entre a indução de resposta polifuncional por DCs imaturas, maduras e pulsadas foi possível observar que em 96 horas, o tratamento com 1-metil-triptofano demonstra uma tendência de aumento na polifuncionalidade de linfócitos autólogos, principalmente em relação aos linfócitos TCD4 $^{+}$estimulados pelas DCs pulsadas sob influência do bloqueador em 96 horas de cocultivo.

Vale salientar que ainda que tenhamos testado várias concentrações de 1MT, não conseguimos inibir totalmente a expressão de IDO.

Considerando o tempo inicial do ensaio de cocultivo, 24 horas, observamos que neste período as células TCD4+ foram capazes de produzir uma resposta polifuncional de maior intensidade do que as células TCD8+ em relação aos mesmos estímulos. Após 96 horas de cocultivo, observou-se uma queda na intensidade da resposta TCD4. Essa queda na intensidade da resposta polifuncional pode estar associada com a ação da enzima IDO, uma vez que o tratamento das DCs ativadas com 1-metil-triptofano reverteu parcialmente a intensidade dessa resposta em células $\mathrm{TCD}^{+}$. O mesmo não foi observado nas células $\mathrm{TCD}^{+}$, uma vez que o tratamento com o bloqueador não alterou de forma expressiva o perfil de resposta adotado.

Desse modo os nossos achados sugerem que a ação da enzima IDO ocorre de maneira distinta entre linfócitos $\mathrm{TCD}^{+}$e $\mathrm{TCD}^{+}$. Nossos resultados indicam que, em 96 horas de cocultivo a influência da ação da enzima é observada apenas em linfócitos TCD4 ${ }^{+}$, o que pode ocorrer de maneira mais tardia para os linfócitos $\mathrm{TCD}^{+}$.

Os dados existentes na literatura revelam o papel da enzima IDO na supressão da proliferação das células T $(38,74-76)$, porém, a relação entre a potência da resposta induzida pelas DCs e a expressão de IDO ainda não foi claramente identificada. Os nossos dados sugerem uma relação entre a presença da enzima, atividade polifuncional de células $\mathrm{T}$ e tempo de cocultivo entre as DCs geradas e os linfócitos autólogos.

No contexto de utilização de vacinas de DCs como alternativa terapêutica ou complementar para o tratamento de pacientes infectados pelo HIV, a detecção da enzima IDO pode funcionar como marcador para caracterização do perfil das células geradas e associada 
com outros aspectos fenotípicos e funcionais, auxiliar no desenvolvimento das técnicas utilizadas. 


\section{CONCLUSÕES}

- Células precursoras (monócitos) de indivíduos sadios e de pacientes infectados pelo HIV demonstraram um perfil fenotípico e expressão da enzima IDO semelhantes, indicando que o processo de diferenciação a partir desses monócitos ou o estágio de ativação podem estar relacionados com as diferenças encontradas nas DCs geradas.

- $\quad$ As DCs ativadas (maduras e pulsadas) do grupo de indivíduos $\mathrm{HIV}^{+}$demonstram um aumento significativo na expressão da enzima IDO quando comparadas às DCs imaturas. Esses dados corroboram a ideia de que a expressão da enzima IDO ocorre após estímulo de ativação e de que o HIV é capaz de induzir a síntese dessa enzima através de mecanismos envolvidos com a proliferação desse patógeno.

- DCs em diferentes estágios de maturação são capazes de induzir resposta linfoproliferativa em 24 e 96 horas de cocultivo.

- $\quad$ Em nossos ensaios, levando em consideração as diferenças encontradas entre a indução de resposta polifuncional por DCs imaturas, maduras e pulsadas foi possível observar que em 96 horas, o tratamento com 1-metil-triptofano demonstra uma tendência de aumento na polifuncionalidade de linfócitos autólogos, principalmente em relação aos linfócitos TCD4 ${ }^{+}$estimulados pelas DCs pulsadas sob influência do bloqueador em 96 horas de cocultivo.

- $\quad$ Sugerimos que a ação da enzima IDO ocorra de maneira distinta entre linfócitos $\mathrm{TCD}^{+}$e $\mathrm{TCD}^{+}$. Em 96 horas de cocultivo a influência da ação da enzima é observada apenas em linfócitos $\mathrm{TCD}^{+}$, o que pode ocorrer de maneira mais tardia para os linfócitos $\mathrm{TCD}^{+}$. 


\section{REFERÊNCIAS*}

1. Joint United Nations Programme on HIV and AIDS (UNAIDS).[Internet]. How AIDS changed everything; [Atualizado em 24/08/2015; citado em 19/09/2015]. Disponível em: http://www.unaids.org/sites/default/files/media_asset/20150714_FS_MDG6_Report_en.pdf.

2. Barre-Sinoussi F. HIV as the cause of AIDS. Lancet. 1996;348(9019):31-5.

3. Cullen BR. Regulation of HIV-1 gene expression. FASEB Journal : official publication of the Federation of American Societies for Experimental Biology. 1991;5(10):2361-8.

4. Cullen BR, Malim MH. The HIV-1 Rev protein: prototype of a novel class of eukaryotic post-transcriptional regulators. Trends in Biochemical Sciences. 1991;16(9):34650 .

5. Levy JA. HIV and host immune responses in AIDS pathogenesis. Journal of Clinical Apheresis. 1993;8(1):19-28.

6. van Gils MJ, Edo-Matas D, Bowles EJ, Burger JA, Stewart-Jones GB, Schuitemaker H. Evolution of human immunodeficiency virus type 1 in a patient with cross-reactive neutralizing activity in serum. Journal of Virology. 2011;85(16):8443-8.

7. Engelman A, Cherepanov P. The structural biology of HIV-1: mechanistic and therapeutic insights. Nature Reviews Microbiology. 2012;10(4):279-90.

8. Brenchley JM, Ruff LE, Casazza JP, Koup RA, Price DA, Douek DC. Preferential infection shortens the life span of human immunodeficiency virus-specific CD4+ T cells in vivo. J Virol. 2006;80(14):6801-9.

9. Mocroft A, Sabin CA, Youle M, Swaden L, Tyrer M, Wilson D, et al. Changing treatment patterns among patients with HIV: Royal Free Hospital 1987-97. HIV Medicine. 1999;1(1):32-9.

10. Ledergerber B, Egger M, Opravil M, Telenti A, Hirschel B, Battegay M, et al. Clinical progression and virological failure on highly active antiretroviral therapy in HIV-1 patients: a prospective cohort study. Swiss HIV Cohort Study. Lancet. 1999;353(9156):863-8.

11. Edwards IR, Aronson JK. Adverse drug reactions: definitions, diagnosis, and management. Lancet. 2000;356(9237):1255-9.

12. Levy Y. Therapeutic HIV vaccines: an update. Curr HIV/AIDS Rep. 2005;2(1):5-9.

13. Garcia F, Leon A, Gatell JM, Plana M, Gallart T. Therapeutic vaccines against HIV infection. Human Vaccines \& Immunotherapeutics. 2012;8(5):569-81.

*De acordo com:

International Committee of Medical Journal Editors. [Internet]. Uniform requirements for manuscripts submitted to Biomedical Journal: sample references. [updated 2011 Jul 15]. Available from: http://www.icmje.org 
14. Kundu SK, Engleman E, Benike C, Shapero MH, Dupuis M, van Schooten WC, et al. A pilot clinical trial of HIV antigen-pulsed allogeneic and autologous dendritic cell therapy in HIV-infected patients. AIDS Research and Human Retroviruses. 1998;14(7):551-60.

15. Garcia F, Lejeune M, Climent N, Gil C, Alcami J, Morente V, et al. Therapeutic immunization with dendritic cells loaded with heat-inactivated autologous HIV-1 in patients with chronic HIV-1 infection. The Journal of Infectious Diseases. 2005;191(10):1680-5.

16. Connolly NC, Whiteside TL, Wilson C, Kondragunta V, Rinaldo CR, Riddler SA. Therapeutic immunization with human immunodeficiency virus type 1 (HIV-1) peptideloaded dendritic cells is safe and induces immunogenicity in HIV-1-infected individuals. Clinical and Vaccine Immunology : CVI. 2008;15(2):284-92.

17. Ide F, Nakamura T, Tomizawa M, Kawana-Tachikawa A, Odawara T, Hosoya N, et al. Peptide-loaded dendritic-cell vaccination followed by treatment interruption for chronic HIV-1 infection: a phase 1 trial. Journal of Medical Virology. 2006;78(6):711-8.

18. Gandhi RT, O'Neill D, Bosch RJ, Chan ES, Bucy RP, Shopis J, et al. A randomized therapeutic vaccine trial of canarypox-HIV-pulsed dendritic cells vs. canarypox-HIV alone in HIV-1-infected patients on antiretroviral therapy. Vaccine. 2009;27(43):6088-94.

19. Routy JP, Boulassel MR, Yassine-Diab B, Nicolette C, Healey D, Jain R, et al. Immunologic activity and safety of autologous HIV RNA-electroporated dendritic cells in HIV-1 infected patients receiving antiretroviral therapy. Clinical Immunology. 2010;134(2):140-7.

20. Garcia F, Climent N, Assoumou L, Gil C, Gonzalez N, Alcami J, et al. A therapeutic dendritic cell-based vaccine for HIV-1 infection. The Journal of Infectious Diseases. 2011;203(4):473-8.

21. Lu W, Arraes LC, Ferreira WT, Andrieu JM. Therapeutic dendritic-cell vaccine for chronic HIV-1 infection. Nature Medicine. 2004;10(12):1359-65.

22. Banchereau J, Steinman RM. Dendritic cells and the control of immunity. Nature. 1998;392(6673):245-52.

23. Figdor CG, de Vries IJ, Lesterhuis WJ, Melief CJ. Dendritic cell immunotherapy: mapping the way. Nature Medicine. 2004;10(5):475-80.

24. Chambers CA. The expanding world of co-stimulation: the two-signal model revisited. Trends in Immunology. 2001;22(4):217-23.

25. Steinman RM, Nussenzweig MC. Avoiding horror autotoxicus: the importance of dendritic cells in peripheral $\mathrm{T}$ cell tolerance. Proceedings of the National Academy of Sciences of the United States of America. 2002;99(1):351-8.

26. Gallucci S, Lolkema M, Matzinger P. Natural adjuvants: endogenous activators of dendritic cells. Nature Medicine. 1999;5(11):1249-55. 
27. Vermi W, Bonecchi R, Facchetti F, Bianchi D, Sozzani S, Festa S, et al. Recruitment of immature plasmacytoid dendritic cells (plasmacytoid monocytes) and myeloid dendritic cells in primary cutaneous melanomas. The Journal of Pathology. 2003;200(2):255-68.

28. Paquette RL, Hsu NC, Kiertscher SM, Park AN, Tran L, Roth MD, et al. Interferonalpha and granulocyte-macrophage colony-stimulating factor differentiate peripheral blood monocytes into potent antigen-presenting cells. J Leukoc Biol. 1998;64(3):358-67.

29. Sallusto F, Lanzavecchia A. Mobilizing dendritic cells for tolerance, priming, and chronic inflammation. The Journal of Experimental Medicine. 1999;189(4):611-4.

30. Munn DH, Mellor AL. Indoleamine 2,3 dioxygenase and metabolic control of immune responses. Trends in Immunology. 2013;34(3):137-43.

31. Munn DH, Shafizadeh E, Attwood JT, Bondarev I, Pashine A, Mellor AL. Inhibition of $\mathrm{T}$ cell proliferation by macrophage tryptophan catabolism. The Journal of Experimental Medicine. 1999;189(9):1363-72.

32. Peters JC. Tryptophan nutrition and metabolism: an overview. Advances in Experimental Medicine and Biology. 1991;294:345-58.

33. Higuchi K, Hayaishi O. Enzymic formation of D-kynurenine from D-tryptophan. Arch Biochem Biophys. 1967;120(2):397-403.

34. Taylor MW, Feng GS. Relationship between interferon-gamma, indoleamine 2,3dioxygenase, and tryptophan catabolism. The FASEB journal : official publication of the Federation of American Societies for Experimental Biology. 1991;5(11):2516-22.

35. Grohmann U, Fallarino F, Puccetti P. Tolerance, DCs and tryptophan: much ado about IDO. Trends in Immunology. 2003;24(5):242-8.

36. Terness P, Bauer TM, Rose L, Dufter C, Watzlik A, Simon H, et al. Inhibition of allogeneic $\mathrm{T}$ cell proliferation by indoleamine 2,3-dioxygenase-expressing dendritic cells: mediation of suppression by tryptophan metabolites. The Journal of Experimental Medicine. 2002;196(4):447-57.

37. Frumento G, Rotondo R, Tonetti M, Damonte G, Benatti U, Ferrara GB. Tryptophanderived catabolites are responsible for inhibition of $\mathrm{T}$ and natural killer cell proliferation induced by indoleamine 2,3-dioxygenase. The Journal of Experimental Medicine. 2002;196(4):459-68.

38. Mellor AL, Munn DH. Tryptophan catabolism and T-cell tolerance: immunosuppression by starvation? Immunology Today. 1999;20(10):469-73.

39. Munn DH, Zhou M, Attwood JT, Bondarev I, Conway SJ, Marshall B, et al. Prevention of allogeneic fetal rejection by tryptophan catabolism. Science. 1998;281(5380):1191-3. 
40. Furset G, Floisand Y, Sioud M. Impaired expression of indoleamine 2, 3-dioxygenase in monocyte-derived dendritic cells in response to Toll-like receptor-7/8 ligands. Immunology. 2008;123(2):263-71.

41. Sim SH, Ahn YO, Yoon J, Kim TM, Lee SH, Kim DW, et al. Influence of chemotherapy on nitric oxide synthase, indole-amine-2,3-dioxygenase and CD124 expression in granulocytes and monocytes of non-small cell lung cancer. Cancer Sci. 2012;103(2):15560 .

42. Fauci AS. Host factors and the pathogenesis of HIV-induced disease. Nature. 1996;384(6609):529-34.

43. Fahey JL, Taylor JM, Manna B, Nishanian P, Aziz N, Giorgi JV, et al. Prognostic significance of plasma markers of immune activation, HIV viral load and CD4 T-cell measurements. AIDS. 1998;12(13):1581-90.

44. Liu Z, Cumberland WG, Hultin LE, Kaplan AH, Detels R, Giorgi JV. CD8+ Tlymphocyte activation in HIV-1 disease reflects an aspect of pathogenesis distinct from viral burden and immunodeficiency. Journal of acquired immune deficiency syndromes and human retrovirology : official publication of the International Retrovirology Association. 1998;18(4):332-40.

45. Sabin CA, Devereux H, Phillips AN, Janossy G, Loveday C, Lee CA. Immune markers and viral load after HIV-1 seroconversion as predictors of disease progression in a cohort of haemophilic men. AIDS. 1998;12(11):1347-52.

46. Brenchley JM, Price DA, Douek DC. HIV disease: fallout from a mucosal catastrophe? Nature Immunology. 2006;7(3):235-9.

47. Grant RS, Naif H, Thuruthyil SJ, Nasr N, Littlejohn T, Takikawa O, et al. Induction of indolamine 2,3-dioxygenase in primary human macrophages by human immunodeficiency virus type 1 is strain dependent. Journal of Virology. 2000;74(9):4110-5.

48. Widner B, Weiss G, Fuchs D. Tryptophan degradation to control T-cell responsiveness. Immunology Today. 2000;21(5):250.

49. Planes R, Bahraoui E. HIV-1 Tat protein induces the production of IDO in human monocyte derived-dendritic cells through a direct mechanism: effect on $\mathrm{T}$ cells proliferation. PloS One. 2013;8(9):e74551.

50. Zangerle R, Widner B, Quirchmair G, Neurauter G, Sarcletti M, Fuchs D. Effective antiretroviral therapy reduces degradation of tryptophan in patients with HIV-1 infection. Clinical Immunology. 2002;104(3):242-7.

51. Chen J, Shao J, Cai R, Shen Y, Zhang R, Liu L, et al. Anti-retroviral therapy decreases but does not normalize indoleamine 2,3-dioxygenase activity in HIV-infected patients. PloS One. 2014;9(7):e100446. 
52. Boasso A, Herbeuval JP, Hardy AW, Anderson SA, Dolan MJ, Fuchs D, et al. HIV inhibits CD4+ T-cell proliferation by inducing indoleamine 2,3-dioxygenase in plasmacytoid dendritic cells. Blood. 2007;109(8):3351-9.

53. Livak KJ, Schmittgen TD. Analysis of relative gene expression data using real-time quantitative PCR and the 2(-Delta Delta C(T)) Method. Methods. 2001;25(4):402-8.

54. Obermajer N, Svajger U, Jeras M, Sattin S, Bernardi A, Anderluh M. An assay for functional dendritic cell-specific ICAM-3-grabbing nonintegrin (DC-SIGN) inhibitors of human dendritic cell adhesion. Analytical Biochemistry. 2010;406(2):222-9.

55. Roederer M, Nozzi JL, Nason MC. SPICE: exploration and analysis of postcytometric complex multivariate datasets. Cytometry Part A : the journal of the International Society for Analytical Cytology. 2011;79(2):167-74.

56. Lugli E, Roederer M, Cossarizza A. Data analysis in flow cytometry: the future just started. Cytometry Part A : the journal of the International Society for Analytical Cytology. 2010;77(7):705-13.

57. Heitger A. Regulation of expression and function of IDO in human dendritic cells. Current Medicinal Chemistry. 2011;18(15):2222-33.

58. Guilliams M, Ginhoux F, Jakubzick C, Naik SH, Onai N, Schraml BU, et al. Dendritic cells, monocytes and macrophages: a unified nomenclature based on ontogeny. Nature Reviews Immunology. 2014;14(8):571-8.

59. Prakash M, Kapembwa MS, Gotch F, Patterson S. Chemokine receptor expression on mucosal dendritic cells from the endocervix of healthy women. The Journal of Infectious Diseases. 2004;190(2):246-50.

60. van Haarst JM, Verhoeven GT, de Wit HJ, Hoogsteden HC, Debets R, Drexhage HA. CD1a+ and CD1a- accessory cells from human bronchoalveolar lavage differ in allostimulatory potential and cytokine production. American Journal of Respiratory cell and Molecular Biology. 1996;15(6):752-9.

61. Masten BJ, Olson GK, Tarleton CA, Rund C, Schuyler M, Mehran R, et al. Characterization of myeloid and plasmacytoid dendritic cells in human lung. Journal of Immunology. 2006;177(11):7784-93.

62. Cernadas M, Lu J, Watts G, Brenner MB. CD1a expression defines an interleukin-12 producing population of human dendritic cells. Clinical and Experimental Immunology. 2009;155(3):523-33.

63. Schmidt B, Fujimura SH, Martin JN, Levy JA. Variations in plasmacytoid dendritic cell (PDC) and myeloid dendritic cell (MDC) levels in HIV-infected subjects on and off antiretroviral therapy. Journal of Clinical Immunology. 2006;26(1):55-64.

64. Von Bubnoff D, Scheler M, Wilms H, Fimmers R, Bieber T. Identification of IDOpositive and IDO-negative human dendritic cells after activation by various proinflammatory stimuli. Journal of Immunology. 2011;186(12):6701-9. 
65. Grant RS, Naif H, Thuruthyil SJ, Nasr N, Littlejohn T, Takikawa O, et al. Induction of indolamine 2,3-dioxygenase in primary human macrophages by human immunodeficiency virus type 1 is strain dependent. Journal of Virology. 2000;74(9):4110-5.

66. Widner B, Weiss G, Fuchs D. Tryptophan degradation to control T-cell responsiveness. Immunology Today. 2000;21(5):250.

67. Zangerle R, Widner B, Quirchmair G, Neurauter G, Sarcletti M, Fuchs D. Effective antiretroviral therapy reduces degradation of tryptophan in patients with HIV-1 infection. Clinical Immunology. 2002;104(3):242-7.

68. Jia L, Schweikart K, Tomaszewski J, Page JG, Noker PE, Buhrow SA, et al. Toxicology and pharmacokinetics of 1-methyl-d-tryptophan: absence of toxicity due to saturating absorption. Food and chemical toxicology : an international journal published for the British Industrial Biological Research Association. 2008;46(1):203-11.

69. Alexander AM, Crawford M, Bertera S, Rudert WA, Takikawa O, Robbins PD, et al. Indoleamine 2,3-dioxygenase expression in transplanted NOD Islets prolongs graft survival after adoptive transfer of diabetogenic splenocytes. Diabetes. 2002;51(2):356-65.

70. Sakurai K, Zou JP, Tschetter JR, Ward JM, Shearer GM. Effect of indoleamine 2,3dioxygenase on induction of experimental autoimmune encephalomyelitis. Journal of Neuroimmunology. 2002;129(1-2):186-96.

71. Uyttenhove C, Pilotte L, Theate I, Stroobant V, Colau D, Parmentier N, et al. Evidence for a tumoral immune resistance mechanism based on tryptophan degradation by indoleamine 2,3-dioxygenase. Nature Medicine. 2003;9(10):1269-74.

72. Eleftheriadis T, Pissas G, Karioti A, Antoniadi G, Liakopoulos V, Dafopoulou K, et al. The indoleamine 2,3-dioxygenase inhibitor 1-methyl-tryptophan suppresses mitochondrial function, induces aerobic glycolysis and decreases interleukin-10 production in human lymphocytes. Immunological Investigations. 2012;41(5):507-20.

73. Huang XL, Fan Z, Borowski L, Rinaldo CR. Multiple T-cell responses to human immunodeficiency virus type 1 are enhanced by dendritic cells. Clinical and Vaccine Immunology : CVI. 2009;16(10):1504-16.

74. Terness P, Bauer TM, Rose L, Dufter C, Watzlik A, Simon H, et al. Inhibition of allogeneic $\mathrm{T}$ cell proliferation by indoleamine 2,3-dioxygenase-expressing dendritic cells: mediation of suppression by tryptophan metabolites. The Journal of Experimental Medicine. 2002;196(4):447-57.

75. Frumento G, Rotondo R, Tonetti M, Damonte G, Benatti U, Ferrara GB. Tryptophanderived catabolites are responsible for inhibition of $\mathrm{T}$ and natural killer cell proliferation induced by indoleamine 2,3-dioxygenase. The Journal of Experimental Medicine. 2002;196(4):459-68.

76. Mellor AL, Munn DH. Tryptophan catabolism and T-cell tolerance: immunosuppression by starvation? Immunology Today. 1999;20(10):469-73. 
77. Betts MR, Nason MC, West SM, De Rosa SC, Migueles SA, Abraham J, et al. HIV nonprogressors preferentially maintain highly functional HIV-specific CD8+ T cells. Blood. 2006;107(12):4781-9.

78. Lubong Sabado R, Kavanagh DG, Kaufmann DE, Fru K, Babcock E, Rosenberg E, et al. In vitro priming recapitulates in vivo HIV-1 specific $\mathrm{T}$ cell responses, revealing rapid loss of virus reactive CD4 T cells in acute HIV-1 infection. PloS One. 2009;4(1):e4256.

79. Rehr M, Cahenzli J, Haas A, Price DA, Gostick E, Huber M, et al. Emergence of polyfunctional CD8+ T cells after prolonged suppression of human immunodeficiency virus replication by antiretroviral therapy. J Virol. 2008;82(7):3391-404.

80. Almeida JR, Sauce D, Price DA, Papagno L, Shin SY, Moris A, et al. Antigen sensitivity is a major determinant of CD8+ T-cell polyfunctionality and HIV-suppressive activity. Blood. 2009;113(25):6351-60. 
APÊNDICE - Cinética para determinação dos tempos de cocultivo
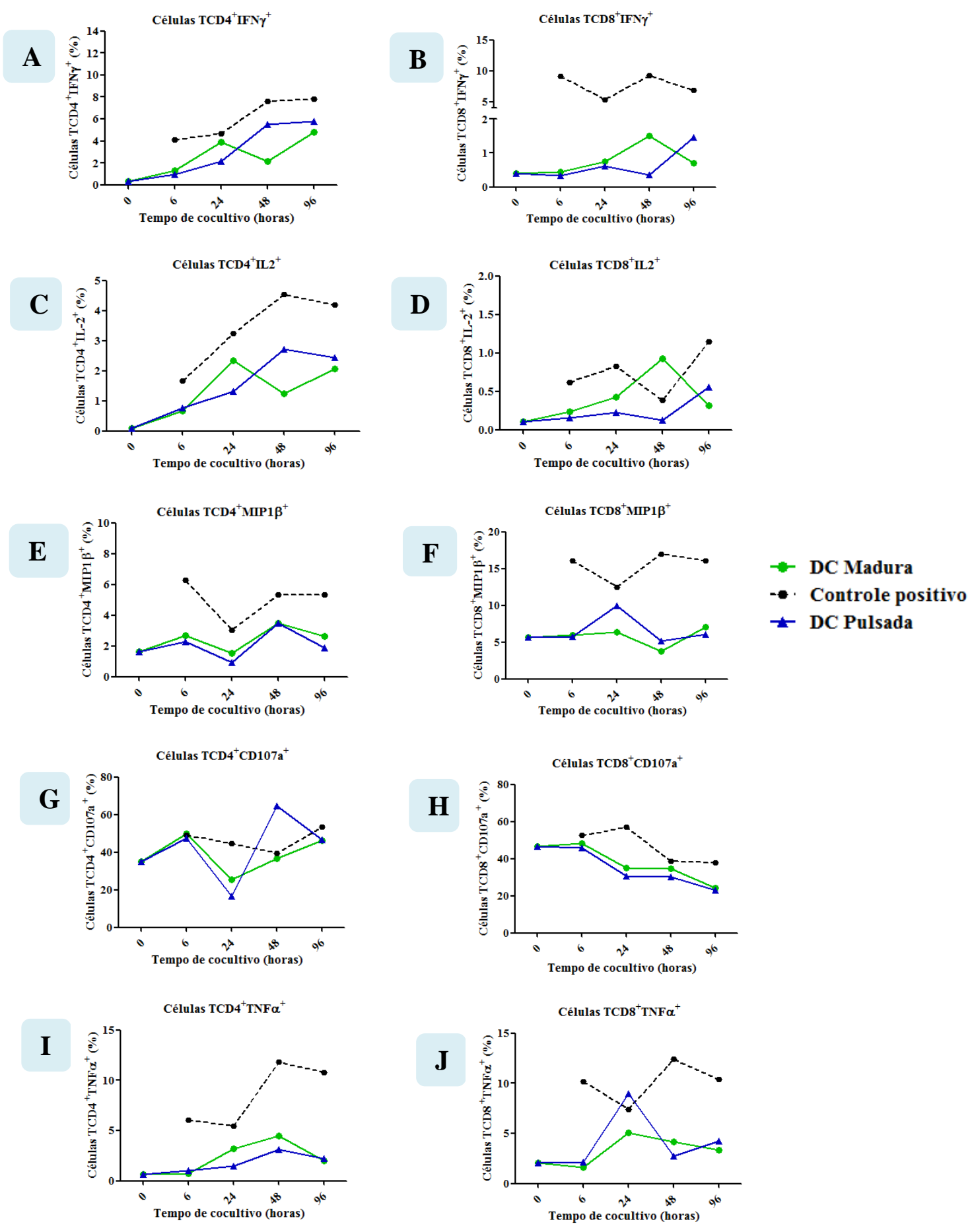

DCs pulsadas com HIV quimicamente inativado foram cocultivadas com linfócitos autólogos provenientes de indivíduo infectado pelo HIV por 6, 24, 48 e 96 horas para determinação dos tempos de indução individual de cada um dos mediadores imunológicos estudados. Os gráficos a esquerda representam a produção de IFN- $\gamma$ (A), IL-2 (C), MIP-1 $\beta$ (E), CD107a (G) e TNF- $\alpha$ (I) em linfócitos TCD4 ${ }^{+}$. Os gráficos a direita representam a produção de IFN- $\gamma(\mathrm{B})$, IL-2 (D), MIP-1 $\beta$ (F), CD107a (H) e TNF- $\alpha$ (J) em linfócitos TCD8 ${ }^{+}$. 